BNL- 66583

Informal Report

\title{
MEASUREMENTS OF THE CONFINEMENT \\ LEAKTIGHTNESS AT THE \\ KOLA NUCLEAR POWER STATION (UNIT 2) \\ IN RUSSIA
}

G.A. Greene and J.G. Guppy

August 1998

Department of Advanced Technology

Brookhaven National Laboratory

Upton, Long Island, New York 11973 
BNL- 66583

Informal Report

\title{
MEASUREMENTS OF THE CONFINEMENT LEAKTIGHTNESS AT THE KOLA NUCLEAR POWER STATION (UNIT 2) IN RUSSIA
}

\author{
G.A. Greene and J.G. Guppy
}

August 1998

\author{
Department of Advanced Technology \\ Brookhaven National Laboratory \\ Brookhaven Science Associates \\ Upton, Long Island, New York 11973 \\ Under Contract No. DE-AC02-98CH10886 \\ UNITED STATES DEPARTMENT OF ENERGY
}

*This work was performed under the auspices of the U.S. Department of Energy 


\section{Table of Contents}

\section{Final Report, Kola Confinement Leaktightness}

\section{Attachments:}

1. Project Work Plan, WBS Number 1.2.2.1., Revision 1, January 25, 1996, Project Title: Kola Confinement Leaktightness.

2. Foreign Travel Trip Report of G.A. Greene, 5/24-30, 1996 to Kola Nuclear Power Plant, Polyarnie Zori, Russia.

3. Foreign Travel Trip Report of G.A. Greene, 10/11-19, 1996 to Kola Nuclear Power Plant, Polyarnie Zori, Russia.

4. Kola Nuclear Power Plant Procedural Guide for Confinement Leaktightness Testing.

5. Results of Leaktightness Testing for Kola Unit 2 (5/96) (English and Russian).

6. Results of Leaktightness Testing for Kola Unit 1 (10/96) (English and Russian).

7. Request for Additional Material for Leaktightness Improvements, Kola Units 1, 2 (English and Russian).

8. Request from Kola NPP to B\&R for Manual Isolation Valves, Kola Unit 2 (English and Russian). 


\title{
Final Report \\ Kola Confinement Leaktightness \\ WBS Number: 1.2.2.1 \\ For the Kola Nuclear Power Plant, Polyarnie Zori, Russia
}

by

\author{
James G. Guppy \\ Principal Investigator \\ Brookhaven National Laboratory \\ Upton, NY 11973-5000 \\ 516-344-2698
}

This is the final report on the INSP project entitled, "Kola Confinement Leaktightness" conducted by BNL under the authorization of Project Work Plan WBS 1.2.2.1. This project was initiated in February 1993 to assist the Russians to reduce risks associated with the continued operation of older Soviet-designed nuclear power plants, specifically the Kola VVER-440/230 Units 1 and 2, through upgrades in the confinement performance to reduce the uncontrolled leakage rate.

The major technical objective of this project was to improve the leaktightness of the Kola NPP VVER confinement boundaries, through the application of a variety of sealants to penetrations, doors and hatches, seams and surfaces, to the extent that current technology permitted. A related objective was the transfer, through training of Russian staff, of the materials application procedures to the staff of the Kola NPP.

This project was part of an overall approach to minimizing uncontrolled releases from the Kola NPP VVER-440/230's in the event of a serious accident, and to thereby significantly mitigate the consequences of such an accident. The U.S. provided materials, application technology, and applications equipment for application of sealant materials, surface coatings, potting materials and gaskets, to improve the confinement leaktightness of the Kola VVER$440 / 230$ 's. The U.S. provided for training of Russian personnel in the applications technology. 
Under this project, with the help of US-supplied materials and equipment, the Russian workers were to seal Cable Penetrations, Doors and Hatch Covers, Liner Weld Seams, and Stem Penetrations in the confinement of Kola Units 1 and 2. The Russian workers were to also apply surface coatings to all internal compartment surfaces consisting of floors, walls and ceilings in these confinements.

The tasks and sub-tasks accomplished as part of this activity are described briefly below:

1. Project planning. This task consists of several sub-tasks:

(i) Prepare Project/Task Information Sheet. The "Kola Confinement Leaktightness” Near Term Risk Reduction Project originated in February 1993 with the issuance of the Project/Task Information Sheet and subsequent approval by the Expert Working Group.

(ii) Final Project Definition and Preparation of the Project Work Plan. The original draft Project/Task Information Sheet document was revised in October, 1993. This document defined the tasks which would be performed in order to improve the leaktightness of Kola Unit 2.

2. Negotiate and award contract for materials, equipment, test application and training.

The specifications for the materials, applications technology and training were developed between February 1993 and June 1993. The BNL Specification for the work was issued in a Request for Proposals in June 1993. The contract for the work was issued to Promatec in July 1993. This contract provided for materials, applications technology and training for a test application of the sealant to the Instrument and Control compartments in Kola Unit 2. 
3. Test application of sealant materials and delivery of materials and equipment to Kola NPP. The test application of sealant to improve the leaktightness of the I \& $C$ compartments at Kola Unit 2 was performed during August and September 1993. A leaktightness test of the two compartments was carried out, and was judged successful. The material was judged suitable for completion of application at Unit 2. Following this demonstration, the contract for delivery of sealant materials, equipment, training, and technical support to Kola NPP for the completion of the leaktightness task at Unit 2 was awarded to Promatec, and the materials and equipment needed to complete the leaktightness improvements were delivered to the Kola NPP. The Russian workers were trained in the materials application technology to continue the work at the plant.

4. Sealant/gasket installations in Kola Unit 2. Application of the sealants and gasket materials in Kola Unit 2 were begun during plant outages in the time period from August 1994 to December 1994. Additional gasket material requested by Kola NPP was ordered and delivered. The installation of gaskets and application of the sealant were completed by May 1996.

5. Confinement inspection and integrated pressure test of confinement. Inspection of sealed surfaces after exposure to confinement conditions subsequent to plant operations was conducted in the Spring of 1996. A plan for the confinement pressure test was developed by Kola NPP and reviewed and approved by BNL. An integrated pressure test of the effectiveness of the sealant and gasket applications was performed on the Unit 2 confinement in May 1996 and a test of the Unit 1 confinement was performed in November 1996. Copies of the integrated leaktightness tests for both units are included in the attachments to this report. 
A listing of the deliverables accomplished under this task are listed below. All of the deliverables below and the project milestones in the Project Work Plan have been accomplished, in spite of customs difficulties and scheduling delays with the Kola NPP plant staff.

1. Deliver sealant materials and application equipment to Kola NPP.

2. Train the Russian personnel in materials applications technology.

3. Provide a test application of sealant materials to the I\&C compartment of Kola Unit 2.

4. Complete the application of sealants to penetrations and surfaces and the installation of gaskets as identified in Project Information Sheet for the Kola Unit 2.

5. Inspect the seals at Kola NPP after exposure to plant operations.

6. Report on the pressure tests of the confinements of Kola Units 1 and 2.

There are eight attachments to this report, the Project Work Plan which documents the authorization basis for the project (Attachment 1), two reports in the form of Foreign Travel Trip Reports by G. A. Greene (BNL) for on-site evaluation of the progress of the leaktightness project at the Kola NPP (Attachments 2,3), the approved Kola NPP procedural guide for confinement leaktightness testing (Attachment 4, translated to English), the Kola NPP reports on the leaktightness results for both Kola Unit 1 and 2 (Attachments 5,6, in Russian and translated to English), a written request by the Kola NPP management for additional materials to further improve leaktightness in Units 1 and 2 (Attachment 7, in Russian and translated to English), and a written request to Burns and Roe for two manual isolation valves for Kola Unit 2 to supplement the automatic isolation valves already installed (Attachment 8, in Russian and translated to English). Attachments 7 and 8 represent unresolved action items which require resolution. Action is underway by BNL to resolve these requests to the mutual satisfaction of the DOE and Kola NPP. 


\section{ATTACHMENTS}

1. Project Work Plan, WBS Number 1.2.2.1, Revision 1, January 25, 1996, Project Title: Kola Confinement Leaktightness.

2. Foreign Travel Trip Report of G.A. Greene, 5/24-30, 1996 to Kola Nuclear Power Plant, Polyarnie Zori, Russia.

3. Foreign Travel Trip Report of G.A. Greene, 10/11-19, 1996 to Kola Nuclear Power. Plant, Polyarnie Zori, Russia.

4. Kola Nuclear Power Plant Procedural Guide for Confinement Leaktightness Testing.

5. Results of Leaktightness Testing for Kola Unit 2 (5/96) (English and Russian).

6. Results of Leaktightness Testing for Kola Unit 1 (10/96) (English and Russian).

7. Request for Additional Material for Leaktightmess Improvements, Kola Units 1, 2 (English and Russian).

8. Request from Kola NPP to B\&R for Manual Isolation Valves, Kola Unit 2 (English and Russian). 


\section{ATTACHMENT 1}

Project Work Plan

WBS Number 1.2.2.1, Revision 1

January 25, 1996

Project Title: Kola Confinement Leaktightness 


\title{
Project Work Plan
}

\author{
WBS Number: 2.2 .1 \\ Revision 1 \\ January 25, 1996
}

1. Project Title:

2. Responsibie Contractor:

3. Responsible Individual:

1. Total Estimated Cost:

5. Host Organization/

Primary Contacts:

\author{
Kola Confinement Leaktightmess \\ Brookhaven National Laboratory (BNI) \\ James G. Guppy/T. Ginsberg \\ $\$ 876 \mathrm{~K}$ (US Contribution)
}

Kola Nuclear Power Plant; Rosenergoatom

\section{Technical Objective:}

The major objective of this project is to improve the leakrighmess of the Kola Unit 2 VVER confinement boundaries, through the application of a variety of sealants to penetrations, doors and hatches, seams and surfaces, to the extent that current technology permits. A related objective is the transfer, through training of Russian staff, of the materials application rechnology to Kola NPP.

\section{Scope:}

This project is part of an overall approach to minimizing uncontrolled releases from the Kola NPP Unit 2 VVER $-440 / 230$ in the event of a serious accident, and thereby significantly mitigate the consequences of such an accident. The U.S. will provide materials, application technology, and applications equipment for application of sealant materials, surface coatings, poring materials and gaskets, to improve the confinement leaktightness of the Kola Unit 2. The U.S. will also provide for training of Russian personnel in the applicarions technology. Under this project, with the help of US supplied materials and equipment, the Russian workers will seal Cable Penerrations, Doors and Harch Covers, Liner Weld Seams, and Stem Penetrations in the confinement of Kola Unit 2. The Russian workers will also apply surface coarings to all internal comparment surfaces consisting of floors, walls and ceilings in this confinement.

\section{Description of Activities:}

(a) Project Planning. This task consists of several sub-tasks as outlined below:

(i) Prepare draft Project/Task Information Sheet. The "Kola Confinement Leakrighmess" Near Term Risk Recuction Project originated in February 1993, with the issuance of the Project/Task Information Sheet on February 24, 1993. This project definition was subsequently approved by the Expert Working Group for this work.

(ii) Final Project Definition. The original draft "Project/Task Information Sheet" document was revised on October 18, 1993. This document defined the tasks which would be performed in order to improve the leaktightmess of Kola Unit 2.

(iii) Prepare the Project Work Plan. Updating of the Project Work Plan will be done, if 
necessary, because of cost. schedule or scope of work changes.

(b) Negotiate and award contract for materials. equipment, test application and training. The specifications for the materials, applications technology and training were developed berween February 1993 and June 1993. The BNL Specification for the work was issued in a Request for Proposals in June 1993. The contract for the work was issued to Promatec in July 1993. This contract provided for materials, applications technology and training for a test application of the sealant to the Instrument and Control comparments in Kola Unit 2.

(c) Test Application of Sealant Marerials and delivery of materials and equipment to Kola NPP. The test application of sealant to improve the leakrighmess of the I \& C comparments at Kola Unit 2 was pertiormed during August and September 1993. A leak tighness test of the two cormparments was carried out, and was judged successful. The material was judged suitable for cornpletion of application at Unit 2. Russian workers were trained as applicators to continue the work at the plant.

(d) Award contract for delivery of sealant materials, equipment, training, and technical support to Kola NPP for the completion of the leakrighmess task at Unit 2. This contract was awarded only after successful complecion of Task (c) above.

(e) Delivery of materials and equipment to Kola NPP.

(f) Training of Russian workers in the materiais application technology.

(g) SealandGasket Installations in Kola Unit 2. Application of the sealants and gasket materials to Kola Unit 2 were performed during plant outages in the time period from August 1994 to December 1994. Substantial work still remains to be performed. Completion of sealant applications, except for the spare penetrations, is expected to be completed by the Kola NPP during the next plant outage.

(b) Order and deliver any additional materials and equipment that may be needed for compietion of the leakrighmess project. Additional gasket material requested by Kola NPP is sehectuled to be ordered during February 1996. When the NPP is ready for the integral leak test of the confinement, it is likely that they may request additional test equipment.

(i) Confinement Inspection and Pressure Test. This task consists of several sub-tasks as outlined below:

(i) Inspection of Seals. Inspection of sealed surfaces after exposure to confinement: conditions subsequent to plant operations will take place during the next planned outage, scheduled for late Summer 1996. A site visir by Promatec, BNL, the NPP staff, and pertaps others, featuring an inspection will be planned, and a report will be issued which documents the condition of the seaiant materials in sin after exposure to plant conditions for one year.

(ii) Planning for the Confinement pressure test will be performed by Kola NPP, and this plan will be reviewed by $\mathrm{BNL}$.

(iii) Pressure Test of Confinement. An integrated pressure rest of the effectiveness of the sealant and gasket applications will be performed on the confinement, or on selected rooms of the confinement. 
(j) Provide on-call assistance and problem resolution based on requests from DOE, Kola NPP, PNNI, and the Contractor. These include: (a) A draft report on "Kola Confinement Leakrighmess Projeci: Response to Empressarios Agrupadaos Report" - issued on July 31, 1995, and (b) a "white-paper" on the "Confinement Leaktighmess Programs for the Russian NPPs" - currently in progress.

\section{Deliverables:}

(a) Deliver sealant materials and application equipment to Kola NPP.

(b) Russian personnel trained in marerials applications technology.

(c) Provide a test application of sealant materials to the I\&C comparment of Kola Unit 2.

(d) Completed application of sealants to penerrations and surfaces, and installation of gaskets, as identified in Project Information Sheet for the Kola Unit 2.

(e) Report from Promatec summarizing sealant application work performed on Kola Unit 2.

(f) A report on the inspection of seals at Kola Unit 2 after exposure to plant operations.

(g) A report on the Pressure Tests of the confinement of Kola Unir 2.

\section{Project Schedule Milestones:}

(a) Prepare draft Project/Task Information Sheet

24FEB1993

(b) Award contract for test application in I\&C comparments

$30 \pi$ R1993

(c) Complete test application of sealant materials to the I\&C compartment of Kola Unit 2.

15SEP1993

(d) Complete Project/Task Information Sheet (Project Definition)

$180 C T 1993$

(e) Award contract for materials, equipment, and training.

21ЛI1994

(f) Delivery of sealant materials and application equipment to Kola NPP.

15AUG1994

(g) Complete training of Russian personnel in materials application technology.

$30 S E P 1994$

(h) Complete application of sealants to penetrations and surfaces, and installation of gaskets, for the Kola Unit 2.

30AUG1996

(i) Inspection of sealed surfaces after exposure to confinement condirions during plant operations.

23SEP1996

(j) Pressure Test of Confinement.

30 SEP 1996

(k) Project Complete

$30 S E P 1996$

Please see the attached Gant char. 


\section{Period of Performance:}

February 24, 1993 through September 30, 1996.

\section{Time Phased Budget:}

Please see the anached time-phased budget sheet.

13. Materials, Supplies, and Subcontracts:

Contracts for the sealant materials, applications equipment, a test application of the sealant to the Instrument and Control compartments in Kola Linit 2. and training of the Russian workers in materials application technology were issued to Promatec. Additional materials will be purchased from other vendors.

\section{Parmer Country Contribution:}

The Kola NPP will provide staff for implementation of this project. This includes seaff for interaction with the US side and Contractor, personnel to be trained in the materials application technology that will perform the actual task of sealing the confinement, and the supervisory staff. The NPP is also responsible for actual installation of sealant materials, and for providing any materials or equipment that is not provided by the US side.

\section{Notes and Contingencies:}

Since this project is a cooperative effort between the US side and the Kola NPP, the milestones indicated in this project work pian are dependent upon NPP activities. If the application of seaiant materiais to all the penerrations, doors, harches, seams, and surfaces of the confinement is not completed during the upcoming piant outage in May 1996 by the Kola NPP staff, then the project will be delayed until after the subsequent plant outage. 


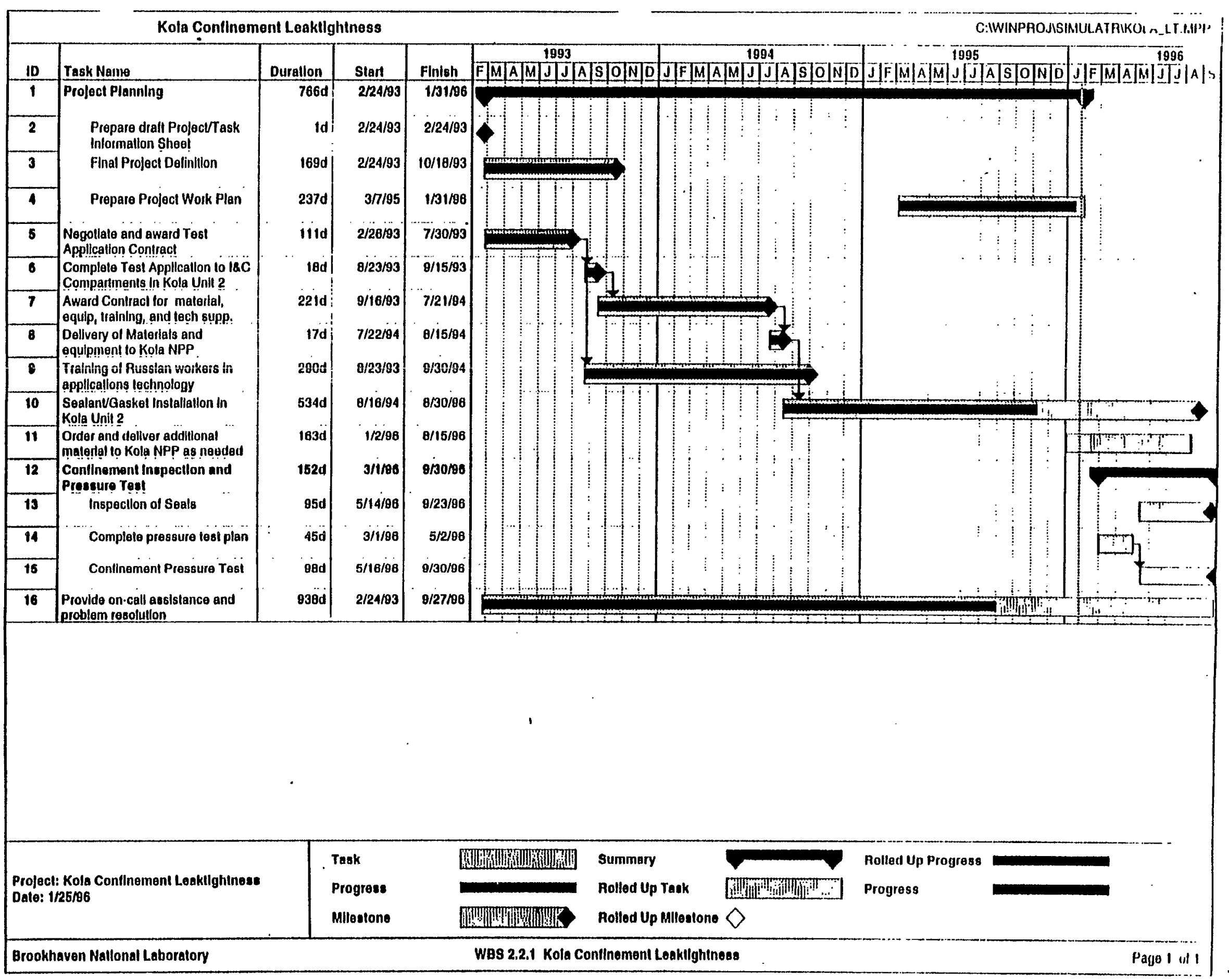




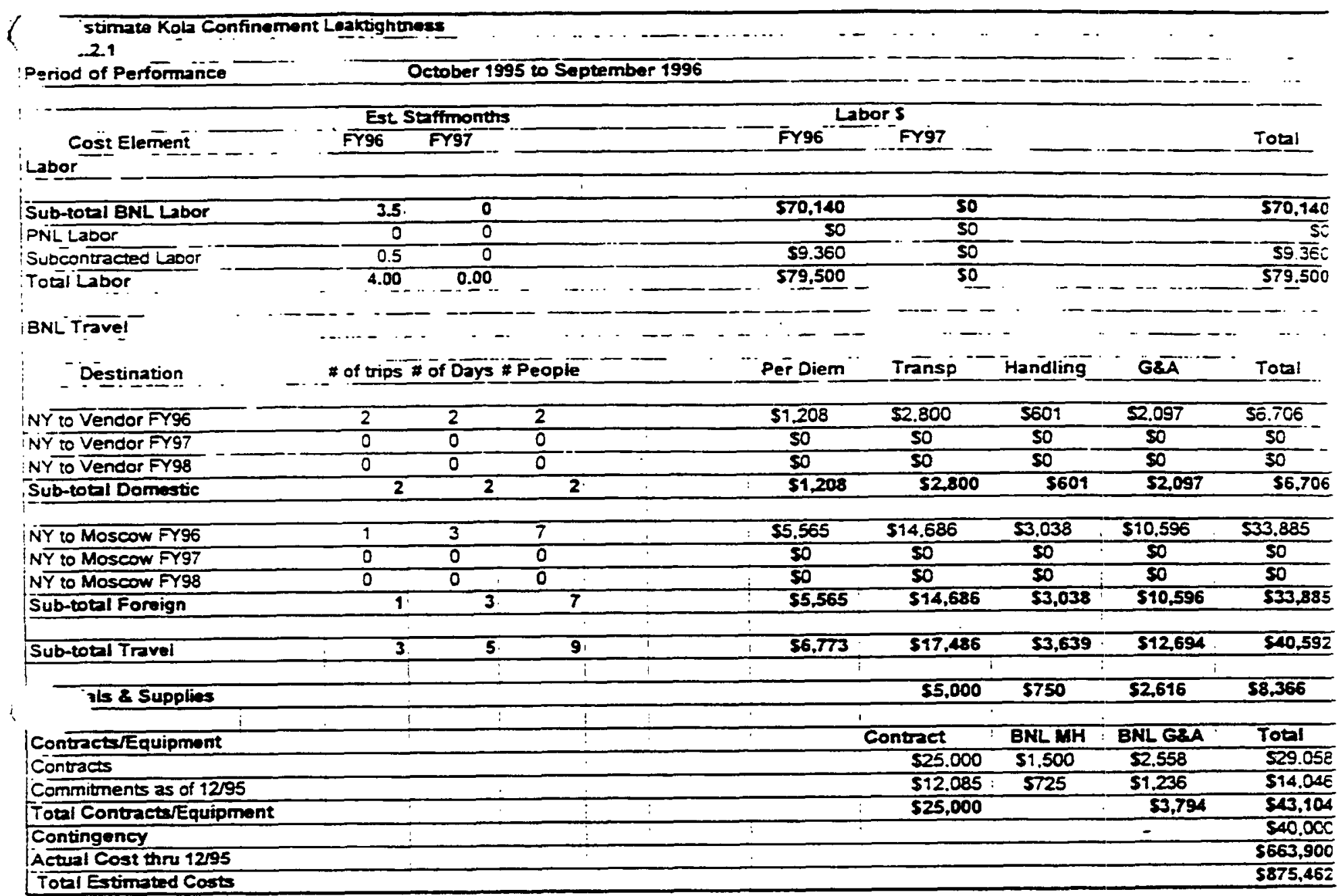


Cost Eallmate Kola Conlinement Leakllghtness

WBS 2.2.1

Perlod of Parformance

\begin{tabular}{|c|c|c|c|c|c|c|c|c|c|c|c|c|c|c|c|}
\hline & Dett.93 & Mov-9s & Dec.95 & $\operatorname{Jan} \cdot 96$ & Fab.98 & Mar-96 & Apr-90 & May.98 & Jun.96 & Jul.96 & Aug.96 & Sep.96 & FY94/FY95 & FY96 & Iuld \\
\hline Stutfmonthe & & & & 0.44 & 0.14 & 0.14 & 0.14 & 0.14 & 011 & 0.41 & 044 & 044 & & 4 & \\
\hline Labors & & & & 90,033 & 30,633 & $\$ 0,033$ & 98,033 & 50,033 & 38,833 & $\$ 6,033$ & $\$ 8.033$ & $\$ 6.833$ & & $\$ 79,500$ & $3 \sqrt{3} \leq 11$. \\
\hline Traval & & & & & & $\$ 3,353$ & & $\$ 33,805$ & & 33,354 & & & & $\$ 40.592$ & s+u:s. \\
\hline Materials \& Suppllor & & & & & & $\$ 0,366$ & & & & & & & & $\$ 8,366$ & If Jue \\
\hline Contracts & & & & & & & $\$ 14,040$ & & & $\$ 29,056$ & & & & $\$ 13,104$ & 543164 \\
\hline Contingency & - & & & & & & & & & & & $\$ 40,000$ & & $\$ 10.000$ & S(1) (114)( \\
\hline Actual Cout to Date & $\$ 772$ & 90 & $\$ 0$ & & & & & & & & & & 9663,128 & $\$ 772$ & Soos \\
\hline Tolal Eatlmalod Cools & 3772 & 90 & 10 & $\$ 8,033$ & 88,033 & $\$ 20,682$ & $\$ 22,079$ & $\$ 42,718$ & $\$ 8,833$ & $\$ 41,245$ & 50,033 & $\$ 48,033$ & $\$ 663,128$ & $\$ 212,334$ & 5873.402 \\
\hline $\begin{array}{l}\text { Funding FYoz'ss } \\
\text { Funding needed FY94 } \\
\text { Total Fundlng }\end{array}$ & & & & $\begin{array}{l}\$ 683,835 \\
\$ 181,527 \\
\$ 876,462\end{array}$ & & & & & & & & & & & \\
\hline
\end{tabular}




\section{ATTACHMENT 2}

Foreign Travel Trip Report of G.A. Greene 5/24-30, 1996 to Kola Nuclear Power Plant Polyarnie Zori, Russia 
DOE Trip No. 9603507

SUMMARY

FOREIGN TRAVEL TRIP REPORT

G. Alanson Greene, Mechanical Engineer
516-344-2296
Department of Advanced Technology
Building 820M
BROOKHAVEN NATIONAL LABORATORY

June 7, 1996

Dates of Trip:

May 24-30, 1996

Destination: $\quad$ Kola Nuclear Power Plant, Polyarnie Zori, Russia

\title{
Statement of Purpose of Trip:
}

The purpose of the trip is to lend technical support and consulting to the staff at the Kola NPP in their integrated reactor safety program. During the trip, a walkdown of the Kola Unit 2 confinement will be conducted in order to visually examine the condition of the confinement boundary and sealant. The confinement pressurization and leaktightness testing will be witnessed. The status of the installation of the high-level confinement radiation monitors will be reviewed and all action items decided. Future activities will be discussed.

\begin{abstract}
:
The walkdown of Unit 2 of the Kola NPP was conducted in concert with the under pressurization leak tightness tests of the confinement. Leakage points were identified and the defects were corrected by the application of sealant material where possible. The hutch locks, isolation valves, new gaskets, and the sealant have been installed during the current outage. The over pressurization test was observed following the under pressurization test. Discussions were held with the Kola management concerning their need for additional aid in the form of similar hardware for the upgrade of Unit 1 , which goes into an outage on July 1, 1996. A review of the installation of the confinement radiation detectors was held and the project status was discussed. A conference call was scheduled for June 6, 1996 between Kola, BNL, and Victoreen to begin planning for a return visit to Kola for the final installation of the high level confinement radiation monitoring system.
\end{abstract}




\section{Detaiied Trip Report}

George Greene (BNL) visited the Kola NPP (Unit 2) in Polyarnie Zori, Russia, from May 24-May 30, 1996, to review the current status of the installation of the high-level confinement radiation monitor system, and to witness and participate in the Unit 2 confinement leaktightness tests that were planned for May 28-30.

The four radiation monitors have been installed in the Kola Unit 2 confinement on the steam generator level in the vicinity of two steam generators and two primary coolant loops. The four sets of in-confinement power and signal cables have been pulled through steel conduits and have been passed through the confinement penetrations into the reactor building (exconfinement). At the request of the Kola management, an additional 1000 feet of RG59 coaxial cable has been added to the shipment of the two field calibrators; this cable is needed to complete the wiring to the readout devices and the remote displays. Matrix International is making progress on shipping this material by air to Moscow and then by truck to Kola.

The confinement lealtightness testing began on May 26 and continued until May 28. The details of the test procedures are contained in a Kola test protocol document, a copy of which was supplied. The results of the testing were faxed to BNL in a summary report. Both documents are on file at BNL. A short summary of the tests follows. The first part of the leaktightness testing involved an under pressurization test in which a vacuum was pulled on the confinement of 226 $\mathrm{mm} \mathrm{H}_{2} \mathrm{O}$ by operation of the confinement ventilation fans, resulting in an in-flow of air through defects in the confinement boundary. During the under pressure test, personnel entered the confinement and examined the boundaries for leaks. These were marked and later repaired with sealant material, after the ventilation system had been sealed off to measure the time for the confinement to retum to ambient pressure. Next, the overpressurization test was performed. A positive pressure was established in the confinement by operation of a compressor, and the resulting pressure in the confinement was measured. Leakage sites were again located and, at the end of the pressurization test, the leakage rate was determined (after the compressor had been shut down) by. measuring the time for the confinement to bleed down to the ambient pressure (ie., $\left.P_{\text {and }}=0\right)$.

The Kola summary report indicates that during the 1994 outage the Unit 2 confinement had been able to be pressurized to $70 \mathrm{~mm} \mathrm{H}_{2} \mathrm{O}$ and exhibited a leak rate of 4950 vol\%/day. However, during the 1996 tests, the confinement was able to be pressurized to $275 \mathrm{~mm} \mathrm{H}_{2} \mathrm{O}$ and the leakage was reduced to $768 \mathrm{vol} \% /$ day. The sharp reduction in the measured leak rate can be attributed to the confinement leakage upgrades supplied through the INSP program: new isolation valves, replacement hutch locks, new gaskets, and application of sealant material to local defect sites. Several dozen leak sites remain which the plant intends to repair prior to startup on June 7 , 1996. The reported leak rate was measured with these known defects yet unrepaired, hence the leakage at startup should be less than reported above. The Kola staff indicated that they were prepared to continue to upgrade the Unit 2 confinement to further reduce the leakage, and that they were interested in applying the same upgrades to Unit 1, another VVER 440-230 of similar age. 


\section{Appendix}

Itinerary:

May 24, 1996

May 25

May 26

May 26-28

May 29

May 30
Depart New York JFK

Official Stop Over in St. Petersburg

Arrive Polyarnie Zori, Russia

Observe Leaktightness Tests and Discuss

Status of Radiation Monitor Project

Depart Polyarnie Zori, Russia; Official Stop

Over in Helsinki

Arrive New York JFK

\section{People Contacted:}

Gennady Paradnikov Sergey Gorelikhin Leonid Popruzhko Anatoly Tutunnik

\begin{abstract}
Head of Adjustment and Startup Department Deputy Head of Adjustment and Startup Department Engineer-in-Charge of Radiation Monitor Installation Deputy Chief Engineer
\end{abstract}

\section{Literature Acquired:}

Procedural Guide for Conducting Leaktightness Testing of the Kola Confinement, on file in Russian.

Summary Report of 1996 Leaktightness Tests of Kola NPP Unit 2, translated to English and attached (9 pages). 


\section{ATTACHMENT 3}

Foreign Travel Trip Report of G.A. Greene 10/11-19, 1996 to Kola Nuclear Power Plant Polyarnie Zori, Russia 


\section{BROOKHAVEN NATIONAL LABORATORY}

\section{MEMORANDUM}

DATE: . October 24, 1996

TO: $\quad$ Vanessa E. Crump

FROM:

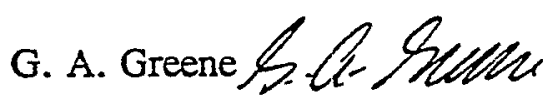

SUBJECT: Foreign Travel Trip Report and Travel Voucher for Trip \#9606937

I have attached my foreign travel trip report with copies of three attachments. The attachments are designated by number with post-its. Please remove the post-its and type "ATTACHMENT NO. __ at the top of each one.

I have also attached the necessary information for the travel voucher, including the airline receipt, two limousine receipts, copies of two checks to Travisa, cash advance, travel itinerary, my itemized expenses, and a sample "lodging and meals expense report" to assist you in preparing the travel voucher. I estimate a refund of approximately $\$ 311.00$ due to me. Please try to have the voucher ready for my signature by October 29; if that will not be possible, let me know right away.

Cc: J. G. Guppy

A. W. Reisman

\footnotetext{
To V. Grump

1130

$10 / 24 / 96$
} 
DOE Trip No. 9606937

\title{
SUMMARY
}

\section{FOREIGN TRA VEL TRIP REPORT}

\author{
George Alanson Greene, Mechanical Engineer \\ 516-344-2296 \\ Department of Advanced Technology \\ Building 820M \\ BROOKHAVEN NATIONAL LABORATORY
}

October 24, 1996

Dates of Trip:

October 11-19, 1996

Destination: $\quad$ Kola Nuclear Power Plant, Polyarnie Zori, Russia

\section{Statement of Purpose of Trip:}

The purpose of the trip is to complete the installation of the confinement high-level radiation monitoring system and to bring the system on line. In addition, the status of other INSP projects at the Kola NPP are to be reviewed, including the confinement leaktightness upgrades, the confinement isolation valves, and the emergency backup batteries. Other discussion points include the translation diskettes of the manual for the radiation monitoring system, the compilation of US standards for confinement radiation monitoring, and the contract with Kola for installation of the radiation monitoring system.

\begin{abstract}
:
Two of the four radiation monitors were installed in the confinement and all electrical connections to the readout devices in the Unit 2 control room and to the remote indicators were completed. Only one detector system is operational; there is a short in the wiring for the second detector which we believe is a result of damage to the detector connector during hookup by the Kola staff. The other two detectors were not mounted in the confinement during our visit as a result of a misunderstanding. Kola staff will mount them and complete the wiring as we demonstrated for the other two detectors. A return visit will be required during the next outage to complete the installation of the radiation monitoring system. An update was given on the leaktightness work for Units 1 and 2. The status of the installation of the emergency backup batteries and the schedule for completion of the installation were discussed. A request for manual controls for two of the isolation valves was received for consideration. The translation diskettes of the manual for the radiation monitoring system were delivered, the US standards for confinement radiation monitoring were sent, and the $\$ 14,000.00$ contract for installation of the cables for the radiation monitoring system was discussed.
\end{abstract}




\section{Detailed Trip Report}

Confinement Radiation Monitoring System for Kola Unit 2. BNL and Victoreen representatives visited the Kola NPP (October 11-19, 1996) to begin the final installation of the high-level confinement radiation monitoring system in Kola Unit 2. Non-standard connections were constructed at the confinement penetrations for the power and signal cables for each of the four detectors. The power and signal cables were terminated in a temporary rack in the reactor control röom along with the wires from the four remote alarming-indicators. Only two of the four detectors were installed in the confinement, therefore we were only able to work on two detectors. One train of two detectors was wired to the readouts, a recorder, and two remote indicators; Kola staff will wire the second train themselves in exactly the same configuration as the first train. When the system was calibrated, all four readouts, two recorders, and four remote indicators worked properly. However, one cable was accidentally shorted out at the detector by the Kola staff during installation, so only one of the four detector channels was able to be made operational. This channel was tested with the radioactive field calibrator and it operated exactly as it had been calibrated at the Victoreen Company. It will be necessary to return to Kola during the next scheduled outage to correct the cabling deficiencies and to bring the entire system operational. It may be desirable to bring one Kola staff to Victoreen for in-depth training on the system before then.

Status of Confinement Leaktightness, Isolation Valves, and Emergency Backup Batteries ai Kola NPP. The status of the INSP projects indicated above were determined through briefings by the cognizant Kola personnel during the visit to install the confinement high-level radiation monitoring system. Discussions were held with $T$. Petkevich (Chief of Localizing Systems Laboratory) concerning the leaktightness upgrades and the confinement isolation valves. At the time of my visit in May 1996, 21 leak sites were identified for correction prior to restart of Unit 2 in June 1996. Kola personnel were able to correct 15 of the 21 defects prior to restart (see Attachment 1). A total of fifteen additional defects have been identified for correction during the next scheduled outage. As for Unit 1 which is presently on an outage, $80 \%$ of the planned work on leaktightness has been completed. Kola has requested additional gasket material, sealant material, and valves in a memo from the plant chief engineer, which will be translated and forwarded for consideration (Attachment 2 in Russian). Prior to restart of Unit 1, leaktightness tests will be performed as was done for Unit 2 in May 1996. T. Petkevich requested that I look into her request for manual controls for two of the isolation valves which had been sent to Burns and Roe in May 1996. This request was communicated to R. Denning by telephone and is included in this report as Attachment 3. Discussions were held with A. Simeonov (Deputy Chief of the Electrical Department) concerning the status of the installation of the emergency backup batteries for Units 1 and 2. Two batteries and their switching panels were installed for Unit 2 in June 1996. The two batteries and switching panels for Unit 1 are currently being installed and are expected to be completed by the end of October 1996. The fifth battery and switching panel system which is common to both units is being installed and is expected to be completed before restart of Unit 1. 


\section{Appendix}

Itinerary:

October 11, 1996

October 12

October 13-17

October 18

October 19
Depart New York JFK Arrive Polyarnie Zori, Russia Install Radiation Monitor System and Discuss Status of INSP Projects at Kola Depart Polyarnie Zori, Russia; Official Stop Over in Oslo Arrive New York JFK

\section{People Contacted:}

Gennady Paradnikov Sergey Gorelikhin Leonid Popruzhko Tatiana Petkevich Alexander Simeonov Marina Kasakova
Head of Setup, Testing, and Startup Department Deputy Head of Adjustment and Startup Department Engineer-in-Charge of Radiation Monitor Installation Chief of Localizing Systems Laboratory Deputy Chief of the Electrical Department Kola Interpreter

\section{Literature Acquired:}

1. Update to the "Summary Report of 1996 Leaktightness Tests of Kola NPP Unit 2," translated to English ( 9 pages).

2. Memo from Omelchuk to Greene, "Request For Additional Gasket Material, Sealant Material, and Valves," dated October 16, 1996, in Russian (2 pages).

3. Memo from Omelchuk to Chuebon (Bums and Roe), "Request For Manual Controls For Two Isolation Valves," dated May 11, 1996, in Russian (2 pages). 


\section{ATTACHMENT 4}

Kola Nuclear Power Plant Procedural Guide for Confinement Leaktightness Testing 


\section{LEAKAGE TESTS OF THE PRESSURIZED \\ CONTAINMENT BUILDING SYSTEM}

UNITS 1 AND 2

WORKING PROGRAM

\section{APPROVED:}

Deputy chief engineer for operations

[signed]

Head of PTO

[signed]

Head of RTs

[signed]

Head of TsTsR

[signed]

Head of TsTAI

[signed]

Head of OI

[signed]

Head of OOT I TB

[signed]

Lead engineer of GENZiS

[signed]
Yu. N. Kostromin

S. A. Smirnov

S. I. Vasil'yev

A. B. Kabakov

V. A. Moskalenko

S. I. Videnin

Yu. Yu. Odinokov

V. M. Golubev
DEVELOPED BY:

Setup, testing and startup shop

Head of TsNIP

[signed]

G. S. Paradnikov 


\title{
RUSSIAN FEDERATION MINISTRY OF ATOMIC ENERGY \\ KOLA NUCLEAR POWER PLANT
}

\author{
APPROVED: \\ Head of 2 GU, GAN RF \\ [signed] \\ S. A. Adamchik \\ 8 September 1994 \\ CONFIRMED: \\ Deputy general director, NPP \\ operations directorate of the Gosenergoatom \\ concern \\ [signed] \\ S. P. Krylov \\ [seal] \\ 8 September 1994 \\ LEAKAGE TESTS OF THE PRESSURIZED \\ CONTAINMENT BUILDING SYSTEM. UNITS 1 AND 2. \\ WORKNNG PROGRAM
}

Kola NPP

APPROVED:

Chief engineer, [illegible]

TG N88/1463

K. L. Suknev

1 September, 1994

Deputy director, IYaR RNTs

Kurchatov Institute

TG/1006-1008

G. L. Lunin

6 June 1994

Chief designer of the OKB

Gidropress

[signed]

Deputy director, VNIIAES

[signed]

Yu. N. Filimontsev

1994

Chief engineer, Kola NPP

[signed]

V. V. Omel'chuk

1 May 1994 


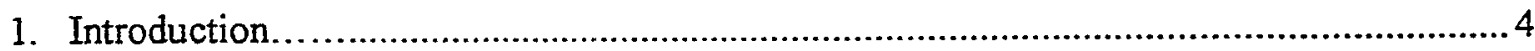

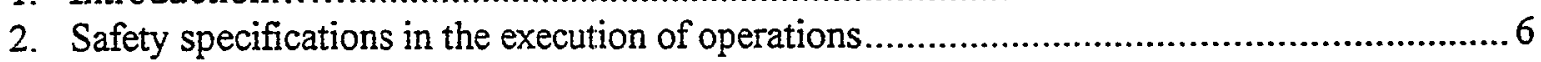

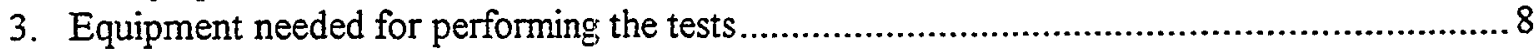

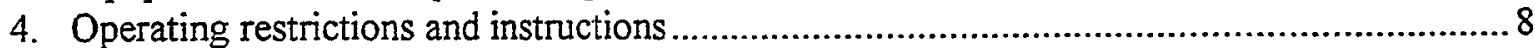

5. Readiness and initial state of the system, and related systems ................................... 10

6. List of variable parameters.............................................................................. 12

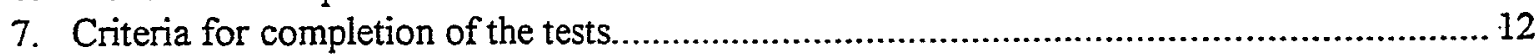

8. Sequence of actions in the performance of the tests .............................................. 13

9. Procedure for processing the test results ........................................................... 16

10. The form for the presentation of data and test results ............................................... 16

Annexes:

Annex 1. Diagram of pressurization system of containment

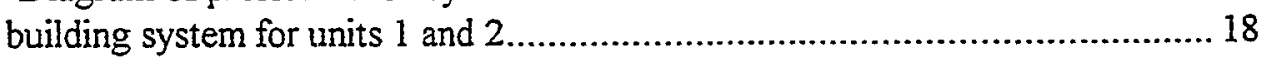

Annex 2. List of valves closed in tests of the containment building system ............................................................ 19

Annex 3. Procedure for processing test results ........................................................ 21

Annex 4. List of standard openings which isolate the containment building system ........................................................... 22

Annex 5. Patrol routes of the premises in vacuum leakage tests.

Annex 6. Patrol routes for containment building in integrated tests

Sheet for recording revisions and additions

Sheet for recording review

Sheet for familiarization with program (with revision and addition)

[footer - signatures of Petkevich, Gorelikhin, Paradnikov, Petroc and Omel'chuk] 12-11-20 PG-94

Pressurization leakage tests of containment building of accident containment system. Units 1 and 2. Working program.

Kola NPP Setup, Testing and Startup Department 


\section{INTRODUCTION}

1.1. This program defines the scope, sequence and procedures for conducting the leak testing of the pressurized containment building (GO) system of reactor units 1 and 2 , the criteria for the successful completion of the tests, and the required safety measures.

1.2. The tests of the GO system are divided into the following:

1.2.1. Preliminary integrity testing by vacuum tests to detect defects of the GO system. (PPR).

These tests are to be performed periodically, during the time for preventive maintenance

1.2.2. Integrated leakage tests to confirm the functional acceptability of the $\mathrm{GO}$ system as a safety containment system and to determine the levels of leakage from the GO system.

These tests are to be performed periodically during preventive maintenance on the power generating unit in question, once a year.

Integrated tests are to be performed with a positive pressure of $0.14 \mathrm{kgf} / \mathrm{cm}^{2}$ before the execution of operations for the prevention of rupture of the lining of the central room, the spent fuel pool, etc.

After the executions of the operations to ensure the integrity of the lining of the rooms indicated above, tests of the pressurized containment building system (SGO) are to be performed at a positive pressure of $0.3 \mathrm{kgf} \mathrm{cm}^{2}$.

1.3. The deadlines for the performance of the tests are defined by the "Working program for the startup of unit 1 (2) after preventive maintenance."

1.4. A representative of the setup, testing and startup department, to be designated at the first test according to the program by instruction from the chief engineer of the Kola Nuclear Power Plant, conducts technical supervision of the testing; thereafter the technical supervisor is to be designated by instruction of the head of the setup, startup and testing department (TsNIP).

1.5. Operating personnel of the reactor shop, the thermal automation and measurement department and the electrical shop, personnel of the centralized repair shop and personnel of the TsNIP are recruited for the tests at the discretion of the technical supervisor.

On-duty repair teams of the reactor shop (RTs), the centralized repair shop (TsTsR), the thermal automation and measurement department (TsTAI) and the electrical shop (ETs) are provided for the time required for the performance of the tests for the current elimination of defects.

The individuals responsible for the operations are the heads of the shops.

1.6. The technical supervisor of the tests is to execute all operations involved in the performance of work under this program after receiving the approval of the shift chief of the NPP or the phase shift chief (NSO). All switches are to be thrown by the shift personnel of the shops according to their areas of responsibility.

1.7. The NSO is to provide working supervision of the operations in strict adherence to 
the specifications of this program.

1.8. This program has been developed on the basis of the following documentation:

- "The VVER nuclear power plant, the V-230 and V-270 reactor plant, and the pressurized containment building system. Standard program of operating leakage tests. 230.270.KhA.KAV.PM";

- "Regulations for the construction and operation of safety containment systems for nuclear power plants. PN AEG-10-021-90";

- "Instructions for safety inspections in the operation of nuclear power facilities. RD-7-5."

BV -

1.9. List of abbreviations used in the text.

BShchU - unit control room;

GO - $\quad$ pressurized containment building;

$\mathrm{KZV}$ - exhaust stopper valve;

KZP - inlet stopper valve;

KID - $\quad$ excess pressure valve;

NSO - phase shift chief;

NS AES - nuclear power plant shift chief;

OOTITB - labor protection and safety equipment department;

OYaBiN - nuclear safety and reliability department;

PPR -

$P G$ preventive maintenance;

RTs - reactor shop;

TsD - radioactive decontamination department;

TSTAI - thermal automation and measurement department;

TsNIP - $\quad$ setup, testing and startup department;

TsTsR - centralized repair shop;

ShchAO - hardware section control board;

ETs - electrical shop;

SGO - pressurized containment building system.

1.11. The time required for the execution of this program is as follows:

the vacuum testing stage - 12 hours;

the integrated test stage -24 hours.

1.12. The tests in question are to be conducted on the basis of item 8.3 of the "Regulations for the construction and operation of safety containment systems for nuclear power plants. PN AEG-10-021-90." 


\section{SAFETY SPECIFICATIONS IN THE EXECUTION OF OPERATIONS}

2.1. In the performance of the tests, the following specifications apply: items 2.5 and 2.8 of the "Regulations for safety procedures in the operation of thermomechanical equipment of power stations and heating systems," chapters I and II of "Standard regulations for fire safety for industrial enterprises" and "Instructions on radiation safety of the NPP" (item 6, 7, 8 and 9) and chapters 4, 8 and 9 of the "Regulations for fire safety operation of power plants" (PPB-AS-93).

2.2 Personnel certified according to the official instructions are to be cleared to participate in the operations involved in the leakage testing of the pressurized enclosure system, provided they have successfully completed:

- a test on their knowledge of the regulations for safety procedures and fire safety regulations, and the working programs and testing methods;

- training on safety procedures, radiation safety and fire safety regulations.

2.3. During the performance of the tests, the operating personnel are to conduct continuous monitoring of the state of the reactor plant and the safety systems and are to report in advance to the technical supervisor of the tests concerning any changes in switches on the operating systems involved with the reactor plant.

2.4. For the period of the performance of leakage tests of the pressurized enclosure with positive pressure, all operations at the reactor unit not involved with the performance of the tests are to be suspended, and all personnel not participating in the performance of the tests (with the exception of operating personnel) are to be removed from the pressurized enclosure area. The beginning of testing is to be announced by loudspeaker. A safety zone is to be designated by warning posters: "Danger Zone, Access Prohibited." The beginning of the sealing of doors to the pressurized enclosure is to be considered the beginning of testing.

2.5. All types of operations in the pressurized enclosure and within the safety zone are to be suspended for the testing period. The presence of personnel not participating in the tests being conducted in the pressurized enclosure or within the established safety zone is not permitted. All areas directly adjoining the pressurized enclosure are considered to be associated with the safety zone.

2.6. The personnel participating in the tests are to be admitted to the pressurized enclosure according to a list approved by the test supervisor. The entry of personnel into the pressurized enclosure and their departure from it are to be monitored by the list.

2.7. The presence and proper working order of primary fire extinguishing equipment are to be verified before the beginning of testing.

2.8. Should a fire break out in the testing zone, the phase shift chief is to announce to following actions: 
- the immediate suspension of testing;

- the disengagement of the equipment which has been active in the tests;

- the dumping of positive pressure (or the vacuum in vacuum testing of the pressurized enclosure system;

- the unsealing of the pressurized enclosure to provide access to personnel for extinguishing the fire.

2.9. In the event of a fire in the unit control room (BShchU), the actions of item 2.8 are to be executed.

2.10. Scaffolding and support structures are to be installed by instruction of the technical supervisor of the tests for the inspection of the pressurized enclosure in locations where there are no stationary service platforms; these structures are to be dismantled and removed from the pressurized enclosure upon the conclusion of the tests.

2.11. The personnel participating in the performance of the tests are to be provided with individual protective equipment (helmets, coveralls and respirators). The personnel of the groups assigned to detect flaws in the components of the pressurized enclosure system are to have individual flashlights with a voltage not higher than $12 \mathrm{~V}$.

2.12. In the inspection of the inner surface of the pressurized enclosure in vacuum testing, deviation from the predefined routes and the use of equipment or devices not specified in advance for this purpose for access to the inspection points are prohibited. During the leakage tests of the pressurized enclosure using positive pressure, the inspection within the premises of the electrical shop and the thermal automation and measurement shop is to be performed in the presence of operating personnel of the shops in question. The inspection of the pressurized enclosure is to be performed not sooner than 10 minutes after the pressure steps specified in the working program have been achieved.

2.13. Any extraneous objects are to be cleared from the zone for the performance of the tests and the inner rooms of the pressurized enclosure.

2.14. The prevention of any possibility of the ignition of objects in the pressurized enclosure or the safety zone is to be ensured, and fuels and lubricants, oxygen cylinders and fuel gases are to be removed from the pressurized enclosure.

2.15. The command point of the technical supervisor of the tests is to be equipped with reliable operating communications (telephone or loudspeaker):

- with the compressor station control panel;

- with the control panel for the ventilation systems which provide the creation of a vacuum inside the pressurized enclosure;

- with the unit control room, the hardware section control board and rooms A103, A 105 and $\mathrm{A} 301$;

- with the personnel groups performing the search for defects;

- with the rooms of operating personnel of the reactor section. 
2.16. The following activities are not permitted during the tests:

- searching for defects in components of the pressurized enclosure by groups consisting of less than two people;

- opening or closing of the pressure doors or pressure hatches which seal the pressurized enclosure without a command from the technical supervisor for the tests;

- mechanical actions on the pressure lining (knocking on welds);

- the elimination of cracks or flaws under pressure by any method.

2.17. Access to the vacuum tests is provided according to thermal and radiation monitoring duties, while access to the pressurization tests is granted by order, with a notation in the operating log and the "Journal of records of operations by duties and orders." 


\section{EQUIPMENT NEEDED FOR PERFORMING THE TESTS}

3.1. Two pressure check gauges with a scale of $0-1 \mathrm{kgf} / \mathrm{cm}^{2}$ with an accuracy class of at least 0.4 are needed for performing the pressurization tests.

3.2. A U-shaped pressure and vacuum gauge with measurement limits of 200-500 $\mathrm{mmH}_{2} \mathrm{O}$ is needed for vacuum testing of the pressurized enclosure.

3.3. A computer of the MK type is needed for performing calculations to determine the amount of leakage.

3.4. The following are needed for detecting flaws:

- buckets - quantity 5 ;

- soap solution - 10 l;

- brushes - quantity 5;

- battery-powered flashlights - quantity 5.

3.5. Chalk ( 10 pieces) or oil paint (1 1 ) and 5-6 small brushes are needed for marking the locations of leaks. 


\section{OPERATING RESTRICTIONS AND INSTRUCTIONS}

4.1. Operations in regard to the opening of cut-off valves which are to be closed according to the list of annex 2 of this program are prohibited for the time required for performing the tests.

4.2. The performance of repair operations on valves, equipment or pipelines connected to the pressurized enclosure system or on sealed passages during the performance of the tests is prohibited.

4.3. Increasing the rate of change of the following parameters inside the pressurized enclosure system in the course of the performance of the tests is prohibited:

- the rate of increase of the pressure in the pressurized enclosure above $0.053 \mathrm{~kg} / \mathrm{cm} 2 \cdot \mathrm{h}$.

- the rate of decrease of the pressure in the pressurized enclosure above $1.03 \mathrm{kgf} / \mathrm{cm} 2 \cdot \mathrm{h}$.

- the rate of emergency pressure dumping from the pressurized enclosure (with the use of ventilation system $\mathrm{B}-4$ ) above $1.53 \mathrm{kgf} / \mathrm{cm} 2 \cdot \mathrm{h}$.

4.4. Pressure dumping from the pressurized enclosure system is to be performed by the engagement of ventilation systems B-2 (by switching on fan $1(2) B-2 / 1(2)$ and opening pressure valves $1(2) \mathrm{A} 2 / 1,2(3,4), 2 \mathrm{~A}-2 / 5,6,7,8$.

ventilation system V-4 may be engaged (switching on of fan 1(2) V-4-1(2) and opening of pressure valves $1(2) \mathrm{A}-4 / 1,2(3,4)$ ) for rapid pressure dumping in an emergency.

4.5. The compressor is to be switched on for the pressurization of the containment building system after determination of the radiation situation in the rooms of the pressurized containment building by order of the shift chief of the labor protection department or with his consent.

4.6. During the performance of the tests, the electrically actuated air flow isolating valves are closed by remote control; manual final sealing is not permitted.

4.7. During the performance of tests of the pressurized containment building (GO) under positive pressure of $0.14 \mathrm{kgf} / \mathrm{cm}^{2}$, the following actions are to be performed:

- after the pressure has been increased in the GO system, the pressure in the containment building is held at $0.13-0.14 \mathrm{kgf} / \mathrm{cm}^{2}$ for 2 hours (the stabilization time);

- an increase in the positive pressure in the GO above $0.14 \mathrm{kgf} / \mathrm{cm}^{2}$ is not permitted;

- in the performance of the first tests under this program, the leakage value is to be determined at three pressure stages of $0.05,0.1$ and $0.14 \mathrm{kgf} / \mathrm{cm}^{2}$; later it is determined only at the level of $0.14 \mathrm{kgf} / \mathrm{cm}^{2}$.

4.8. The following actions are to be executed in the performance of tests at a pressure of $0.3 \mathrm{kgf} / \mathrm{cm}^{2}$.

- an increase in the pressure in the containment building above $0.3 \mathrm{kgf} / \mathrm{cm}^{2}$ is not 
permitted;

- after the pressure in the $G O$ has been raised, the pressure in the $G O$ is held at $0.25-0.3$ $\mathrm{kgf} / \mathrm{cm}^{2}$ for 2 hours (the stabilization time);

- in the performance of the first tests of the pressurized containment building with a pressure of $0.3 \mathrm{kgf} / \mathrm{cm}^{2}$, the leakage value is determined at 2 pressure stages of 0.14 and 0.3 $\mathrm{kgf} / \mathrm{cm}^{2}$; later it is determined only at the level of $0.3 \mathrm{kgf} / \mathrm{cm}^{2}$.

4.9. During the rise in the pressure in the GO, the integrity of the lining of the spent fuel pool is monitored (according to the appearance of air bubbles in the water or by sound). In the event of the appearance of signs of a rupture, the tests are suspended, and the pressure is released from the containment building.

\section{READINESS AND INITIAL STATE OF THE SYSTEM, AND RELATED SYSTEMS}

5.1. The reactor plant is in a subcritical state, and the equipment of the primary loop is cooled to a temperature below $50^{\circ} \mathrm{C}$. The safety systems are on "hot" standby.

The temperature in the steam generator box is not above $33^{\circ} \mathrm{C}$.

5.2. All the cut-off valves which provide containment of the pressurized space are closed (according to Annex 2). A membrane is installed on the bubbler tank. The membranes on the reactor shaft cantilever have been dismantled.

The pressure relief valves (KID) from rooms A-004/1, 2 into the steam generator box in reactor unit 1 are wedged in the open position.

The traps in rooms A-004/3, 4 are open in unit 2.

5.3. All the containment hatches and doors of the $\mathrm{GO}$ are closed and sealed (with the exception of the doors in A-102/1 (2), 103/1 (2), 002/1 (2) at $+2.7, A-106 / 1$ (2), between A$102 / 1,2$ and A-204/1, 2, A010/1 (2), A-004/1, $2(3,4)$ ), and the protective cover of the reactor and the process flange are installed and sealed, while the top covers of hatches of the central hall and system R-1 are removed. The protective plate of the spent fuel pool is removed.

5.4. Tank B-8 is filled to the nominal level.

5.5. The special compressor (system IS10) is prepared for operation for effecting the pressurization of the containment building. Seals are installed on the pressure pipelines:

- of unit 3 in room A-104/1;

- of unit 4 in room A-104/2;

- of the ShLA air traps of units 3 and 4 in rooms A-213/1,2;

- of the phase unit 2 (1) which is not being tested in rooms A-107/2 (V-214/1).

Valves 4US10S33 on the pressure pipeline of unit 4 and 1,2US10S07, 08 on the pressure pipelines of units 1 and 2 of phase 1 are closed.

The stopper on the pressure pipeline of the first phase in the platform of phase II and on 
the pressure pipeline of the unit being tested in room V-214/1 (A-107/2) is dismantled.

5.6. The reliability of the readings of the monitoring and measurement instruments used in the tests is verified - the thermal automation and measurement department (TsTAI) is responsible.

5.7. The lighting inside the $\mathrm{GO}$ and around the entire outside perimeter of the $\mathrm{GO}$ is to be in full working order - the electrical shop is responsible.

5.8. The telephone and loudspeaker communications are to be operational.

5.9. The ventilation systems $R-1, P-4, V-2, V-4, R-2$ and $V-1$ are switched off.

5.10. The ventilation systems $1(2) \mathrm{V}-2$ and $1(2) \mathrm{V}-4$ are ready for operation for dumping the positive pressure from the containment building system. Circuit protection has been removed for switching off the fans and valves of the system 1(2) V-2 and IV-4 with an increase in the pressure in the steam generator box to $30 \mathrm{mmH}_{2} \mathrm{O}$ (from relay $203 \mathrm{RP}$ (203RP) for $1 \mathrm{~V}-2-1(\overline{2})$, from relay $3 R P(3 R P)$ for $2 \mathrm{~V}-2-1(2)$, and from relay $217 R P(217(R P)$ for $1 V-4-1(2)$; all the relays are situated on panel P4 of the hardware section control board). In the tests of the $G O$ with a pressure greater than $0.2 \mathrm{kgf} / \mathrm{cm}^{2}$, the circuit protection is removed for switching off the fans $2 \mathrm{~V}$ 4-1(2) (from relay 5R32a (5R32-2), panel 100 ShchPR-2, and relay 6R33a (6R34), panel 24 BShchU-2), and circuit protection is removed in regard to the closing of the pressure valves of system 2V-2: $2 \mathrm{~A}-2 / 8,6$ (from relay $5 \mathrm{RP} 32-1$, panel 100 ShchPR-2) and 2A-2/5, 7 (from relay 6R33, panel $24 \mathrm{BShchU}=2$ ), and system $2 \mathrm{~V}-4$ : 2A-4/6, 7 (from relay 5R32-1, panel 100 ShchPR2) and $2 A-4 / 5$ (from relay $6 R 33$, panel 24 BShchU-2), with an increase in the pressure in the steam generator box to $0.2 \mathrm{kgf} / \mathrm{cm}^{2}$.

\subsection{Butterfly-type valves $1(2) \mathrm{V}-4 / 1-6$ and $1(2) \mathrm{G}-4$ are opened.}

5.12. Before the beginning of the tests, the heads of the sections and subunits (reactor shop RTs, electrical shop ETs, thermal automation and measurement department TsTAI, centralized repair shop $T s T s R, O K M i D$, the radioactive decontamination department $T s D$, the labor protection and safety equipment department OOTiTB, the nuclear safety and reliability department OYaBiN and the setup, testing and startup department TsNIP) are to make an entry in the log of the nuclear power plant shift chief concerning the completion of operations at the unit and the readiness for the performance of tests of the containment building (a report by telephone to the NPP shif chief concerning the readiness for the performance of the tests is permitted as an exception).

5.13. The electrical control circuits of the NBS are to be switched off by PB keys on panel A7.

5.14. Insulating separators are to be installed on the normally closed contacts 3-4 and 5-6 or relays IRA3 and 1RA4 in PA3-1 and 2 of control board SUZ-1 (2) for avoiding the startup of the ASP. 
5.15. The following systems are to be sealed off according to the regular procedure: the main circulating pump safety valves, the control rods system safety valves and the service water of system R-1.

5.16. Just before the performance of tests of the containment building system with a positive pressure of $0.3 \mathrm{kgf} / \mathrm{cm}^{2}$, the following operations are to be executed:

- holes with a diameter of $5 \mathrm{~mm}$ are drilled in the stainless steel lining of the central hall at a spacing of $2000 \times 2000 \mathrm{~mm}$;

- - operations are performed in accordance with the plan SPbAEP on the unfastening of the corners of the spent fuel pool lining, the BZT inspection shaft, the upper block inspection shaft $(\mathrm{A} 005, \mathrm{~A} 221)$ and the room for storage of the control rod drive units (A-007);

- the spent fuel pool is filled to the top overflow level (mark +11.1).

\section{LIST OF VARIABLE PARAMETERS}

6.1. The pressure of the air medium of the pressurized containment building is to be recorded with two standard pressure gauges situated in rooms A-015/1 (2) and A-102/1 (2) instead of the regular EKM, or with pressure gauges located at the instrument station for the tests of the containment building, room V-109/1.

6.2. The vacuum in the rooms of the pressurized containment building are recorded with a U-shaped pressure and vacuum gauge situated in room A-103/1 (2) instead of the regular EKM. 6-12-68).

6.3. The atmospheric pressure is checked every hour with the weather station (telephone 


\section{CRITERIA FOR COMPLETION OF THE TESTS}

7.1. The criterion in the first tests of the pressurized containment building (GO) under this program is the determination of the value of the leakage from the $\mathrm{GO}$ at three positive pressure steps: $0.05 \mathrm{kgf} / \mathrm{cm}^{2}, 0.1 \mathrm{kgf} / \mathrm{cm}^{2}$ and $0.14 \mathrm{kgf} / \mathrm{cm}^{2}$.

7.2. The criterion for the subsequent tests is to achieve the equality $L_{e k}=L_{k} \cdot 1.15$, where

$\mathrm{L}_{\mathrm{ek}}$ - is the leakage value at a positive pressure in the $\mathrm{GO}$ of $0.14 \mathrm{kgf} / \mathrm{cm}^{2}$, obtained during the tests;

$L_{k}-\quad$ is the certificate leakage value at a positive pressure $P_{\text {pos }}=0.14 \mathrm{kgf} / \mathrm{cm}^{2}$, which satisfies the requirements of the NTD with respect to the radiation situation at the boundary of the buffer zone (SZZ).

7.3. In the pressurization tests, it is necessary to adhere to the criterion of reliability of the tests, $\Delta \mathrm{L}_{\mathrm{si}} / \mathrm{L}_{\mathrm{ek}} \leq 0.5$, with a confidence $\mathrm{P}_{\mathrm{d}} \geq 0.95$.

7.4. The criterion for the completion of vacuum testing of the $\mathrm{GO}$ is the composition of a comprehensive list of defects of the components of the containment building from the inside of the building.

7.5. The criterion for tests of the $G O$ with a positive pressure of $0.3 \mathrm{kgf} / \mathrm{cm}^{2}$ is defined as follows:

- to determine $L_{\mathrm{ck}}$ at a pressure in the $\mathrm{GO}$ of $0.14 \mathrm{kgf} / \mathrm{cm}^{2}$;

- if the condition of item 7.2 has been fulfilled, to raise the pressure in the GO to $0.3 \mathrm{kgf} / \mathrm{cm}^{2}$ and determine $\mathrm{L}_{\mathrm{ek}}{ }^{0.3}$.

This value of $L_{c k}^{0.3}$ will be the criterion for all subsequent tests. In this context, the following equality is to be fulfilled in the subsequent tests:

$$
\mathrm{L}_{\mathrm{ek}}=\mathrm{L}_{\mathrm{ek}}^{0.3} \cdot 1.15 \text {, where }
$$

$L_{e \mathrm{k}}=$ is the leakage value at a positive pressure in the $G O$ of $0.3 \mathrm{kgf} / \mathrm{cm}^{2}$, obtained during the tests. 


\section{SEQUENCE OF ACTIONS IN THE PERFORMANCE OF THE TESTS}

8.1. The vacuum tests of the pressurized containment building system.

8.1.1. The pressure relief valves in system P-4 situated between rooms A-202/1 and A$102 / 1$ are to be wedged in the closed position.

8.1.2. All personnel not involved in conducting the tests are to be removed from the premises of the GO.

8.1.3. The personnel participating in the tests are to be admitted inside the pressurized containment building system through the sluice at +2.7 and through the doors to rooms A-106/1 (2), A-010/1 (2) and A-004/1, $2(3,4)$, after which the doors of rooms A-103/1 (2), A-106/1 (2) and $\mathrm{A}-010 / 1(2)$ and $\mathrm{A}-004 / 1,2(3,4)$ are to be closed.

8.1.4. The two fans of system V-4 1 (2) V-4-4-1, 2 are to be switched on, and the opening of pressure valves 1 (2) A-4/1, 2, 3, 4 and the butterfly-type valve lB-4 is to be monitored, and pressure valves $2 \mathrm{~A}-4 / 5,6,7$ are to be opened.

8.1.5. When an established vacuum has been achieved in the $\mathrm{GO}$, the initiation of the inspection of the structural components of the $\mathrm{GO}$ is to be announced by loudspeaker.

When the vacuum level is insufficient (less than $100 \mathrm{mmH}_{2} \mathrm{O}$ ), the ventilation system $\mathrm{V}-2$ is to be switched on, for which the following air cut-off valves are opened:

unit $1-\mathrm{K}-11 / 1-4,6-9,11,14-16,18$;

unit $2-\mathrm{K}-11 / 21-25,27-29,32-35$; the fans 1 (2) V-2-1, 2 are switched on, the opening of pressure valves 1 (2)A-2/1, 2, 3, 4 is monitored, and valves $2 \mathrm{~A}-2 / 5,6,7,8$ are opened.

The components of the GO are to be inspected by patrol routes (Annex 5).

8.1.6. Defects are to be detected by visual inspection or by the application of soap solution to the components of the containment building.

8.1.7. The defects discovered are to be marked with chalk or paint, and their locations are to be entered in the log.

8.1.8. Upon the completion of the inspection patrols, the fans of ventilation systems V-2 and V-4 are to be switched off, and the following steam cut-off valves of system V-2 are to be opened:

for unit $1-\mathrm{K}-12 / 1,3,4,8-11,14$;

for unit $2-\mathrm{K}-12 / 21,24,27,28,29$.

After balancing of the pressure in the GO with atmospheric pressure, the personnel are to be removed from the premises of the containment building system.

8.1.9. Upon the completion of the tests:

- the fluid pressure and vacuum gauges used for monitoring the vacuum in the GO are to be dismantled;

- the fixers are to be removed from the pressure relief valves of ventilation system P-4.

8.2. The integrated pressurization leakage tests of the containment building system with a positive pressure of $0.14 \mathrm{kgf} / \mathrm{cm}^{2}$.

8.2.1. The GO is to be sealed in accordance with section 5 of this program.

8.2.2. All personnel are to be removed from the premises of the GO, after which all the 
outside doors of the GO are to be closed. A monitor is placed on a stand of the central hall.

8.2.3. The valves for feeding compressed air from the compressor plant 1(2)US10S07 (room V-214/1 for unit 1 and A-107/2 for unit 2) and 1 (2)US 10 SOS are to be opened.

8.2.4. Authorization is obtained from the NPP shift chief before the initiation of the tests.

8.2.5. The compressor is switched on, and the raising of the pressure in the GO is initiated. The time of switching on of the compressor is to be recorded.

8.2.6. The pressure is to be increased in steps of $0.05,0.1$ and $0.14 \mathrm{kgf} / \mathrm{cm}^{2}$. The changes in the air pressure and the air temperature are to be recorded in a testing log.

8:2.7. The components of the pressurized containment building system which affect the integrity of the system and the structural elements are to be inspected at each step, with special attention devoted to the deformations of the components affecting the safety of the nuclear power plant. Monitors on a stand are to check the integnity of the lining of the spent fuel pool.

8.2.8. During the inspection, special attention is to be devoted to the condition of the outer doors, hatches and passages, the seais of the protective cover of the reactor and the containment valves, the structural elements at the points under the greatest stresses (in the areas of joints and contact welds between component elements and solid concrete) and crack openings and deformations.

8.2.9. The defects in the components of the GO system detected in the process of increasing of the pressure are to be eliminated; the defects which are not eliminated are to be entered in the testing log.

8.2.10. If defects which threaten the integrity of the pressurized containment building system are discovered in the process of increasing of the pressure, the compressor is to be switched off immediately, and the pressure in the containment building is to be released in accordance with item 4.4 of this program.

8.2.11. When the positive pressure $P_{\text {pos }}$ in the containment building reaches $0.14 \mathrm{kgf} / \mathrm{cm}^{2}$, the valves on the compressed air feed line 1(2)US10S07 are to be closed, and the compressor is to be switched off.

8.2.12. The pressure in the GO system is to be held for 2 hours within limits of $0.13-0.14$ $\mathrm{kgf} / \mathrm{cm}^{2}$ by switching the compressor on and off. At the end of this period, the pressure is to be increased to $0.14 \mathrm{kgf} / \mathrm{cm}^{2}$.

8.2.13. The technical examination of the pressurized containment building system is to be performed by a committee appointed by order of the director of the Kola Nuclear Power Plant.

8.2.14. The recording of the variations in pressure is to be initiated at the same time at all the measurement points. The recording is to be performed at least once every 2 minutes up to a pressure in the GO $P_{\text {pos }}=0.02 \mathrm{kgf} / \mathrm{cm}^{2}$.

8.2.15. A preliminary calculation of the amount of leakage is to be performed. In the event that the calculated leakage level does not satisfy the criterion of item 7.2 of this program, the pressure must be released from the GO system in accordance with item 4.4 of this program, the defects discovered must be eliminated, and the tests must be repeated.

8.2.16. With a positive pressure in the $G O$ system of $0.02 \mathrm{kgf} / \mathrm{cm}^{2}$, the tests are to be suspended, and the pressure is to be released from the containment building by switching on ventilation system $\mathrm{V}-2$.

8.2.17. Actions upon the completion of the tests:

- the standard pressure gauges are to be dismantled;

- a stopper is to be installed in the compressed air feed pipeline to the GO system in room 
$\mathrm{V}-214 / 1(\mathrm{~A}-107(2))$

- valve 1(2)US10S08 is to be closed;

- all the operating systems, ventilation systems and radiation monitoring systems are to be put into a condition which conforms to the "Operating regulations ...."

8.3. The integrated pressurization leakage tests of the containment building system with a positive pressure of $0.3 \mathrm{kgf} / \mathrm{cm}^{2}$.

8.3.1. Items 8.2.1 - 8.2.5 are to be fulfilled. Note: In the first tests of the containment building with a pressure of $0.3 \mathrm{kgf} / \mathrm{cm}^{2}$, items $8.2 .6-8.2 .12$ of this program are to be fulfilled.

The value of the leakage from the pressurized containment building is to be determined at pressure in the GO of $0.14 \mathrm{kgf} / \mathrm{cm}^{2}$.

If the leakage value obtained satisfies the criterion of item 7.2 , the tests are to continue.

8.3.2. The pressure is to be increased in steps of $0.1 \mathrm{kgf} / \mathrm{cm}^{2}$. The changes in the air pressure and the air temperature are to be recorded in the testing log.

8.3.3. The components of the pressurized containment building system which affect the integrity of the system and the structural elements are to be inspected at each step, with special attention devoted to the deformations of the components affecting the safety of the nuclear power plant. The monitors on a stand of the central hall is to check the integrity of the lining of the spent fuel pool.

8.3.4. During the inspection, special attention is to be devoted to the condition of the outer doors, hatches and passages, the seals of the protective cover of the reactor and the containment valves, the structural elements at the points under the greatest stresses (in the areas of joints and contact welds between component elements and solid concrete) and crack openings and deformations.

8.3.5. The defects in the components of the GO system detected in the process of increasing of the pressure are to be eliminated; the defects which are not eliminated are to be entered in the testing log.

8.3.6. If defects which threaten the integrity of the pressurized containment building system are discovered in the process of increasing of the pressure, the compressor is to be switched off immediately, and the pressure in the containment building is to be released in accordance with item 4.4 of this program.

8.3.7. When the positive pressure $\mathrm{P}_{\text {pos }}$ in the containment building system reaches $0.3 \mathrm{kgf} / \mathrm{cm}^{2}$, the valves on the compressed air feed line 1(2)US10S07 are to be closed, and the compressor is to be switched off.

8.3.8. The pressure in the GO system is to be held for 2 hours within limits of $0.25-0.3$ $\mathrm{kgf} / \mathrm{cm}^{2}$ by switching the compressor on and off. At the end of this period, the pressure is to be increased to $0.3 \mathrm{kgf} / \mathrm{cm}^{2}$.

8.3.9. The technical examination of the pressurized containment building system is to be performed by a committee appointed by order of the director of the Kola Nuclear Power Plant.

8.3.10. The recording of the variations in pressure is to be initiated at the same time at all the measurement points. The recording is to be performed at least once every 2 minutes up to a pressure in the $\mathrm{GO} \mathrm{P}_{\text {pos }}=0.05 \mathrm{kgf} / \mathrm{cm}^{2}$.

8.3.11. A preliminary calculation of the amount of leakage is to be performed. In the event that the calculated leakage level does not satisfy the criterion of item 7.5 of this program, the pressure must be released from the GO system in accordance with item 4.4 of this program, 
the defects discovered must be eliminated, and the tests must be repeated.

8.3.12. With a positive pressure in the $G O$ system of $0.05 \mathrm{kgf} / \mathrm{cm}^{2}$, the tests are to be suspended, and the pressure is to be released from the containment building by switching on ventilation system $\mathrm{V}-2$.

8.3.13. Actions upon the completion of the tests:

- the standard pressure gauges are to be dismantled;

- a stopper is to be installed in the compressed air feed pipeline to the GO system in room $\mathrm{V}-214 / 1(\mathrm{~A}-107(2))$;

- valve 1(2)US10S08 is to be closed;

- all the operating systems, ventilation systems and radiation monitoring systems are to be put into a condition which conforms to the "Operating regulations ...." 


\section{PROCEDURE FOR PROCESSING THE TEST RESULTS}

The level of leakage is to be calculated with the use of the results obtained and with the guidance of the requirements of Annex 3 in the form of integral leakage values at the stages of the testing positive pressure $P_{\text {pos }}$ of $0.05,0.1$ and $0.14 \mathrm{kgf} / \mathrm{cm}^{2}$.

The calculation of the leakage values at the pressure stages indicated above and the extrapolation of the test results to the design pressure may be performed by the calculation program Scont3.

The test result is to be extrapolated to a pressure $P_{\text {pos }}$ of $0.98 \mathrm{MPa}\left(4 \mathrm{kgf} / \mathrm{cm}^{2}\right)$. The calculation of the radiation situation at the boundary of the buffer zone (SZZ) is to be performed at the extrapolated leakage value. If the radiation situation at the boundary of the buffer zone at the extrapolated leakage value satisfies the requirements of the NTD, the leakage value obtained is to be recognized as satisfactory, and a conclusion to the effect that the pressurized containment building system is fit for operation is to be issued. The leakage value $L_{k}$ is to be entered in the certificate of the GO system.

Note:

1. Subsequent operating tests are to be performed with the station compressor plant for a pressure stage $P_{\text {pos }}=0.0294 \mathrm{MPa}\left(\left(0.14 \mathrm{kgf} / \mathrm{cm}^{2}\right)\right.$, and the calculation of the leakage level is to be performed accordingly for this pressure only.

2. After the performance of operations for the reinforcement of the lining of the spent fuel pool room, the central hall, etc., tests are to be performed only with a pressure of $0.3 \mathrm{kgf} / \mathrm{cm}^{2}$, and the leakage value is to be calculated for this pressure only. 


\section{THE FORM FOR THE PRESENTATION OF DATA AND TEST RESULTS}

10.1. A "Protocol of the results of leakage tests of the pressurized containment building system of unit 1 (2) in accordance with annex 5 of the 'Regulations for the construction and operation of containment safety systems of nuclear power plants'" PNAE G-10-21-90 is to be prepared from the test data.

10.2. In the light of the results of the technical examination, the committee is to prepare a report presenting a conclusion concerning the possibility of operation, indicating deadlines for the performance of subsequent technical examinations. 
Key:

1 - from special compressor;

2 - pipeline for pressurization of containment buildings of units 3 and 4;

3 - to traps of unit 4 ;

4 - to $\mathrm{GO}$ of unit 4

5 - containment building, unit 2;

6 - to traps of unit 3;

7 - to GO of unit 3;

8 - containment building, unit 1 ;

9 - Legend:

- flange joint;

- stopper;

- transition section;

- containment building pipeline passage. 
List of valves closed in tests of the containment building system

\begin{tabular}{|c|c|c|}
\hline 1 & 2 & 3 \\
\hline valve & designation & note \\
\hline 1. BP overflow & 1(2)B-37, 29, 30 & \\
\hline 2. drain from concrete cantilever & $\begin{array}{l}\text { 1(2)SK-25/1 } \\
1(2) B-30 \\
1 \mathrm{~B}-34\end{array}$ & \\
\hline $\mathrm{KB}$ & $\begin{array}{l}\text { 1(2)SK-23, 24, 2K-7, 2B-86, } \\
1 \mathrm{~K}-7,1 \mathrm{~B}-8\end{array}$ & \\
\hline 4. relief from $\mathrm{KB}$ to $\mathrm{V}-3$ & $\begin{array}{l}\text { 1(2)A29/1, 3, [illegible] air } \\
\text { line }\end{array}$ & \\
\hline 5. NBS delivery & $1(2) \mathrm{B}-12 / 1,2,3$ & \\
\hline 6. delivery $2 \mathrm{NDI}-1$ (in room A-102/1) & & \\
\hline 7. drain from $2 \mathrm{ShA}$ & 2 SK-27 & \\
\hline 8. drain of R-1 and B-004 boxes & & \\
\hline 9. pipeline from $20 \mathrm{~V} 0-1$ to $\mathrm{B}-8$ & $2 \mathrm{U} 1-40$ & \\
\hline 10. TOP pipeline & $1(2) R-35$ & \\
\hline 11. SVO-1 drains & $\begin{array}{l}1 U 1-13 / 1 \\
2 U 1-20 / 1\end{array}$ & \\
\hline 12. All samplers & & \\
\hline \multicolumn{3}{|c|}{ Ventilation } \\
\hline 13. pressure valve of $R-2$ system & $1(2) \mathrm{D}-2$ & \\
\hline 14. pressure valve of fan $V-1-1$ & $1(2) G-1$ & \\
\hline 15. pressure valves of V-2 system & $\begin{array}{l}1(2) \mathrm{A}-2 / 1,2,3,4,2 \mathrm{~A}-2 / 5,6, \\
7,8\end{array}$ & \\
\hline $\begin{array}{l}\text { 16. all steam and water cut-off valves of } \\
\text { system V-2 }\end{array}$ & & \\
\hline 17. gate valves on ventilators $P-4-1$ (2) & & \\
\hline
\end{tabular}




\begin{tabular}{|c|c|c|}
\hline 18. pressure valves of $V-4$ system & $\begin{array}{l}1(2) \mathrm{A}-4 / 1,2,3,4,2 \mathrm{~A}-5 / 5,6 \text {, } \\
7\end{array}$ & \\
\hline \multicolumn{3}{|l|}{ 19. rotary valve on V-4 system } \\
\hline $\begin{array}{l}\text { 20. valves for constant and periodic aerosol } \\
\text { monitoring of } G O\end{array}$ & & \\
\hline 20a. prèssure valves of system $2 \mathrm{P}-4$ & $2 \mathrm{P}-4 / 1,2$ & \\
\hline $20 \mathrm{~b}$. pressure valves of system P- 6 & A- $-6 / 3,4$ & \\
\hline \multicolumn{3}{|c|}{ Special waste water disposal system } \\
\hline $\begin{array}{l}\text { 21. trap from main circulating pump deck } \\
\text { (rooms A-102/1, 2) and from sluice (A- } \\
103 / 1,2 \text { ) }\end{array}$ & $1 S K-10$ & \\
\hline $\begin{array}{l}\text { 22. traps in monitoring instrumentation } \\
\text { room (room } A-004 / 1,2 \text { ) }\end{array}$ & & \\
\hline $\begin{array}{l}\text { 23. trap in ventilation chamber area of } \\
\text { primary loop (room A-013/1 (2)) }\end{array}$ & & \\
\hline 24. trap in corridor A-306/1 (2) & & \\
\hline \multicolumn{2}{|l|}{$\begin{array}{l}\text { 25. trap in feed maintenance deaerator room } \\
\text { (room A-303/1 (2)) }\end{array}$} & \\
\hline 26. trap from $\mathrm{R}-1$ boxes & $\begin{array}{l}\text { ISK-30, } 31 \\
2 \mathrm{SK}-29\end{array}$ & \\
\hline 27. trap in $\begin{array}{r}\mathrm{A}-010 / 1 \\
\mathrm{~A}-011 / 2\end{array}$ & & \\
\hline \multicolumn{2}{|l|}{$\begin{array}{l}\text { 28. trap in sampling room of plant } 1 \mathrm{~A} \text { - } \\
311 / 1 \text { (2) }\end{array}$} & \\
\hline $\begin{array}{l}\text { 29. relief, overflow and sampler valves, air } \\
\text { lines } 1(2) \mathrm{KB} \text {. }\end{array}$ & & \\
\hline $\begin{array}{l}\text { 30. valves on head } 1 N D R-1 \text { in room A- } \\
102 / 1\end{array}$ & & \\
\hline
\end{tabular}




\section{PROCEDURE FOR PROCESSING TEST RESULTS}

The calculation of the leakage value is performed from the measurement results according to the formula (1):

$$
\mathrm{L}_{\mathrm{m}}=(2400 / \Delta z)\left(1-\mathrm{P}_{\mathrm{i}+1} / \mathrm{P}_{\mathrm{i}}\right)
$$

where $\mathrm{L}_{\mathrm{m}}$ is the leakage value, in \% per day;

$\mathrm{P}_{\mathrm{i}}$ and $\mathrm{P}_{\mathrm{i}+1}$ are the absolute air pressure in the pressurized space at the measurement times $\mathrm{z}$ and $\mathrm{z}_{\mathrm{i}+1}$, in $\mathrm{kg} / \mathrm{m}^{2}$;

$\mathrm{Lz}=\mathrm{z}_{\mathrm{i}+1}-\mathrm{z}_{\mathrm{i}}$ represents the time between measurements, in hours;

$\mathrm{i}=1$ to $\mathrm{n}$, where $\mathrm{n}$ is the number of measurements in the time interval $z_{n}-z_{i}$ ).

The value of the absolute air pressure in the GO $P_{2 b s i}$ is computed as the sum of the measured values of the positive pressure $P_{\text {posi }}$ and the barometric pressure $B_{i}$ (according to data of the weather station):

$$
\begin{aligned}
& P_{\text {absi }}=P_{\text {posi }}+B_{i} \\
& P_{\text {posi }}=\left(j \text { to } \cap P_{\text {posj }}\right) / K
\end{aligned}
$$

where $\mathrm{K}$ is the number of pressure gauges;

$P_{\text {posj }}$ represents the readings of each of them at the time of measurement. 


\section{IS T}

of standard openings which isolate the containment building system

\begin{tabular}{|c|c|c|}
\hline Item & quantity & Adjacent rooms \\
\hline \multicolumn{3}{|l|}{ 1. hatches of central hall: } \\
\hline $\begin{array}{l}\text { - over main circulating pumps } \\
\text { - over steam generators } \\
\text { - over SVO-1 filters } \\
\text { - over SVO-1 solid waste } \\
\text { - transportation opening }\end{array}$ & $\begin{array}{l}6 \\
6 \\
1 \\
1 \\
1\end{array}$ & $\begin{array}{l}\text { A-102/1, 2-A-301 } \\
\text { A-002/1, 2-A-301 } \\
\text { A-207/1, 2-A-301 } \\
\text { A-206/1, 2-A-301 } \\
\text { A-002/1, 2-A-301 }\end{array}$ \\
\hline \multicolumn{3}{|l|}{ 2. hatches of R-1 system: } \\
\hline $\begin{array}{l}\text { - above air coolers } \\
\text { - above pressure valves } \\
\text { - diameter } 600 \text { above air lines } \\
\text { - diameter } 500 \text { into inlet box }\end{array}$ & $\begin{array}{l}10 \\
5 \\
5 \\
1\end{array}$ & $\begin{array}{c}\mathrm{V}-007 / 1,2 \\
-"- \\
-"- \\
\mathrm{V}-007 / 1-\mathrm{V}=004 / 1 \\
\end{array}$ \\
\hline 3. reactor cover with process flange & 1 & \\
\hline \multicolumn{3}{|l|}{ 4. room doors: } \\
\hline $\begin{array}{l}\text {-A-004/1, } \\
\text { - A-004/2,4 } \\
\text { - V-007/2 } \\
\text { - A-011/1,2 } \\
\text { - A-013/1,2 } \\
\text { - A-103/1,2 } \\
\text { - A-102/1,2 } \\
\text { - A-002/1,2 } \\
\text { - A-101/1,2 } \\
\text {-A-106/1,2 } \\
\text { - A-201/1,2 } \\
\text { - A-204/1,2 } \\
\text {-A-205/1,2 } \\
\text { - A-308/1,2 } \\
\text { - A-502/1,2 }\end{array}$ & $\begin{array}{l}1 \\
1 \\
1 \\
1 \\
1 \\
1 \\
1 \\
1 \\
1 \\
1 \\
1 \\
1 \\
1 \\
1 \\
1\end{array}$ & 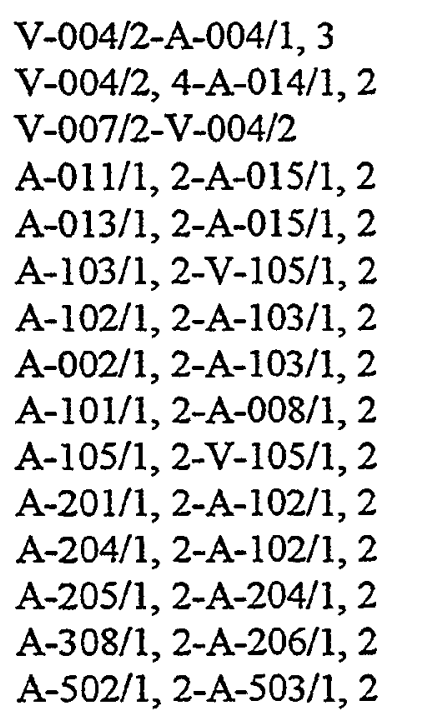 \\
\hline
\end{tabular}


Patrol routes for containment building in integrated tests

\begin{tabular}{|c|c|}
\hline 1 & 2 \\
\hline Room & Inspection objects \\
\hline \multicolumn{2}{|r|}{ Mark - 1.80} \\
\hline $\mathrm{V}-004$ & $\begin{array}{l}\text { cable, pulse and process passages, pressure door to room A-004/3; stopper } \\
\text { valves - quantity } 2 \text {; pressure door to inlet box }\end{array}$ \\
\hline V-007 & $\begin{array}{l}\text { cable and pulse passages, } 10 \text { hatches under air coolers, pressure door to } \\
\text { delivery box }\end{array}$ \\
\hline V-005 & seals of $R-1$ fan shafts (quantity 5), 5 round hatches in walls in row G \\
\hline V-010 & cable and pulse passages, valve trap \\
\hline V-009 & process and pulse passages \\
\hline A-011 & pulse passages \\
\hline A-015 & $\begin{array}{l}\text { pressure door to } A-013 / 2 \text {, process and pulse passages, cable passages above } \\
\text { door to } A-013 / 2\end{array}$ \\
\hline A-014 & pressure door to room A-004/4, cable, pulse and process passages \\
\hline \multicolumn{2}{|r|}{ Mark 0.00 and +2.70} \\
\hline$V-105$ & $\begin{array}{l}\text { pressure doors to rooms } A-103 / 2 \text { and } A-105 / 2 \text {, cable, pulse and process } \\
\text { passages }\end{array}$ \\
\hline A-107 & process and pulse passages, backup stoppers, stem passages \\
\hline A-108 & process, pulse and cable passages, pressure door to room A-101/2 \\
\hline V-104 & pressure door to room A-104/2 \\
\hline $\begin{array}{l}E-102 \\
E-107\end{array}$ & passage of any type \\
\hline \multicolumn{2}{|r|}{ Mark +5.40 and +6.30} \\
\hline V-209 & cable passages in wall in row "G" E-3 \\
\hline$V-203$ & $\begin{array}{l}\text { cable passages of main circulating pump cables (quantity 2), passages E382, } \\
383,381,384,388,380,379,378 \text { and } 377\end{array}$ \\
\hline$A-210$ & cable passages E77 \\
\hline
\end{tabular}




\begin{tabular}{||l|l|}
\hline V-214 & process passages \\
\hline A-008 & cable passages E-304, E-305 (entrance from A-203) \\
\hline E-202 & passages of all types \\
\hline A-214 & process passages in pipeline corridor from room A-206/2 \\
\hline \multicolumn{1}{|c|}{ Mark +9.60 and 10.50 } \\
\hline A-301 & $\begin{array}{l}\text { hatches above steam generators and main circulating pumps, backup passages, } \\
\text { reactor cover }\end{array}$ \\
\hline A-302 & overflow valves, quantity 9 \\
\hline A-306 & cable passages E-205 \\
\hline \multicolumn{2}{|l|}{ Mark +14.7 } \\
\hline A-503 & cable (E-219), pulse and process passages; pressure door to room A-502/2 \\
\hline E-401 & process passages of main steam pipelines and feeder pipelines \\
\hline
\end{tabular}


ATTACHMENT 5

Results of Leaktightness Testing for Kola Unit 2 (5/96)

(English and Russian) 


\section{$\mathbf{F} \mathbf{A} \mathbf{X}$}

\begin{tabular}{|ll|}
\hline 1. To: & Yu. V. Kon'yev \\
\hline Company: & REA Concern \\
\hline Telephone: & (095)220-64-30 \\
\hline Fax: & $(095) 220-63-64$ \\
\hline 2. To: & Dr. George A. Greene \\
\hline Company: & Director BNL (USA) \\
\hline Telephone: & 516-344-2296 \\
\hline Fax: & $516-344-3526$ \\
\hline
\end{tabular}

\begin{tabular}{|ll|}
\hline From: & \\
\hline & V. V. Omel'chuk \\
\hline & Chief Engineer \\
\hline Telephone: & $(815-32)-68-351$ \\
\hline Fax: & $(815-32)-68-140$ \\
\hline Date: & 31 May 1996 \\
\hline Reference Number: & $11 / 8-249$ \\
\hline No. pp. incl. cover: & 7 \\
\hline
\end{tabular}

concerning the forwarding of the test certificate for the system of pressurized rooms of unit 2.

\section{Gentlemen:}

Per your request, I am sending certificate 55-96/TsNIP for the testing of the system of pressurized rooms of unit 2 of the Kola Nuclear Power Plant conducted after preventive maintenance PPR96.

Attachment: 1. Certificate 55-96/TsNIP, 6 pages, to each address.

Respectfully,

Chief Engineer
V. V. Omel'chuk 
APPROVED

Chief Engineer, Kola NPP

[signature] V. V. Omel'chuk

30 May 1996

Kola Nuclear Power Plant

Certificate 55-96/TsNIP

Kola NPP, unit 2

25 - 27 May 1996

Reactor Department

Design component: system of pressurized rooms (SGP)

Reference document: working program 1.2-11-20PG-94

A committee made up of the following

deputy director, TsNIP

[setup, testing and startup department]

supervisor of GLSB, TsNIP

engineer, reactor department

S. V. Gorelikhin

T. I. Petkevich

V. V. Sborovskiy

tested the integrity of the system of pressurized rooms and obtained the following results.

\begin{tabular}{|c|c|c|c|c|}
\hline Test & $\begin{array}{l}\text { Program } \\
\text { item }\end{array}$ & $\begin{array}{l}\text { Test criteria (results of } \\
\text { previous tests after } \\
\text { preventive maintenance } \\
\text { PPR-94) }\end{array}$ & Result & Conclusion \\
\hline $\begin{array}{l}\text { 1. Vacuum test of } \\
\text { SGP }\end{array}$ & item 8.1 & $\begin{array}{l}\text { Vacuum in SGP, } \\
199 \mathrm{mmH}_{2} \mathrm{O}\end{array}$ & $\begin{array}{l}\text { Vacuum in SGP, } \\
226 \mathrm{mmH}_{2} \mathrm{O}\end{array}$ & Satisfactory \\
\hline $\begin{array}{l}\text { 2. Pressurization of } \\
\text { SGP }\end{array}$ & $\begin{array}{l}\text { item } 8.2 \\
-\end{array}$ & $\begin{array}{c}\text { Pressure achieved in } \\
\text { SGP, } 70 \mathrm{mmH}_{2} \mathrm{O} \text {; } \\
\text { Leakage } L=4950 \% \text { of } \\
\text { volume per day } \\
\text { (for } \mathrm{P}=0.5 \text { atm gauge); } \\
\text { Leak equivalent } \\
\text { diameter } \mathrm{De}=366 \mathrm{~mm}\end{array}$ & $\begin{array}{l}\text { Pressure achieved in } \\
\text { SGP, } 275 \mathrm{mmH}_{2} \mathrm{O} \text {; } \\
\text { Leakage } L=768 \% \text { of } \\
\text { volume per day } \\
\text { (for } \mathrm{P}=0.5 \text { atm gauge); } \\
\text { Leak equivalent } \\
\text { diameter } \mathrm{De}=192 \mathrm{~mm}\end{array}$ & Satisfactory \\
\hline
\end{tabular}

\section{Course of tests}

The testing was conducted in two stages: vacuum testing and pressurization testing.

1.1. Vacuum testing: the SGP [system of pressurized rooms] was prepared for the tests in accordance with the specifications of the testing program. Personnel of the TsNIP [setup, testing and startup department] and repair personnel of the TsTsR [centralized repair shop], TsTAI [thermal automation and measurement department], ETs [electrical shop] and KRU, Kola NPP, were admitted to the pressurized area to look for defects. A vacuum was created in the pressurized enclosure by the operation of two fans of the $2 \mathrm{~B}-4$ system (overall flow rate $\mathrm{Q}=80,000 \mathrm{~m}^{3} / \mathrm{h}$ ). The vacuum level was monitored with a $U$-shaped pressure gauge situated on a pulse pressure measurement tube in the steam generator box. 
Several dozen flaws were discovered in the pressure lining, passages and hatch and door seals in the course of the vacuum testing; the flaws basically were eliminated within a day by the repair personnel. Supplementary vacuum testing to confirm the elimination of the defects and possibly to detect new ones was performed before the pressurization testing. At the conclusion of vacuum testing, the pressure valves of ventilation system $2 B-4$ in steam generator box $2 A-4 / 6,7$ were closed, and the vacuum drop time was monitored.

1.2. Pressurization testing: the SGP was prepared for tests in accordance with the specifications of the testing program. A positive pressure was created in the pressurized enclosure by the operation of a compressor to test the pressurized enclosure of the reactor units of phase 2. The pressure was monitored with two pressure gauges with a scale of $0-1 \mathrm{~kg} / \mathrm{cm}^{2}$ and an accuracy class of 0.4 situated on pressure measurement tubes in the steam generator box.

Because of the inadequate capacity of the compressor and the relatively great extent of the pressurization system, the pressure in the sealed enclosure reached $\mathrm{P}=275 \mathrm{mmH}_{2} \mathrm{O}$. An outside inspection of the SGP was performed at this pressure, and the amount of leakage from the GO [pressurized enclosure] was determined after the compressor had been turned off.

\section{Conclusions}

2.1. The test results are in conformity with the criteria.

2.2. The defects cited in Annex 1 were detected in the course of the tests.

$$
\begin{array}{ll}
\text { [signed] } & \text { S. V. Gorelikhin } \\
\text { [signed] } & \text { T. I. Petkevich } \\
\text { [signed] } & \text { V. V. Sborovskiy }
\end{array}
$$

3. Conclusion

3.1. The integrity of the system of pressurized rooms (SGP) has been enhanced substantially due to the execution of a set of actions during preventive maintenance PPR-96.

3.2. The system of pressurized rooms is hereby cleared for further operation.

3.3. The defects discovered are to be eliminated in accordance with Annex 1. The parties responsible are: the centralized repair shop (TsTsR), the thermal automation and measurement department (TsTAI), the electrical shop (ETs) and the TsEOO (according to affiliation).

3.4. Measures are to be developed for the further enhancement of the integrity of the SGP.

Party responsible: setup, testing and startup department (TsNIP); Deadline: June 1996.

Head of Reactor Department [signed]

Head of Setup, Testing and Startup Depariment [signed]

G. S. Paradnikov 
LIST OF DEFECTS OF THE PRESSURIZED ENCLOSURE OF UNTT 2 DISCOVERED DURING TESTS OF THE ENCLOSURE AFTER PREVENTIVE MAINTENANCE PPR-96

\begin{tabular}{|c|c|c|c|}
\hline 1 & 2 & 3 & 4 \\
\hline Item & Room & $\begin{array}{c}\text { Party } \\
\text { responsible for } \\
\text { execution }\end{array}$ & Execution deadline \\
\hline \multicolumn{4}{|l|}{$\begin{array}{l}\text { DISCOVERED DURING VACUUM } \\
\text { TESTING }\end{array}$} \\
\hline $\begin{array}{l}\text { 1. Lining defect (at the top under the } \\
\text { entry door) }\end{array}$ & A- $105 / 2$ & $\because$ & $\begin{array}{l}\text { eliminated after } \\
\text { vacuum testing }\end{array}$ \\
\hline $\begin{array}{l}\text { 2. Lack of fusion penetration in lining in } \\
\text { floor behind RTO }\end{array}$ & A-206/2 & & $\begin{array}{l}\text { eliminated after } \\
\text { vacuum testing }\end{array}$ \\
\hline 3. Leakage under pulse tubes behind RTO & A-206/2 & & $\begin{array}{l}\text { eliminated after } \\
\text { vacuum testing }\end{array}$ \\
\hline 4. Lining flaw behind platform in wall & $\mathrm{A}-207 / 2$ & $\begin{array}{l}\text { Centralized } \\
\text { repair shop } \\
\text { (TsTsR) }\end{array}$ & $\begin{array}{l}\text { before startup of } \\
\text { the unit }\end{array}$ \\
\hline $\begin{array}{l}\text { 5. Lining flaw at point of weld of } \\
\text { suspension (left remote) to ceiling }\end{array}$ & $\mathrm{A}-002 / 2$ & & $\begin{array}{l}\text { eliminated after } \\
\text { vacuum testing }\end{array}$ \\
\hline $\begin{array}{l}\text { 6. Lining defect on cable shaft by steam } \\
\text { generator PG-1 }\end{array}$ & $\mathrm{A}-002 / 2$ & & $\begin{array}{l}\text { eliminated after } \\
\text { vacuum testing }\end{array}$ \\
\hline $\begin{array}{l}\text { 7. Lining defect on cable shaft by steam } \\
\text { generator PG-6 }\end{array}$ & $\mathrm{A}-002 / 2$ & & $\begin{array}{l}\text { eliminated after } \\
\text { vacuum testing }\end{array}$ \\
\hline $\begin{array}{l}\text { 8. Lining defect on wall behind steam } \\
\text { generator PG-6 (at inlet of pipeline) }\end{array}$ & $\mathrm{A}-002 / 2$ & & $\begin{array}{l}\text { eliminated after } \\
\text { vacuum testing }\end{array}$ \\
\hline $\begin{array}{l}\text { 9. Two lining defects on wall behind } \\
\text { steam generator PG-5 }\end{array}$ & $\mathrm{A}-002 / 2$ & & $\begin{array}{l}\text { eliminated after. } \\
\text { vacuum testing }\end{array}$ \\
\hline
\end{tabular}




\begin{tabular}{|c|c|c|c|}
\hline $\begin{array}{l}\text { 10. Lining defect on wall between steam } \\
\text { generator } P G-4 \text { and steam generator PG-5 }\end{array}$ & $A-002 / 2$ & TsTsR & $\begin{array}{l}\text { before startup of } \\
\text { the unit }\end{array}$ \\
\hline $\begin{array}{l}\text { 11. Lining defect of vertical pipeline } \\
\text { passage behind steam generator PG-1 (to } \\
\text { the right of ladder) }\end{array}$ & $A-002 / 2$ & TsTsR & $\begin{array}{l}\text { before startup of } \\
\text { the unit }\end{array}$ \\
\hline $\begin{array}{l}\text { 12. Leak on pulse line Dy } 100 \text { (metering) } \\
\text { and along lining separation between KZV } \\
\text { [exhaust stopper valve] K-11/23 inlet and } \\
\text { lining behind steam generator PG-3 (under } \\
\text { GK service platform) }\end{array}$ & $\mathrm{A}-002 / 2$ & TsTsR & $\begin{array}{l}\text { before startup of } \\
\text { the unit }\end{array}$ \\
\hline 13. Leak on inlet passage Dy15 & A-101/2 & & $\begin{array}{l}\text { eliminated after } \\
\text { vacuum testing }\end{array}$ \\
\hline 14. Lining defect on wall at mark 4.5 & A-101/2 & & $\begin{array}{l}\text { eliminated after } \\
\text { vacuum testing }\end{array}$ \\
\hline 15. Lining defect in comer behind channel & $\begin{array}{l}\text { A-101/2 } \\
\text { (top) }\end{array}$ & & $\begin{array}{l}\text { eliminated after } \\
\text { vacuum testing }\end{array}$ \\
\hline $\begin{array}{l}\text { 16. Leak in door seal from A-101/2 to } \\
\text { A-107/2 }\end{array}$ & $A-101 / 2$ & TsTsR & $\begin{array}{l}\text { before startup of } \\
\text { the unit }\end{array}$ \\
\hline 17. Leak on inlet passage Dy20 & A-502/2 & & $\begin{array}{l}\text { eliminated after } \\
\text { vacuum testing }\end{array}$ \\
\hline 18. Leak on inlet steam lines & A- $-002 / 2$ & TsTsR & $\begin{array}{c}\text { preventive } \\
\text { maintenance PPR- } \\
97 \\
\end{array}$ \\
\hline $\begin{array}{l}\text { 19. Defect on main circulating pump } \\
\text { (GTsK) support (cold fine) of loop } 1\end{array}$ & A-002/2 & & $\begin{array}{l}\text { eliminated after } \\
\text { vacuum testing }\end{array}$ \\
\hline $\begin{array}{l}\text { 20. Leak along pipeline Dy200 (at floor) } \\
\text { by } 2 P-2 / 6\end{array}$ & $\begin{array}{l}\text { A-102/2 } \\
\text { (inner } \\
\text { wall) }\end{array}$ & & $\begin{array}{l}\text { eliminated after } \\
\text { vacuum testing }\end{array}$ \\
\hline 21. Leak on cable passage & A-103/2 & & $\begin{array}{l}\text { eliminated after } \\
\text { vacuum testing }\end{array}$ \\
\hline $\begin{array}{l}\text { 22. Leaks in seal of operation hatch and } \\
\text { hatch above } 2 \mathrm{GTsN}-4\end{array}$ & & & $\begin{array}{c}\text { preventive } \\
\text { maintenance PPR- } \\
97\end{array}$ \\
\hline $\begin{array}{l}\text { 23. Leak in floor (bordering on room A- } \\
004 / 3 \text { ) }\end{array}$ & $\mathrm{A}-002 / 2$ & & $\begin{array}{l}\text { eliminated after } \\
\text { vacuum testing }\end{array}$ \\
\hline
\end{tabular}




\begin{tabular}{|c|c|c|c|}
\hline $\begin{array}{l}\text { 24. Gas pocket under connecting platform } \\
\text { in room } A-013 / 2\end{array}$ & $\mathrm{~A}-002 / 2$ & & $\begin{array}{l}\text { eliminated after } \\
\text { vacuum testing }\end{array}$ \\
\hline $\begin{array}{l}\text { 25. Gas pocket in weld at joining of floor } \\
\text { and wall of room } A-013 / 2 \text { (to right of } \\
\text { entrance) }\end{array}$ & A-002/2 & & $\begin{array}{l}\text { eliminated after } \\
\text { vacuum testing }\end{array}$ \\
\hline $\begin{array}{l}\text { 26. Defect by passage in wall in room A- } \\
012 / 2 \text { at floor level }\end{array}$ & A-002/2 & & $\begin{array}{l}\text { eliminated after } \\
\text { vacuum testing }\end{array}$ \\
\hline $\begin{array}{l}\text { 27. Weld defect on support of pipeline } \\
\text { Dy500 of cold line, loop } 1\end{array}$ & $\mathrm{~A}-002 / 2$ & & $\begin{array}{l}\text { eliminated after } \\
\text { vacuum testing }\end{array}$ \\
\hline $\begin{array}{l}\text { 28. Weld defect on face of support prop } \\
\text { under } 2 \mathrm{PG}-6\end{array}$ & $\mathrm{~A}-002 / 2$ & & $\begin{array}{l}\text { eliminated after. } \\
\text { vacuum testing }\end{array}$ \\
\hline 29. Gas pocket on wall of cable shaft & $\mathrm{A}-002 / 2$ & & $\begin{array}{l}\text { eliminated after } \\
\text { vacuum testing }\end{array}$ \\
\hline $\begin{array}{l}\text { 30. Ceiling lining defect next to KZV K- } \\
11 / 24 \text { and } \mathrm{K}-11 / 25\end{array}$ & $\mathrm{~A}-002 / 2$ & TsTsR & $\begin{array}{l}\text { before startup of } \\
\text { the unit }\end{array}$ \\
\hline $\begin{array}{l}\text { 31. Lining defect by gangway }(1.5 \mathrm{~m} \text { from } \\
\text { floor) }\end{array}$ & $\begin{array}{r}\mathrm{A}-013 / 2 \\
.\end{array}$ & & $\begin{array}{l}\text { eliminated after } \\
\text { vacuum testing }\end{array}$ \\
\hline $\begin{array}{l}\text { 32. Weld defect on frame of opening } \\
\text { between room } A-013 / 2 \text { and SVO-1 }\end{array}$ & $\mathrm{A}-013 / 2$ & & $\begin{array}{l}\text { eliminated after } \\
\text { vacuum testing }\end{array}$ \\
\hline 33. Weld defect in lining of gangway & $\mathrm{A}-013 / 2$ & & $\begin{array}{l}\text { before startup of } \\
\text { the unit }\end{array}$ \\
\hline 34. Leak on pulse tube inlet & $\mathrm{A}-001 / 2$ & & $\begin{array}{l}\text { eliminated after } \\
\text { vacuum testing }\end{array}$ \\
\hline $\begin{array}{l}\text { 35. Leaks on hatches Dy } 800 \text { of system } R \text { - } \\
1-2,3,4,5\end{array}$ & B-009/2 & TsEOO & $\begin{array}{l}\text { before startup of } \\
\text { the unit }\end{array}$ \\
\hline $\begin{array}{l}\text { 36. Weid defect around pulse tube above } \\
\text { KIP box (SIR-324) opposite } 2 \mathrm{P}-2 / 6\end{array}$ & A-102/2 & & $\begin{array}{l}\text { eliminated after } \\
\text { vacuum testing }\end{array}$ \\
\hline 37. Weld defect around $2 \mathrm{P}-1 / 4,2 / 2,1 / 2$ & A-102/2 & TsTsR & $\begin{array}{l}\text { before startup of } \\
\text { the unit }\end{array}$ \\
\hline $\begin{array}{l}\text { 38. Lining burn-through at point of weld } \\
\text { of hoist beam between loops } 2 \text { and } 3\end{array}$ & A-102/2 & & $\begin{array}{l}\text { eliminated after } \\
\text { vacuum testing }\end{array}$ \\
\hline
\end{tabular}




\begin{tabular}{|l|c|c|c|}
\hline $\begin{array}{l}\text { 39. Defect on abutment of KID [pressure } \\
\text { relief valve] inlet with pressure lining (2.5 } \\
\text { right of door, last on left) }\end{array}$ & $\begin{array}{c}\text { circular } \\
\text { corridor } \\
211-4\end{array}$ & $\begin{array}{c}\text { eliminated after } \\
\text { vacuum testing }\end{array}$ \\
\hline $\begin{array}{l}\text { 40. Leak on section under reactor cover } \\
\text { of transportation passage from BV [spent } \\
\text { fuel pool] to BP }\end{array}$ & TsTsR & $\begin{array}{c}\text { preventive } \\
\text { maintenance PPR- } \\
97\end{array}$ \\
\hline $\begin{array}{l}\text { 41. In room A-015/5, cut and seal pipe } \\
\text { Dy32 (in room A-002/2, the pipe passes } \\
\text { around the ring of the reactor shaft at a } \\
\text { height of } 1.5 \text { m from the floor) }\end{array}$ & TsTsR & $\begin{array}{c}\text { preventive } \\
\text { maintenance PPR- } \\
97\end{array}$ \\
\hline $\begin{array}{l}42 . \text { Numerous lining defects in reactor } \\
\text { shaft under cantilever }\end{array}$ & TsTsR & $\begin{array}{c}\text { preventive } \\
\text { maintenance PPR- } \\
97\end{array}$ \\
\hline
\end{tabular}




\begin{tabular}{|c|c|c|c|}
\hline 1 & 2 & 3 & 4 \\
\hline \multicolumn{4}{|l|}{$\begin{array}{l}\text { DISCOVERED IN PRESSURIZATION } \\
\text { TESTING }\end{array}$} \\
\hline 1. Leak on gangway lining & A-303/2 & TsTsR & $\begin{array}{l}\text { before startup of } \\
\text { the unit }\end{array}$ \\
\hline $\begin{array}{l}\text { 2. Leak on pulse passage (left of door to } \\
\text { room } A-308 / 2 \text { ) }\end{array}$ & A-306/2 & $\begin{array}{l}\text { thermal } \\
\text { automation } \\
\text { and } \\
\text { measurement } \\
\text { department } \\
\text { (TsTAI) }\end{array}$ & $\begin{array}{l}\text { before startup of } \\
\text { the unit }\end{array}$ \\
\hline $\begin{array}{l}\text { 3. Leak on } 2 \mathrm{PG}-3 \text { constant ventilation } \\
\text { passage }\end{array}$ & A- $-014 / 2$ & TsTsR & $\begin{array}{l}\text { before startup of } \\
\text { the unit }\end{array}$ \\
\hline $\begin{array}{l}\text { 4. Leak on } \mathrm{KIP} \text { passage by } 2 \mathrm{PG}-4,5 \\
\text { constant ventilation passage }\end{array}$ & A-014/2 & TsTsR & $\begin{array}{l}\text { before startup of } \\
\text { the unit }\end{array}$ \\
\hline 5. Leak in gangway weld & B-007/2. & TsTsR & $\begin{array}{c}\text { preventive } \\
\text { maintenance } \\
\text { PPR-97 }\end{array}$ \\
\hline $\begin{array}{l}\text { 6. Leak around circumference of air inlet } \\
\text { passage (in right wall) }\end{array}$ & $\begin{array}{l}\text { B-210/2 } \\
\text { (second } \\
\text { room) }\end{array}$ & TsTsR & $\begin{array}{c}\text { preventive } \\
\text { maintenance } \\
\text { PPR-97 }\end{array}$ \\
\hline $\begin{array}{l}\text { 7. Leak in Dy800 hatch seal ( } 4 \text { from } \\
\text { entrance) }\end{array}$ & B-008/2 & TsEOO & $\begin{array}{l}\text { before startup of } \\
\text { the unit }\end{array}$ \\
\hline $\begin{array}{l}\text { 8. Leak in rectangular hatch seal ( } 2 \text { and } 4 \\
\text { from entrance) }\end{array}$ & B-008/2 & TsEOO & $\begin{array}{l}\text { before startup of } \\
\text { the unit }\end{array}$ \\
\hline $\begin{array}{l}\text { 9. Leaks in gland seal of ventilator shafts } \\
2 \mathrm{R}-1-3,4,5\end{array}$ & B-005/2 & TsEOO & $\begin{array}{c}\text { preventive } \\
\text { maintenance } \\
\text { PPR-97 (assemble } \\
\text { face seals) }\end{array}$ \\
\hline $\begin{array}{l}\text { 10. Leaks around circumference of } \\
\text { protective plates of ventilator system 2P-1 }\end{array}$ & & TsEOO & $\begin{array}{c}\text { preventive } \\
\text { maintenance } \\
\text { PPR-97 }\end{array}$ \\
\hline
\end{tabular}




\begin{tabular}{|l|c|c|c|}
\hline $\begin{array}{l}\text { 11. KIP control valve (backup line P) out } \\
\text { of order at gate valve 21-17/4 }\end{array}$ & B-005/2 & TsTAI & \multicolumn{1}{c|}{$\begin{array}{c}\text { preventive } \\
\text { maintenance } \\
\text { PPR-97 }\end{array}$} \\
\hline $\begin{array}{l}\text { 12. Leaks in two cable passages (45-46, } \\
\text { for example) }\end{array}$ & A-203/2 & TsTAI & $\begin{array}{c}\text { before startup of } \\
\text { the unit }\end{array}$ \\
\hline $\begin{array}{l}\text { 12. Leak in cable passage (47, for } \\
\text { example) }\end{array}$ & A-008/2 & TsTAI & $\begin{array}{c}\text { before startup of } \\
\text { the unit }\end{array}$ \\
\hline $\begin{array}{l}\text { 13. Leak in cable passage (48, for } \\
\text { example) }\end{array}$ & A-008/2 & TsTAI & $\begin{array}{c}\text { before startup of } \\
\text { the unit }\end{array}$ \\
\hline 14. Leak in KIP inlet passage & A-012/2 & TsTsR & $\begin{array}{c}\text { before startup of } \\
\text { the unit }\end{array}$ \\
\hline 15. Leak in gangway lining & A-303/2 & TsTsR & $\begin{array}{c}\text { before startup of } \\
\text { the unit }\end{array}$ \\
\hline
\end{tabular}




\section{F A X}

\begin{tabular}{|ll|}
\hline 1. To: & Yu. V. Kon'yev \\
\hline Company: & REA Concenn \\
\hline Telephone: & $(095) 220-64-30$ \\
\hline Fax: & $(095) 220-63-64$ \\
\hline 2. To: & Dr. George A. Greene \\
\hline Company: & Director BNL. (USA) \\
\hline Telephone: & 516-344-2296 \\
\hline Fax: & $516-344-3526$ \\
\hline & \\
\hline
\end{tabular}

\begin{tabular}{|ll|}
\hline From: & \\
\hline & V. V. Omel'chuk \\
\hline & Chief Engineer \\
\hline Telephone: & $(815-32)-68-351$ \\
\hline Fax: & $(815-32)-68-140$ \\
\hline Date: & 31 May 1996 \\
\hline Reference Number: & $11 / 8-249$ \\
\hline No. pp. incl. cover: & 7 \\
\hline & \\
\hline
\end{tabular}

concerning the forwarding of the test certificate for the system of pressurized rooms of unit 2 .

\section{Gentlemen:}

Per your request, I am sending certificate 55-96/TsNIP for the testing of the system of pressurized rooms of unit 2 of the Kola Nuclear Power Plant conducted after preventive maintenance PPR96.

Attachment: 1. Certificate $55-96 / \mathrm{TsNIP}, 6$ pages, to each address.

Respectfully,

Chief Engineer

[signed]

V. V. Omel'chuk

$$
\begin{aligned}
& f=\text { cervectoons made } \\
& \text { befre June lago } \\
& \text { restont of Uma } 2
\end{aligned}
$$


APPROVED

Chief Engineer, Kola NPP

[signature] V. V. Omel'chuk

30 May 1996

Kola Nuclear Power Plant

Certificate 55-96/TsNIP

Kola NPP, unit 2

25 - 27 May 1996

Reactor Department

Design component: system of pressurized rooms (SGP)

Reference document: working program 1.2-11-20PG-94

A committee made up of the following

deputy director, TsNIF

[setup, testing and startup department]

supervisor of GLSB, TsNIP

engineer, reactor department

S. V. Gorelikhin

T. I. Petkevich

V. V. Sborovskiy

tested the integrity of the system of pressurized rooms and obtained the following results.

\begin{tabular}{|c|c|c|c|c|}
\hline Test & $\begin{array}{c}\text { Program } \\
\text { item }\end{array}$ & $\begin{array}{l}\text { Test criteria (results of } \\
\text { previous tests after } \\
\text { preventive maintenance } \\
\text { PPR-94) }\end{array}$ & Result & Conclusion \\
\hline $\begin{array}{l}\text { 1. Vacuum test of } \\
\text { SGP }\end{array}$ & item 8.1 & $\begin{array}{l}\text { Vacuum in SGP, } \\
199 \mathrm{mmH}_{2} \mathrm{O}\end{array}$ & $\begin{array}{l}\text { Vacuum in SGP, } \\
226 \mathrm{mmH}_{2} \mathrm{O}\end{array}$ & Satisfactory \\
\hline $\begin{array}{l}\text { 2. Pressurization of } \\
\text { SGP }\end{array}$ & item 8.2 & $\begin{array}{c}\text { Pressure achieved in } \\
\text { SGP, } 70 \mathrm{mmH}_{2} \mathrm{O} \\
\text { Leakage } \mathrm{L}=4950 \% \text { of } \\
\text { volume per day } \\
\text { (for } \mathrm{P}=0.5 \text { atm gauge); } \\
\text { Leak equivalent } \\
\text { diameter } \mathrm{De}=366 \mathrm{~mm}\end{array}$ & $\begin{array}{l}\text { Pressure achieved in } \\
\text { SGP, } 275 \mathrm{mmH}_{2} \mathrm{O} \\
\text { Leakage } L=768 \% \text { of } \\
\text { volume per day. } \\
\text { (for } \mathrm{P}=0.5 \text { atm gauge); } \\
\text { Leak equivalent } \\
\text { diameter } \mathrm{De}=192 \mathrm{~mm}\end{array}$ & Satisfactory \\
\hline
\end{tabular}

\section{1 . Course of tests}

The testing was conducted in two stages: vacuum testing and pressurization testing.

1.1. Vacuum testing: the SGP [system of pressurized rooms] was prepared for the tests in accordance with the specifications of the testing program. Personnel of the TsNIP [setup, testing and startup department] and repair personnel of the TsTsR [centralized repair shop], TsTAI [thermal automation and measurement department], ETs [electrical shop] and KRU, Kola NPP, were admitted to the pressurized area to look for defects. A vacuum was created in the pressurized enclosure by the operation of two fans of the 2B-4 system (overall flow rate $\mathrm{Q}=80,000 \mathrm{~m}^{3} / \mathrm{h}$ ). The vacuum level was monitored with a $U$-shaped pressure gauge situated on a pulse pressure measurement tube in the steam generator box. 
Several dozen flaws were discovered in the pressure lining, passages and hatch and door seals in the course of the vacuum testing; the flaws basically were eliminated within a day by the repair personnel. Supplementary vacuum testing to confirm the elimination of the defects and possibly to detect new ones was performed before the pressurization testing. At the conclusion of vacuum testing, the pressure valves of ventilation system $2 B-4$ in steam generator box $2 A-4 / 6,7$ were closed, and the vacuum drop time was monitored.

1.2. Pressurization testing: the SGP was prepared for tests in accordance with the specifications of the testing program. A positive pressure was created in the pressurized enclosure by the operation of a compressor to test the pressurized enclosure of the reactor units of phase 2. The pressure was monitored with two pressure gauges with a scale of $0-1 \mathrm{~kg} / \mathrm{cm}^{2}$ and an accuracy class of 0.4 situated on pressure measurement tubes in the steam generator box.

Because of the inadequate capacity of the compressor and the relatively great extent of the pressurization system, the pressure in the sealed enclosure reached $\mathrm{P}=275 \mathrm{mmH}_{2} \mathrm{O}$. An outside inspection of the SGP was performed at this pressure, and the amount of leakage from the GO [pressurized enclosure] was determined after the compressor had been turned off.

2. Conclusions

2.1. The test results are in conformity with the criteria.

2.2. The defects cited in Annex 1 were detected in the course of the tests.

$\begin{array}{ll}\text { [signed] } & \text { S. V. Gorelikhin } \\ \text { [signed] } & \text { T. I. Petkevich } \\ \text { [signed] } & \text { V. V. Sborovskiy }\end{array}$

3. Conclusion

3.1. The integrity of the system of pressurized rooms (SGP) has been enhanced substantially due to the execution of a set of actions during preventive maintenance PPR-96.

3.2. The system of pressurized rooms is hereby cleared for further operation.

3.3. The defects discovered are to be eliminated in accordance with Annex 1. The parties responsible are: the centralized repair shop (TsTsR), the thermal automation and measurement department (TsTAI), the electrical shop (ETs) and the TsEOO (according to affiliation). SGP.

3.4. Measures are to be developed for the further enhancement of the integrity of the

Party responsible: setup, testing and startup department (TsNIP); Deadline: June 1996.
Head of Reactor Department [signed]
P. I. Novozhilov
Head of Setup, Testing
and Startup Department
[signed]
G. S. Paradnikov 
LIST OF DEFECTS OF THE PRESSURIZED ENCLOSURE OF UNIT 2 DISCOVERED DURING TESTS OF THE ENCLOSURE AFTER PREVENTIVE MAINTENANCE PPR-96

\begin{tabular}{|c|c|c|c|}
\hline 1 & 2 & 3 & 4 \\
\hline Item & Room & $\begin{array}{c}\text { Party } \\
\text { responsible for } \\
\text { execution }\end{array}$ & Execution deadline \\
\hline \multicolumn{4}{|l|}{$\begin{array}{l}\text { DISCOVERED DURING VACUUM } \\
\text { TESTING }\end{array}$} \\
\hline $\begin{array}{l}\text { 1. Lining defect (at the top under the } \\
\text { entry door) }\end{array}$ & A-105/2 & & $\begin{array}{l}\text { eliminated after } \\
\text { vacuum testing }\end{array}$ \\
\hline $\begin{array}{l}\text { 2. Lack of fusion penetration in lining in } \\
\text { floor behind RTO }\end{array}$ & A-206/2 & & $\begin{array}{l}\text { eliminated after } \\
\text { vacuum testing }\end{array}$ \\
\hline 3. Leakage under pulse tubes behind RTO & $A-206 / 2$ & & $\begin{array}{l}\text { eliminated after } \\
\text { vacuum testing }\end{array}$ \\
\hline 4. Lining flaw behind platform in wall & A-207/2 & $\begin{array}{c}\text { Centralized } \\
\text { repair shop } \\
\text { (TsTsR) }\end{array}$ & $\begin{array}{l}\text { before startup of } \\
\text { the unit }\end{array}$ \\
\hline $\begin{array}{l}\text { 5. Lining flaw at point of weld of } \\
\text { suspension (left remote) to ceiling }\end{array}$ & $\mathrm{A}-002 / 2$ & & $\begin{array}{l}\text { eliminated after } \\
\text { vacuum testing }\end{array}$ \\
\hline $\begin{array}{l}\text { 6. Lining defect on cable shaft by steam } \\
\text { generator PG-1 }\end{array}$ & $\mathrm{A}-002 / 2$ & & $\begin{array}{l}\text { eliminated after } \\
\text { vacuum testing }\end{array}$ \\
\hline $\begin{array}{l}\text { 7. Lining defect on cable shaft by steam } \\
\text { generator PG- } 6\end{array}$ & A- $-002 / 2$ & & $\begin{array}{l}\text { eliminated after } \\
\text { vacuum testing }\end{array}$ \\
\hline $\begin{array}{l}\text { 8. Lining defect on wall behind steam } \\
\text { generator PG-6 (at inlet of pipeline) }\end{array}$ & A-002/2 & & $\begin{array}{l}\text { eliminated after } \\
\text { vacuum testing }\end{array}$ \\
\hline $\begin{array}{l}\text { 9. Two lining defects on wall behind } \\
\text { steam generator PG-5 }\end{array}$ & A-002/2 & & $\begin{array}{l}\text { eliminated after } \\
\text { vacuum testing }\end{array}$ \\
\hline
\end{tabular}




\begin{tabular}{|c|c|c|c|}
\hline $\begin{array}{l}\text { 10. Lining defect on wall between steam } \\
\text { generator PG-4 and steam generator PG-5 }\end{array}$ & A- $-002 / 2$ & TsTsR & $\begin{array}{c}\text { before startup of } \\
\text { the unit }\end{array}$ \\
\hline $\begin{array}{l}\text { 11. Lining defect of vertical pipeline } \\
\text { passage behind steam generator PG-1 (to } \\
\text { the right of ladder) }\end{array}$ & A-002/2 & TsTsR & $\begin{array}{l}\text { before startup of } \\
\text { the unit }\end{array}$ \\
\hline $\begin{array}{l}\text { 12. Leak on pulse line Dy } 100 \text { (metering) } \\
\text { and along lining separation between } \mathrm{KZV} \\
\text { [exhaust stopper valve] K-11/23 inlet and } \\
\text { lining behind steam generator PG-3 (under } \\
\text { GK service platform) }\end{array}$ & $\mathrm{A}-002 / 2$ & TsTsR & $\begin{array}{l}\text { before startup of } \\
\text { the unit }\end{array}$ \\
\hline 13. Leak on inlet passage Dy 15 & $A-101 / 2$ & & $\begin{array}{l}\text { eliminated after } \\
\text { vacuum testing }\end{array}$ \\
\hline 14. Lining defect on wall at mark 4.5 & A-101/2 & & $\begin{array}{l}\text { eliminated after } \\
\text { vacuum testing }\end{array}$ \\
\hline 15. Lining defect in corner behind channel & $\begin{array}{l}\text { A-101/2 } \\
\text { (top) }\end{array}$ & & $\begin{array}{l}\text { eliminated after } \\
\text { vacuum testing }\end{array}$ \\
\hline $\begin{array}{l}\text { 16. Leak in door seal from } A-101 / 2 \text { to } \\
A-107 / 2\end{array}$ & $A-101 / 2$ & TsTsR & $\begin{array}{l}\text { before startup of } \\
\text { the unint }\end{array}$ \\
\hline 17. Leak on inlet passage Dy20 & $\mathrm{A}-502 / 2$ & & $\begin{array}{l}\text { eliminated after } \\
\text { vacuum testing }\end{array}$ \\
\hline 18. Leak on inlet steam lines & $A-002 / 2$ & TsTsR & $\begin{array}{c}\text { preventive } \\
\text { maintenance PPR- } \\
97\end{array}$ \\
\hline $\begin{array}{l}\text { 19. Defect or main circulating pump } \\
\text { (GTsK) support (cold line) of loop } 1\end{array}$ & $\mathrm{~A}-002 / 2$ & & $\begin{array}{l}\text { eliminated after } \\
\text { vacuum testing }\end{array}$ \\
\hline $\begin{array}{l}\text { 20. Leak along pipeline Dy200 (at floor) } \\
\text { by } 2 \mathrm{P}-2 / 6\end{array}$ & $\begin{array}{l}\text { A-102/2 } \\
\text { (inner } \\
\text { wall) }\end{array}$ & & $\begin{array}{l}\text { eliminated after } \\
\text { vacuum testing }\end{array}$ \\
\hline 21. Leak on cable passage & $A-103 / 2$ & & $\begin{array}{l}\text { eliminated after } \\
\text { vacuum testing }\end{array}$ \\
\hline $\begin{array}{l}\text { 22. Leaks in seal of operation hatch and } \\
\text { hatch above } 2 \text { GTsN-4 }\end{array}$ & & & $\begin{array}{c}\text { preventive } \\
\text { maintenance PPR- } \\
97\end{array}$ \\
\hline $\begin{array}{l}\text { 23. Leak in floor (bordering on room A- } \\
004 / 3 \text { ) }\end{array}$ & $\mathrm{A}=002 / 2$ & & $\begin{array}{l}\text { eliminated after } \\
\text { vacuum testing }\end{array}$ \\
\hline
\end{tabular}




\begin{tabular}{|c|c|c|c|}
\hline $\begin{array}{l}\text { 24. Gas pocket under connecting platform } \\
\text { in room } \mathrm{A}-013 / 2\end{array}$ & A- $-002 / 2$ & & $\begin{array}{l}\text { eliminated after } \\
\text { vacuum testing }\end{array}$ \\
\hline $\begin{array}{l}\text { 25. Gas pocket in weld at joining of floor } \\
\text { and wall of room A-013/2 (to right of } \\
\text { entrance) }\end{array}$ & $\mathrm{A}-002 / 2$ & & $\begin{array}{l}\text { eliminated after } \\
\text { vacuum testing }\end{array}$ \\
\hline $\begin{array}{l}\text { 26. Defect by passage in wall in room A- } \\
012 / 2 \text { at floor level }\end{array}$ & A-002/2 & & $\begin{array}{l}\text { eliminated after } \\
\text { vacuum testing }\end{array}$ \\
\hline $\begin{array}{l}\text { 27. Weld defect on support of pipeline } \\
\text { Dy } 500 \text { of cold line, loop } 1\end{array}$ & $\mathrm{~A}-002 / 2$ & & $\begin{array}{l}\text { eliminated after } \\
\text { vacuum testing }\end{array}$ \\
\hline $\begin{array}{l}\text { 28. Weld defect on face of support prop } \\
\text { under } 2 \mathrm{PG}-6\end{array}$ & $A-002 / 2$ & & $\begin{array}{l}\text { eliminated after } \\
\text { vacuum testing }\end{array}$ \\
\hline 29. Gas pocket on wall of cable shaft & $\mathrm{A}-002 / 2$ & & $\begin{array}{l}\text { eliminated after } \\
\text { vacuum testing }\end{array}$ \\
\hline $\begin{array}{l}\text { 30. Ceiling lining defect next to KZV K- } \\
11 / 24 \text { and } \mathrm{K}-11 / 25\end{array}$ & A- $-002 / 2$ & TsTsR & $\begin{array}{l}\text { before startup of } \\
\text { the unit }\end{array}$ \\
\hline $\begin{array}{l}\text { 31. Lining defect by gangway ( } 1.5 \mathrm{~m} \text { from } \\
\text { floor) }\end{array}$ & $A-013 / 2$ & & $\begin{array}{l}\text { eliminated after } \\
\text { vacuum testing }\end{array}$ \\
\hline $\begin{array}{l}\text { 32. Weld defect on frame of opening } \\
\text { between room A-013/2 and SVO-1 }\end{array}$ & $A-013 / 2$ & & $\begin{array}{l}\text { eliminated after } \\
\text { vacuum testing }\end{array}$ \\
\hline 33. Weld defect in lining of gangway & Â-013/2 & & $\begin{array}{l}\text { before startup of } \\
\text { the unit }\end{array}$ \\
\hline 34. Leak on pulse tube inlet & $\mathrm{A}-001 / 2$ & & $\begin{array}{l}\text { eliminated after } \\
\text { vacuum testing }\end{array}$ \\
\hline $\begin{array}{l}\text { 35. Leaks on hatches Dy800 of system R- } \\
1-2,3,4,5\end{array}$ & $\mathrm{~B}-009 / 2$ & TsEOO & $\begin{array}{c}\text { before startup of } \\
\text { the unit }\end{array}$ \\
\hline $\begin{array}{l}\text { 36. Weld defect around pulse tube above } \\
\text { KIP box (SIR-324) opposite } 2 \mathrm{P}-2 / 6\end{array}$ & $A-102 / 2$ & & $\begin{array}{l}\text { eliminated after } \\
\text { vacuum testing }\end{array}$ \\
\hline 37. Weld defect around $2 \mathrm{P}-1 / 4,2 / 2,1 / 2$ & A- $102 / 2$ & TsTsR & $\begin{array}{l}\text { before startup of } \\
\text { the unit }\end{array}$ \\
\hline $\begin{array}{l}\text { 38. Lining burn-through at point of weld } \\
\text { of hoist beam between loops } 2 \text { and } 3\end{array}$ & $A-102 / 2$ & & $\begin{array}{l}\text { eliminated after } \\
\text { vacuum testing }\end{array}$ \\
\hline
\end{tabular}




\begin{tabular}{|l|c|c|c|}
\hline $\begin{array}{l}\text { 39. Defect on abutment of } \mathrm{KD} \text { [pressure } \\
\text { relief valve] inlet with pressure lining (2.5 } \\
\text { right of door, last on left) }\end{array}$ & $\begin{array}{c}\text { circular } \\
\text { corridor } \\
211-4\end{array}$ & TsTsR & $\begin{array}{c}\text { eliminated after } \\
\text { vacuum testing }\end{array}$ \\
\hline $\begin{array}{l}\text { 40. Leak on section under reactor cover } \\
\text { of transportation passage from BV [spent } \\
\text { fuel pool] to BP }\end{array}$ & $\begin{array}{c}\text { preventive } \\
\text { maintenance PPR- } \\
97\end{array}$ \\
\hline $\begin{array}{l}\text { 41. In room A-015/5, cut and seal pipe } \\
\text { Dy32 (in room A-002/2, the pipe passes } \\
\text { around the ring of the reactor shaft at a } \\
\text { height of } 1.5 \mathrm{~m} \text { from the floor) }\end{array}$ & & TsTsR & $\begin{array}{c}\text { preventive } \\
\text { maintenance PPR- } \\
97\end{array}$ \\
\hline $\begin{array}{l}\text { 42. Numerous lining defects in reactor } \\
\text { shaft under cantilever }\end{array}$ & TsTsR & $\begin{array}{c}\text { preventive } \\
\text { maintenance PPR- } \\
97\end{array}$ \\
\hline
\end{tabular}




\begin{tabular}{|l|c|c|c|}
\hline \multicolumn{1}{|c|}{1} & 2 & 3 & 4 \\
\hline $\begin{array}{l}\text { DISCOVERED IN PRESSURIZATION } \\
\text { TESTING }\end{array}$ & & & \\
\hline 1. Leak on gangway lining & A-303/2 & TsTsR & $\begin{array}{c}\text { before startup of } \\
\text { the unit }\end{array}$ \\
\hline $\begin{array}{l}\text { 2. Leak on pulse passage (left of door to } \\
\text { room A-308/2) }\end{array}$ & A-306/2 & $\begin{array}{c}\text { thermal } \\
\text { automation } \\
\text { and } \\
\text { measurement } \\
\text { department } \\
\text { (TsTAI) }\end{array}$ & $\begin{array}{c}\text { before startup of } \\
\text { the unit }\end{array}$ \\
\hline $\begin{array}{l}\text { 3. Leak on 2PG-3 constant ventilation } \\
\text { passage }\end{array}$ & A-014/2 & TsTsR & $\begin{array}{c}\text { before startup of } \\
\text { the unit }\end{array}$ \\
\hline $\begin{array}{l}\text { 4. Leak on KIP passage by 2PG-4,5 } \\
\text { constant ventilation passage }\end{array}$ & A-014/2 & TsTsR & $\begin{array}{c}\text { before startup of } \\
\text { the unit }\end{array}$ \\
\hline 5. Leak in gangway weld & B-007/2 & TsTsR & $\begin{array}{c}\text { preventive } \\
\text { maintenance } \\
\text { PPR-97 }\end{array}$ \\
\hline $\begin{array}{l}\text { 6. Leak around circumference of air iniet } \\
\text { passage (in right wall) }\end{array}$ & $\begin{array}{l}\text { B-210/2 } \\
\text { (second } \\
\text { room) }\end{array}$ & TsTsR & $\begin{array}{c}\text { preventive } \\
\text { maintenance } \\
\text { PPR-97 }\end{array}$ \\
\hline $\begin{array}{l}\text { 7. Leak in Dy800 hatch seal (4 from } \\
\text { entrance) }\end{array}$ & B-008/2 & TsEOO & $\begin{array}{c}\text { before startup of } \\
\text { the unit }\end{array}$ \\
\hline $\begin{array}{l}\text { 8. Leak in rectangular hatch seal (2 and } 4 \\
\text { from entiance) }\end{array}$ & B-008/2 & TsEOO & $\begin{array}{c}\text { before startup of } \\
\text { the unit }\end{array}$ \\
\hline $\begin{array}{l}\text { 9. Leaks in gland seal of ventilator shafts } \\
\text { 2R-1-3,4,5 } \\
\text { protective plates of ventilator system 2P-1 }\end{array}$ & B-005/2 & TsEOO & $\begin{array}{c}\text { preventive } \\
\text { maintenance } \\
\text { ppR-97 (assemble } \\
\text { face seals) }\end{array}$ \\
\hline $\begin{array}{l}\text { preventive } \\
\text { maintenance } \\
\text { PPR-97 }\end{array}$ \\
\hline
\end{tabular}




\begin{tabular}{|l|c|c|c|}
\hline $\begin{array}{l}\text { 11. KIP control valve (backup line P) out } \\
\text { of order at gate valve 21-17/4 }\end{array}$ & B-005/2 & TsTAI & $\begin{array}{c}\text { preventive } \\
\text { maintenance } \\
\text { PPR-97 }\end{array}$ \\
\hline $\begin{array}{l}\text { 12. Leaks in two cable passages (45-46, } \\
\text { for example) }\end{array}$ & A-203/2 & TsTAI & $\begin{array}{c}\text { before startup of } \\
\text { the unit }\end{array}$ \\
\hline $\begin{array}{l}\text { 12. Leak in cable passage (47, for } \\
\text { example) }\end{array}$ & A-008/2 & TsTAI & $\begin{array}{c}\text { before startup of } \\
\text { the unit }\end{array}$ \\
\hline $\begin{array}{l}\text { 13. Leak in cable passage (48, for } \\
\text { example) }\end{array}$ & A-008/2 & TsTAI & $\begin{array}{c}\text { before startup of } \\
\text { the unit }\end{array}$ \\
\hline 14. Leak in KIP inlet passage & A-012/2 & TsTsR & $\begin{array}{c}\text { before startup of } \\
\text { the unit }\end{array}$ \\
\hline 15. Leak in gangway lining & A-303/2 & TsTsR & $\begin{array}{c}\text { before startup of } \\
\text { the unit }\end{array}$ \\
\hline
\end{tabular}




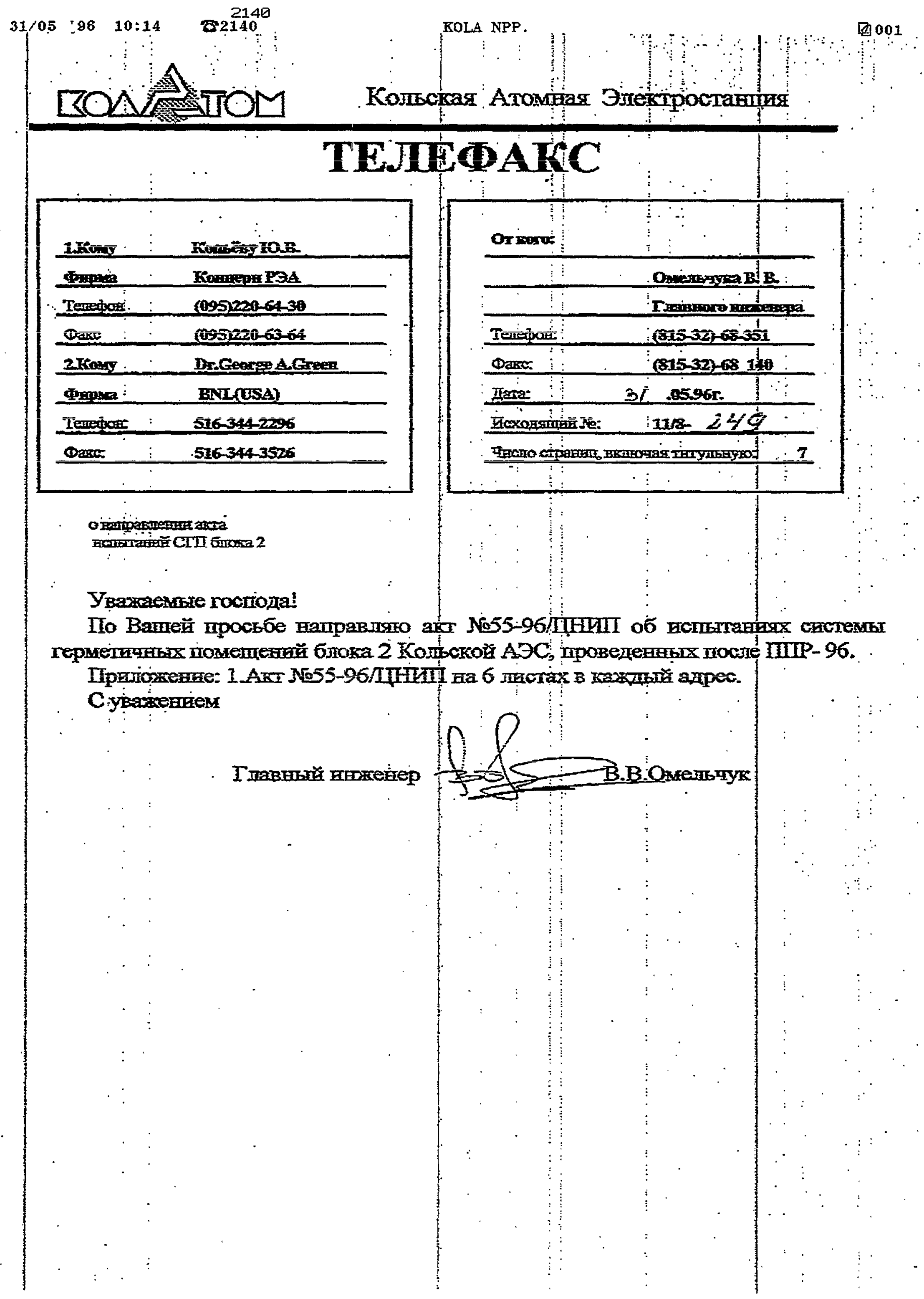



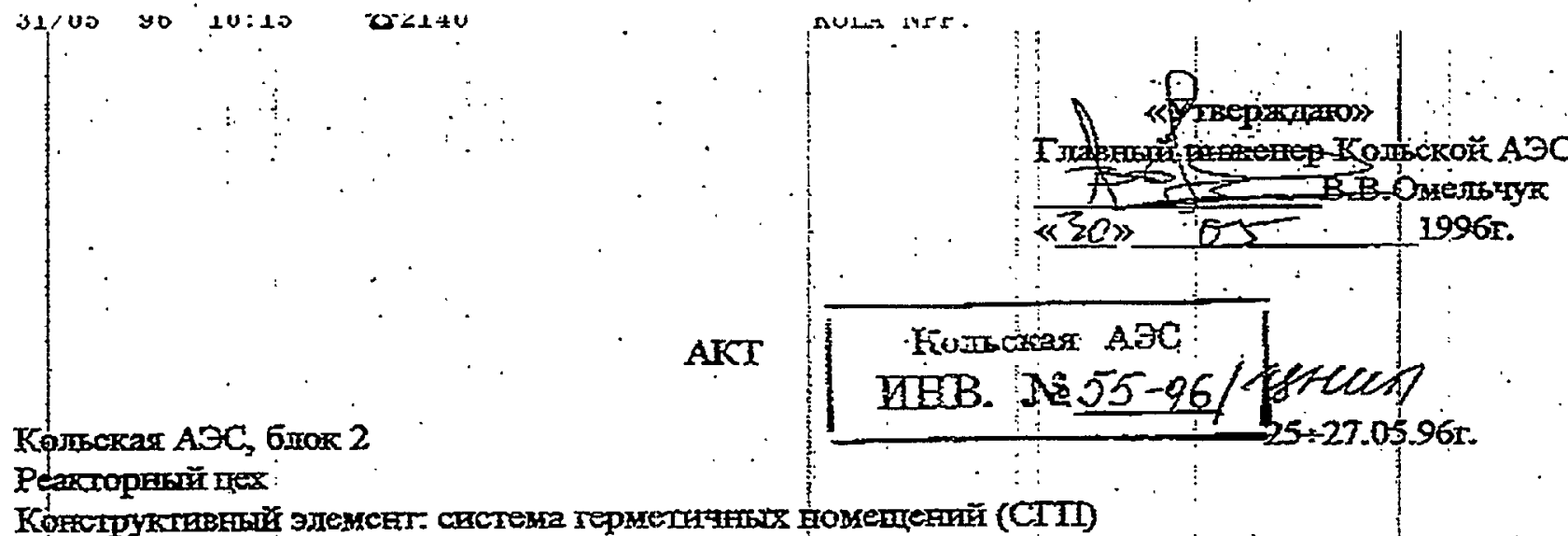

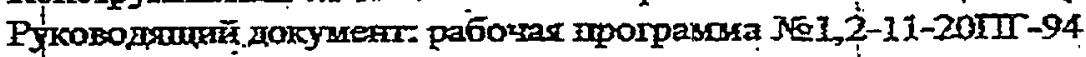

Kourzceras в coctabe:

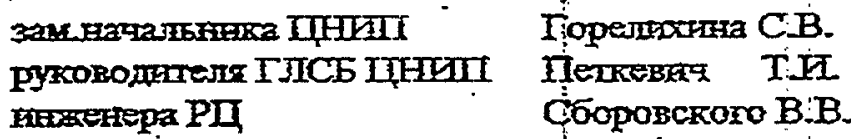

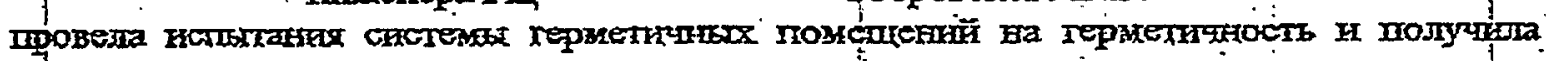

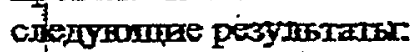

\begin{tabular}{|c|c|c|c|c|}
\hline 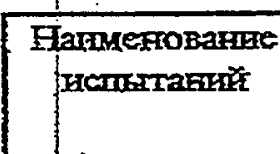 & 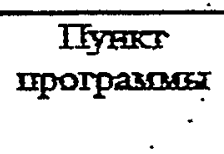 & 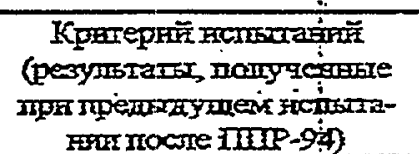 & 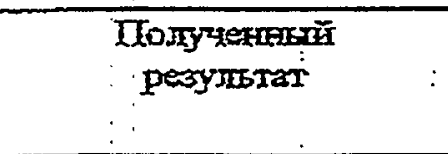 & 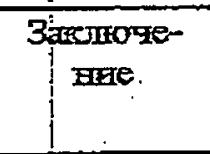 \\
\hline $\begin{array}{l}\text { I BakyyMmpora } \\
\text { zxte ClII }\end{array}$ & II 8.1 & $\begin{array}{l}\text { Paspexerne в CTI } \\
190 \text { son } \text { в.cr. }\end{array}$ & $\begin{array}{c}\text { Paspexenzte в CIII } \\
226 \text { M в.ст. }\end{array}$ & 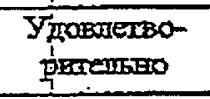 \\
\hline 2Н & II.8.2. & 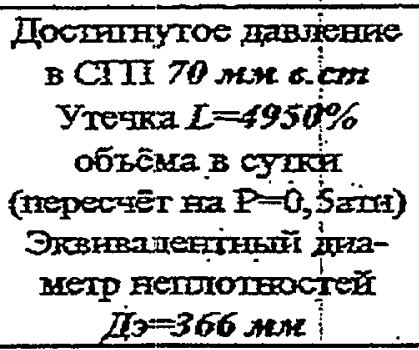 & 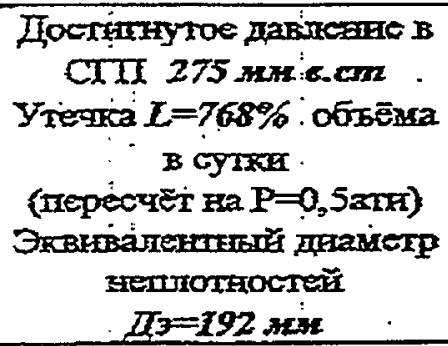 & 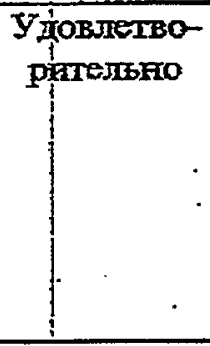 \\
\hline
\end{tabular}

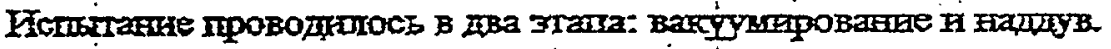

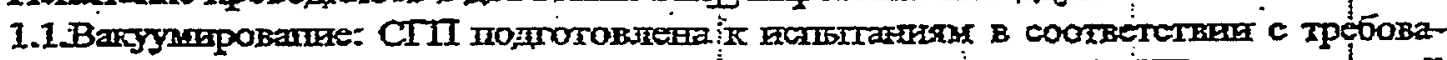

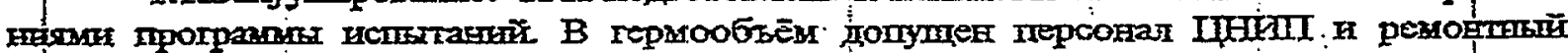

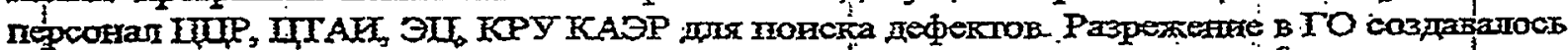

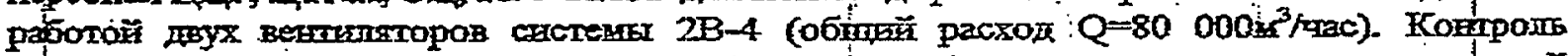

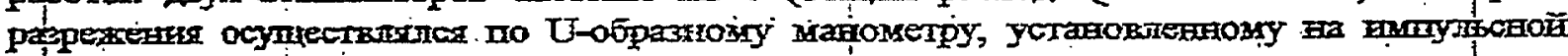

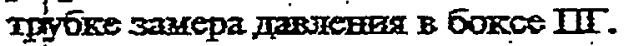

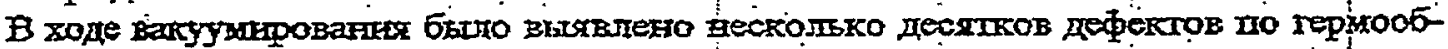

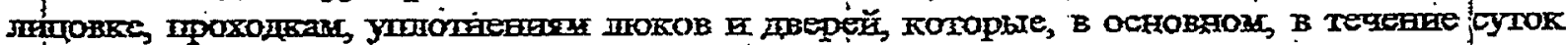

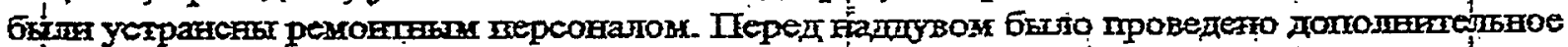

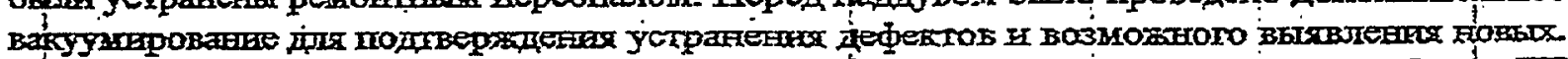

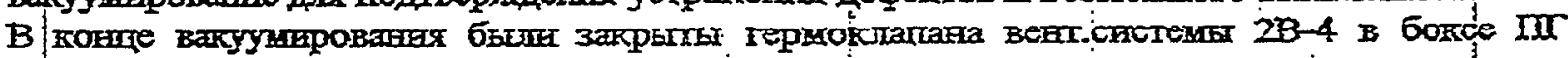

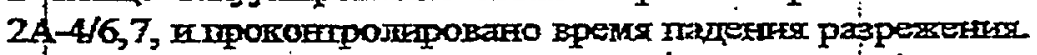

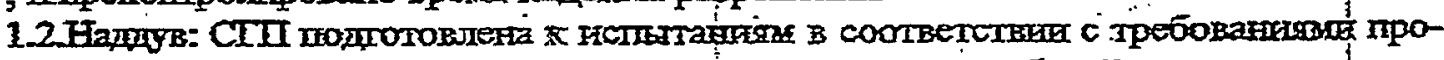

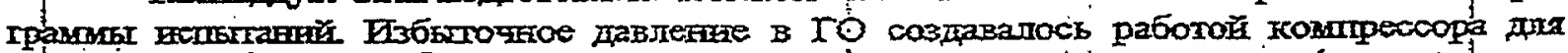

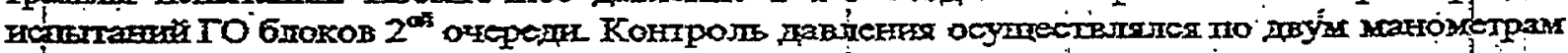
co

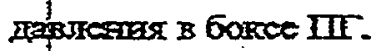




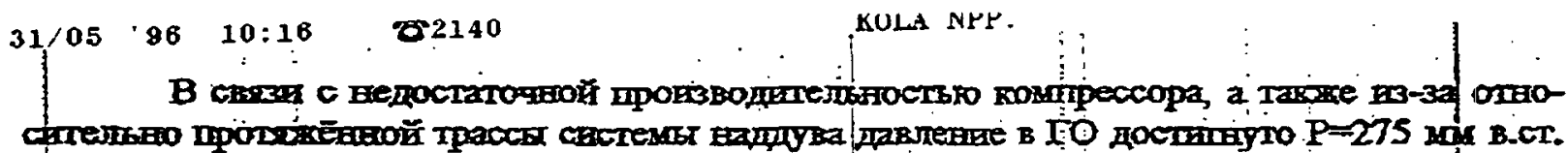

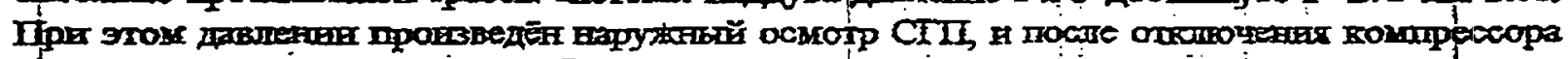

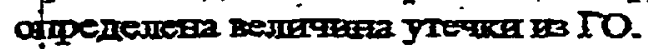

2Bropoprix

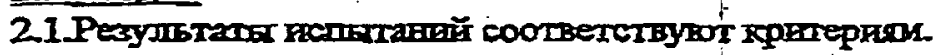

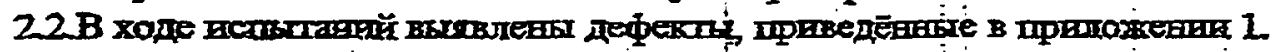

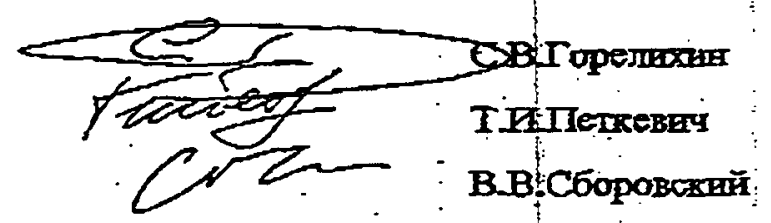

3.3arrotere

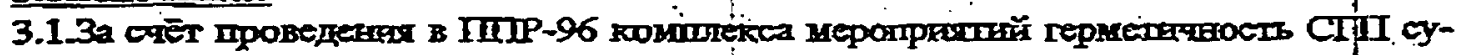
IIforzeario yBenzutures.

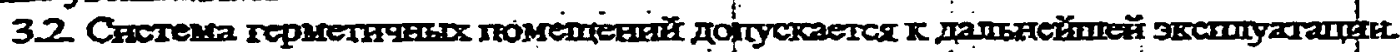

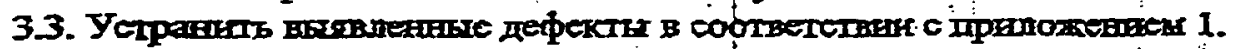

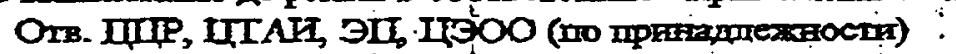

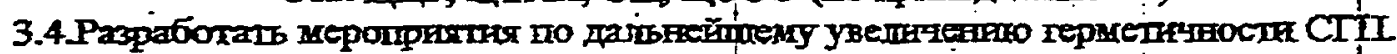
Om ITHसा

Haquibark PII

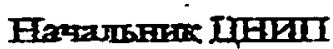

Toperomom, $23-64$

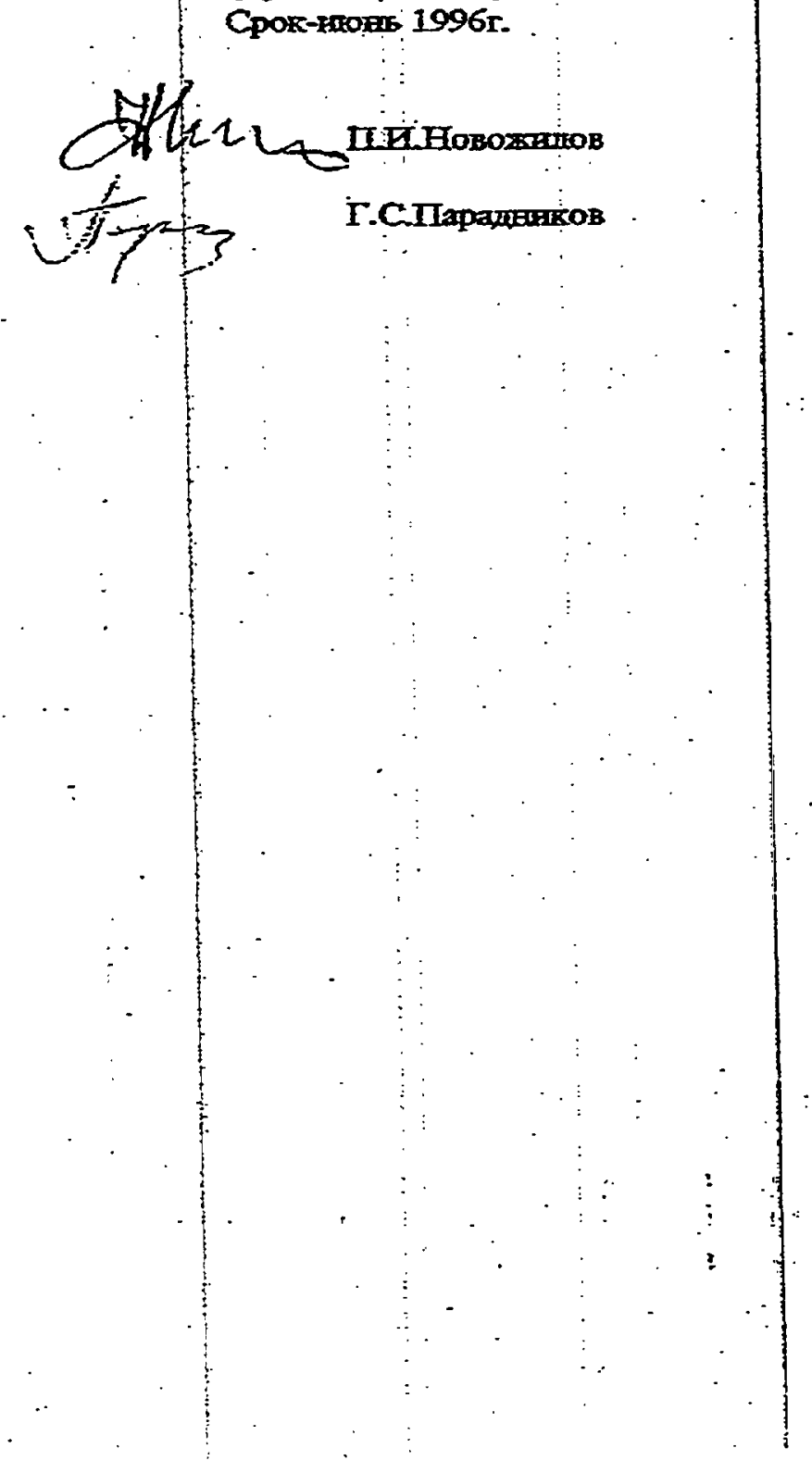




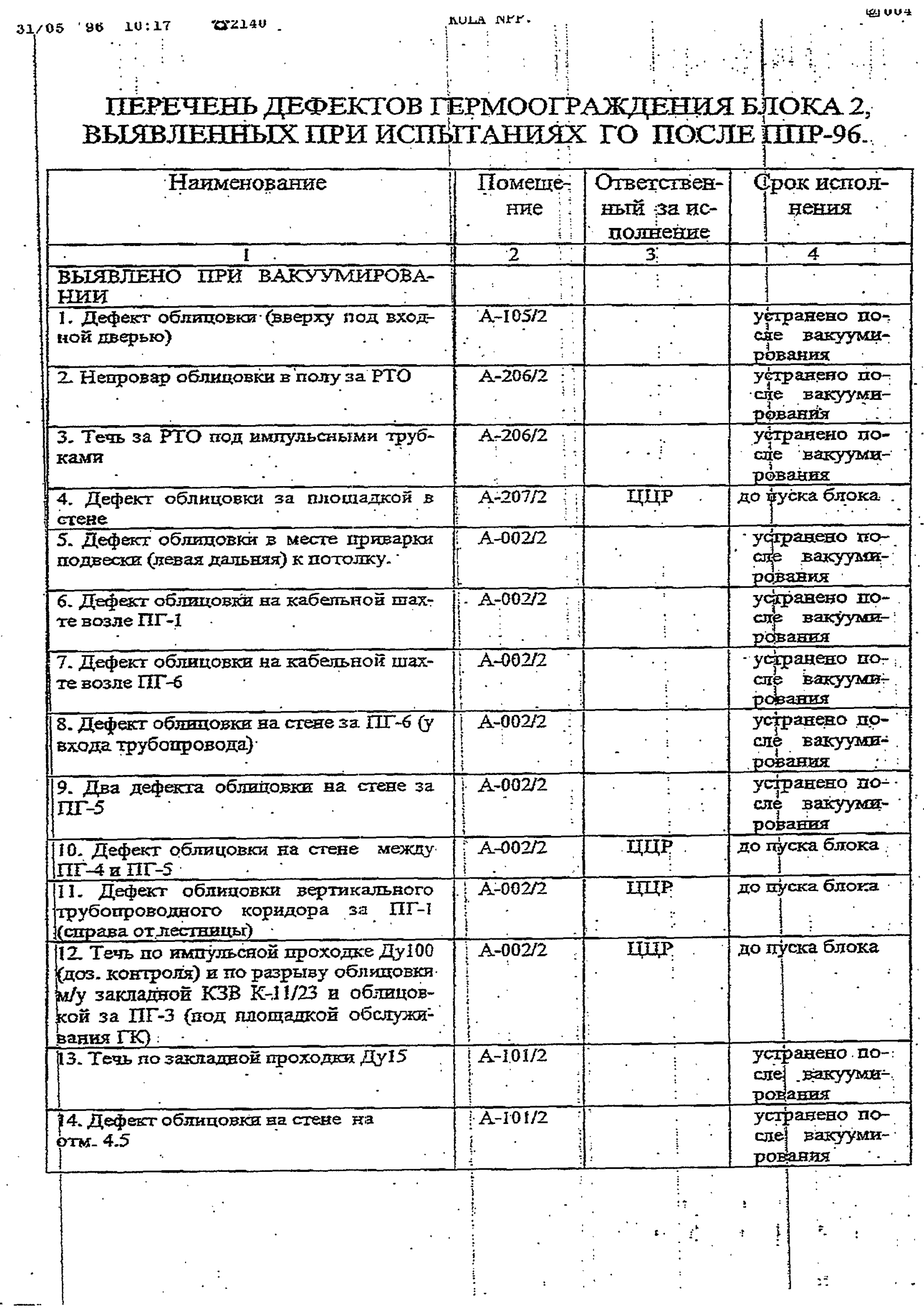




\begin{tabular}{|c|c|c|c|}
\hline 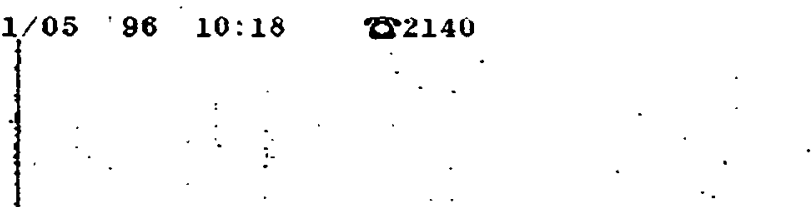 & KULA NYY. & & $\cdots$ \\
\hline 1 & 2 & $\overline{3}$ & 4 \\
\hline $\begin{array}{l}\text { 15. Дефект облшдовка в углу за шввелге- } \\
\text { ром }\end{array}$ & $\begin{array}{l}A-101 / 2 \\
(\text { (веp } x)\end{array}$ & & 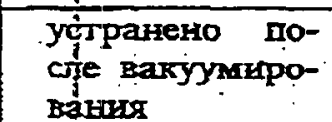 \\
\hline $\begin{array}{l}\text { I6. Течь до ушшотненпго двери из } \\
\text { А-101/2 в А-107/2 }\end{array}$ & $A-101 / 2$ & цL(ए) & до пiуска блока \\
\hline 17. Течь по закпалвой прохопки Ду20 & $A-502 / 2$ & & $\begin{array}{l}\text { yétipafero по- } \\
\text { çe: вakyуми- } \\
\text { pósanrs. }\end{array}$ \\
\hline 18. Тети по закладным паропроводов & $A-002 / 2$ & ЦцP & ПIIP-97 \\
\hline $\begin{array}{l}\text { 19. Дефект на опоре ГЦК (холодная } \\
\text { нитка) петлI I }\end{array}$ & $A-002 / 2$ & & $\begin{array}{l}\text { yéppakerio ño- } \\
\text { cpe вakyyịn- } \\
\text { posarna }\end{array}$ \\
\hline $\begin{array}{l}\text { 20. Течь вдопь трубопровода Ду200 (у } \\
\text { пола) возле } 2 \mathrm{P}-2 / 6\end{array}$ & $\begin{array}{l}\text { A-102/2 } \\
\text { (внутр. } \\
\text { стева) }\end{array}$ & ¿ & $\begin{array}{l}\text { усіравево по- } \\
\text { сре вакуума- } \\
\text { ровавия }\end{array}$ \\
\hline 21. Течь по кабепьной проходке & $A-103 / 2$ & $\begin{array}{c}\vdots \\
\vdots\end{array}$ & 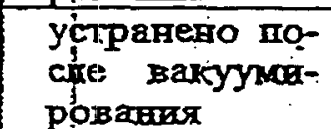 \\
\hline 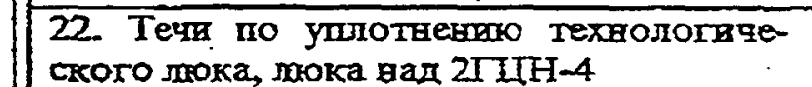 & & & आयम \\
\hline $\begin{array}{l}\text { 23. Тетв в полу (пршаныкание к пом. A- } \\
004 / 3 \text { ). }\end{array}$ & $A-002 / 2$ & $\vdots$ & 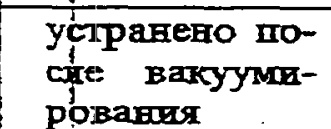 \\
\hline $\begin{array}{l}\text { 24. Свнші под переходной плочадкой в } \\
\text { пом. А-013/2 }\end{array}$ & $\mathrm{A}-002 / 2$ & & 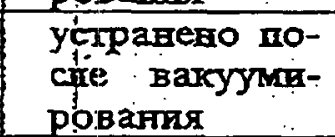 \\
\hline $\begin{array}{l}\text { 25. Свиц в сварном шве примькағіпя } \\
\text { пола к стене пом. А-013/2 (страва от } \\
\text { входа) }\end{array}$ & $A-002 / 2$ & $\vdots$ & 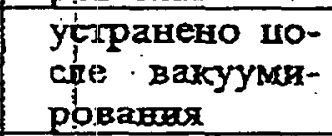 \\
\hline $\begin{array}{l}\text { 26. Дефект возле прохопки в стеке в } \\
\text { пом. А-012Д ва уровнепола. } \\
\text { : }\end{array}$ & $A-002 / 2$ & & 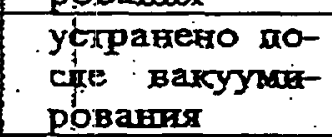 \\
\hline $\begin{array}{l}\text { 27. Дефект сварвого цива на опоре тру- } \\
\text { бопровода Ду } 500 \text { хол. нитки пети Ао } 1 \text {. }\end{array}$ & $A-002 / 2$ & : & 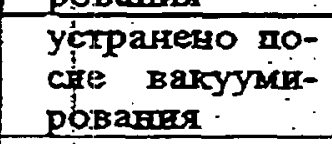 \\
\hline $\begin{array}{l}\text { 28. Дефект сварного пшва ва торде под- } \\
\text { коса опоры под } 2 \Pi Г-6 .\end{array}$ & $A-002 / 2$ & : & 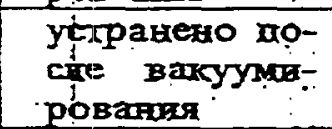 \\
\hline 28. Свищ на стене кабетьной шахты. & $A-002 \sqrt{2}$. & $\vdots$ & 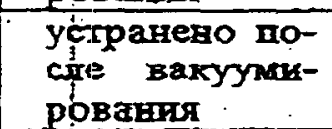 \\
\hline $\begin{array}{l}\text { 30. Дефект облидовка потолка рядом с } \\
\text { К } 3 \text { В К-11/24, K-1//25. }\end{array}$ & $A-002 / 2$ & цUР & до. ïycka блоқа. \\
\hline $\begin{array}{l}\text { 31. Дефект обпицовки возле трапа }(1,5 \mathrm{M} \\
\text { от пола). }\end{array}$ & $A-013 / 2$ & & $\begin{array}{l}\text { устранево по- } \\
\text { ске вакууми- } \\
\text { posanis }\end{array}$ \\
\hline $\begin{array}{l}32 \text { Дефект сварного іпва по обрампе } \\
\text { нию проема межсду пом. А-013/2 и } \\
\text { СВО-1 }\end{array}$ & $A-013 / 2$ & & 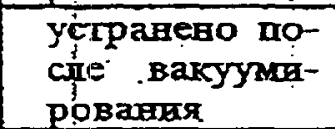 \\
\hline $\begin{array}{l}\text { 33. Дефект сварвого пиа в обпииовке } \\
\text { трапа }\end{array}$ & $A-013 / 2$ & & до Пууска блока \\
\hline : & & $\begin{array}{ll}\therefore \\
\therefore\end{array}$ & $\begin{array}{lll} & & \\
\therefore & & \\
\therefore & & \\
\therefore & & \end{array}$ \\
\hline
\end{tabular}




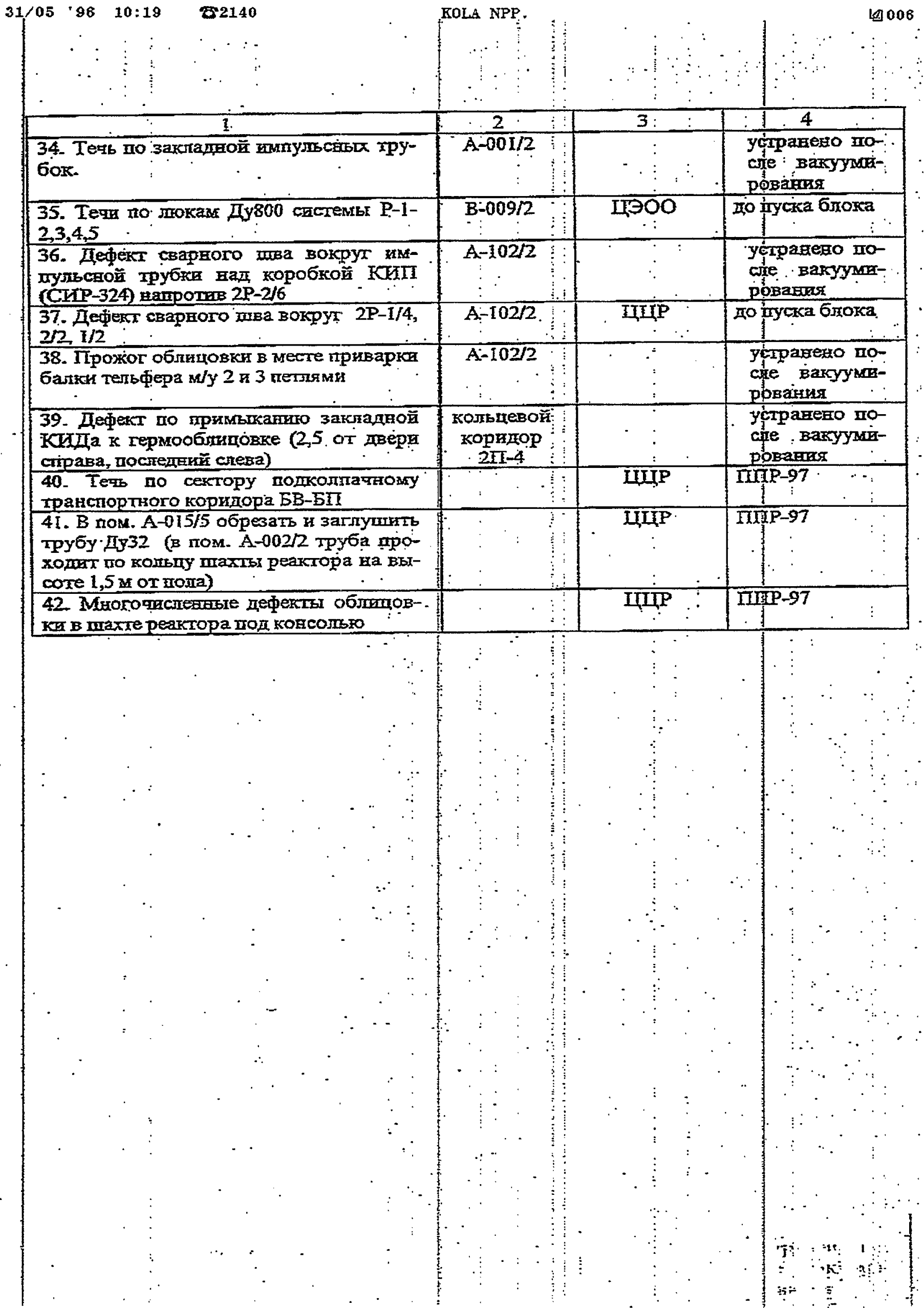




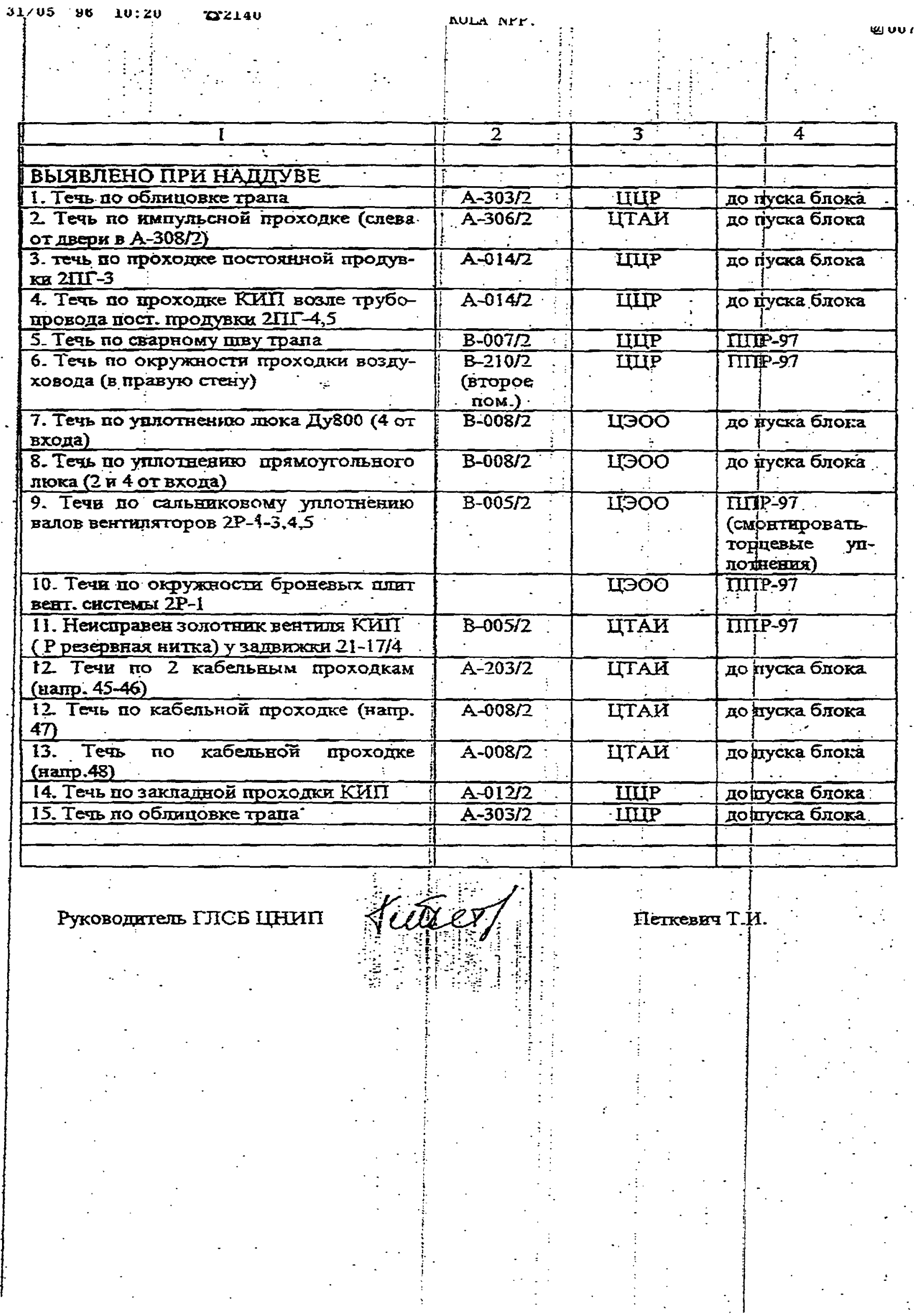




\section{ATTACHMENT 6 \\ Results of Leaktightness Testing for Kola Unit 1 (10/96) \\ (English and Russian)}


KOLA-ATOM Kola Nuclear Power Plant

TELEFAX

\begin{tabular}{|l|l|}
\hline To: Dr. George Greene & From: Omel'chuk, V.V. \\
\hline Company: BNL (USA) & \multicolumn{1}{|c|}{ Chief Engineer } \\
\hline & Telephone: 815-32-68-351 \\
\hline & Fax: $815-32-68-140$ \\
\hline Telephone: 516-344-2296 & Date: Dec. 15, 1996 \\
\hline Fax: 516-344-3526 & $\begin{array}{l}\text { Issuing No. 11/8-519 } \\
\text { Number of pages, including cover page: } 8\end{array}$ \\
\hline
\end{tabular}

Dear Mr. Green!

I am directing to your attention documentation regarding integral leak-tight testing of the containment (hermetic sheild) for Unit 1 following the planned outage of the unit. The completed maintenance work and the repair/reconstruction of the elements of the hermetic barrier system have contributed to a considerable decrease in the amount of leakage from the containment. However, as always, large leakage of air during the testing was observed through the ventilation system of the hermetic bartier system.

During the sealing of the hatches following their construction/repair, it was determined, that in order to substantially seal them it was imperative to use a softer rubber, than the one that was provided by you earlier at the Kola NPP of the size $15 \times 20 \mathrm{~mm}$ ( instead of $15 \times 30$ ). I am asking that you look nto the possibility of supplying this type of rubber for the Kola NPP. The required amount of rubber is indicated in the Kola NPP fax "Issue number 11/8-448" dated October 16, 1996.

In the weekly progress report from October 25,1996 , according to the International program for Nuclear Safety, prepared by PNL (USA, Richland, Washington Stated), it is indicated that Argonne National Laboratory (ANL) personnel have prepared for the Hungarian NPP a report "Containment Loading and Structural Response during Accidents Involving Rupture of Widediameter Steam Pipes at VVER-440/213 NPP"(Jeff Binder, ANL, 630--252-7265). I am asking for your help in providing/directing a copy of this document to the Kola NPP in order to study this document and it's possible application/utilization.

Attachment: Document No.182-96/CNIP from December 04, 1996 regarding integral leaktight testing of hermetic seal/containment of Unit 1 following pianned outage on 7 pages in one submittal.

With Respect, Chief Engineer

Omel'chuk V.V. 
Chief Engineer Kola NPP V.V. Omel'chuk

Dec. 12

1996

NPP

182-96/CNIP

Document

Kola NPP, Unit 1

Reactor (Unit )?

Structural Element: System of Hermetic Units/Compartments

Guidance Document:Working Program No.1,2-11-20PG-94

Committe Members:
Acting Director CNIP
Gorelichina, S.V.
Manager GLSB CNIP
Petkovich, T.I.
Engineer RC
Sborovskoi V.V.

Conducted testing of leak-tightness of the hermetic enclosures/spaces and obtained the following results:

\begin{tabular}{|l|l|l|l|l|}
\hline $\begin{array}{l}\text { Name/type of } \\
\text { experiment }\end{array}$ & Program item & $\begin{array}{l}\text { Criteria for } \\
\text { experiments } \\
\text { (results,obtained } \\
\text { from previous } \\
\text { experiments } \\
\text { during Planned } \\
\text { Outage- 1995) }\end{array}$ & Results Obtained & Conclusions \\
\hline $\begin{array}{l}\text { 1. "Vacuuming / } \\
\text { evacuation of } \\
\text { Central Hermetic } \\
\text { system }\end{array}$ & $p .8 .1$ & $\begin{array}{l}\text { Exhaust into the } \\
\text { Central Hermetic } \\
\text { System 100 } \\
\text { mm/24 hrs }\end{array}$ & $\begin{array}{l}\text { Exhaust into } \\
\text { CHm/224hrs } \\
\text { mm }\end{array}$ & Satisfactory \\
\hline of CHS & $p .8 .2$ & $\begin{array}{l}\text { Attained pressure } \\
\text { level in CHS } \\
90 \text { mm/24hrs }, \\
\text { leakage } \\
\text { L=4560\% } \\
\text { volume in 24 hrs } \\
\text { (recalculation to } \\
\text { P=0,5 atm. } \\
\text { Equivalent } \\
\text { diameter of } \\
\text { openings } \\
\mathrm{D=354mm}\end{array}$ & $\begin{array}{l}\text { Attained pressure } \\
\text { in CHS 320 } \\
\text { mm,/24hrs } \\
\text { Leakage L=720\% } \\
\text { volume in 24 hrs. } \\
\text { (recalculation for } \\
\text { P=0,5atm. } \\
\text { Equivalent } \\
\text { diameter of } \\
\text { openings D=134 } \\
\text { (184?) mm }\end{array}$ & Satisfactory \\
\hline
\end{tabular}




\section{Experimental Steps.}

The experiments were conducted in two stages: vacuuming and pressurization

1.1 Vacuuming: CHS (Central Hermetic System) was prepared for the experiments in accordance with the testing requirements. CNIP personnel were permitted into primary containment along with --,--, --,- KNPP personnel in order to locate defects. Exhaust into the primary containment/hermetic seal was accomplished with two fans in the $2 \mathrm{~V}-4$ system (general rate $Q=80$ $000 \mathrm{~m} 3 / \mathrm{hr}$.). The control of the exhaust was accomplished by U-like pressure gage, located on the impulse pipe pressure indicator in box PG(power generator).

During the vacuuming process more than twenty defects were determined along the outerskin of the containment/hermetic covering, along penetrations, along hatch and door seals, the most significant of which were eliminated by maintenance crews during two shifts.

1.2 Pressurization: CHS was prepared for exeriments in accordance with testing prgram requirements. Surplus (excess) pressure in the containment/hermetic cover was created by a compressor for testing the leak-tightness of the units as the following measure. The pressure control was maintained by two gauges with a scale $0+1--/ \mathrm{cm} 2$ degree of accuracy 0.4 , located on the impulse pipe pressure indicator in box/unit PG.

In connection with the inadequate functioning of the compressor, and like-wize because of the considerable line of route of the exhaust system, pressure in the primary containment/hermetic seal reached $\mathrm{p}=320 \mathrm{~mm}$ in $24 \mathrm{hrs}$.

P.3.

At this pressure level an external inspection was conducted of the CHS (containment/hermetic system), after turning off the compressor the rate of leakage from the containment was determined.

2. Conclusions.

2.1. Results of the tests were in accordance with the criteria.

2.2. The defects discovered during the testing, were eliminated. 1.

\section{S.V. Gorelikhin \\ T.I. Petkevich \\ V.V. Sborovskii}

\section{In Summary.}

3.1.By taking advantage of the Planned Outage- 96 at the complex, considerable improvements to the CHS were achieved.

3.2 The system of hermetic spaces/units can now permit future power operations.

3.3. Eliminate the revealed defects in accordance with the attachment.

"Responsible parties" ---,---,-,-,-, (according to affiliations)

3.4. Develop improvements for improving the leak-tightness of the CHS during the Planned Outage -97 .

Director of RC

Director of CNIP
"Responsibility of CNIP

P.I.Novojilov

G.S.Paradnikov
During December 1996 
p. 4

LIST OF DEFECTS IN THE HERMETIC CONTAINMENT, REVEALED DURING TESTING IN 1996.

\begin{tabular}{|c|c|c|c|c|c|}
\hline No. & Name/Item & No. No. & $\begin{array}{l}\text { Responsibil. } \\
\text { for } \\
\text { elimination }\end{array}$ & $\begin{array}{l}\text { Period/time of } \\
\text { elimination }\end{array}$ & Comments \\
\hline \multicolumn{6}{|c|}{ REVEALED DURING VACUUMING } \\
\hline 1. & $\begin{array}{l}\text { Leakage of air along gasket } \mathrm{K} \text { - } \\
11 / 1\end{array}$ & A-105/1 & CEOPO & $\begin{array}{l}\text { before } \\
\text { pressurization }\end{array}$ & eliminated \\
\hline 2. & $\begin{array}{l}\text { Leakage of air along gasket } \mathrm{K} \text { - } \\
12 / 14\end{array}$ & A-109/1 & CEOO & $\begin{array}{l}\text { before } \\
\text { pressurization }\end{array}$ & eliminated \\
\hline 3. & $\begin{array}{l}\text { Improperly positioned terminator } \\
\mathrm{K}-11 / 18\end{array}$ & A-108/1 & CTAI & $\begin{array}{l}\text { before } \\
\text { pressurization }\end{array}$ & eliminated \\
\hline 4. & $\begin{array}{l}\text { Re-seal door-hatch of air passage } \\
1 V-1 \text { in front of hermetic valve } \\
1 G-1\end{array}$ & $V-304$ & CEOO & $\begin{array}{l}\text { Planned } \\
\text { outage-97 }\end{array}$ & \\
\hline 5. & $\begin{array}{l}\text { Leakage of air along welded seam } \\
\text { between foundation and piping } \\
\text { conduits for service water }\end{array}$ & $16-005$ & KAER & $\begin{array}{l}\text { December } \\
1996\end{array}$ & $\begin{array}{l}\text { seal with } \\
\text { air-tight } \\
\text { packing }\end{array}$ \\
\hline 6. & $\begin{array}{l}\text { Defect of the outer shell of the } \\
\text { maintenance area PK KO, } \\
\text { "otm"10.5 (behind 1R-17/4) }\end{array}$ & $A-101 / 1$ & KAER & $\begin{array}{l}\text { before power } \\
\text { start-up of the } \\
\text { Unit }\end{array}$ & eliminated \\
\hline 7. & $\begin{array}{l}\text { Leakage along sealed door } \\
\text { between } A-101 / 1 \text { and } A-108 / 1\end{array}$ & $A-101 / 1$ & CCR & $\begin{array}{l}\text { before } \\
\text { pressunization }\end{array}$ & eliminated \\
\hline 8. & $\begin{array}{l}\text { Defect in the outer shell of the } \\
\text { maintenance area MK KO "otm" } \\
10.5 \text { (behind exhaust chamber) }\end{array}$ & $A-101 / 1$ & KAER & $\begin{array}{l}\text { before power } \\
\text { start-up of } \\
\text { unit }\end{array}$ & eliminated \\
\hline 9. & $\begin{array}{l}\text { Leakage of air along the feedwater } \\
\text { piping and steam piping }\end{array}$ & $\begin{array}{l}\mathrm{A}-101 / 1 \\
\mathrm{~A}-002 / 1\end{array}$ & KAER & $\begin{array}{l}\text { before } \\
\text { pressurization }\end{array}$ & eliminated \\
\hline 10. & $\begin{array}{l}\text { Defect of outer shell at the BB } \\
\text { support (closest to the door to the } \\
\text { left of the entrance) }\end{array}$ & & KAER & $\begin{array}{l}\text { before power } \\
\text { start-up of } \\
\text { unit }\end{array}$ & eliminated \\
\hline
\end{tabular}




\begin{tabular}{|c|c|c|c|c|c|}
\hline 11. & $\begin{array}{l}\text { Defect of outer shell at the BB } \\
\text { support (second to the door closer } \\
\text { to "KO") }\end{array}$ & A-502/1 & KAER & $\begin{array}{l}\text { before } \\
\text { pressurization }\end{array}$ & eliminated \\
\hline 12. & $\begin{array}{l}\text { Defect of outer shell of the } \\
\text { maintenance area PK KO under } \\
\text { beam (on the wall opposite door } \\
\# 6 \text { ) }\end{array}$ & A-101/1 & KAER & $\begin{array}{l}\text { before } \\
\text { pressurization }\end{array}$ & eliminated \\
\hline 13. & $\begin{array}{l}\text { Passage of air from piping } \\
\text { "DU"150 (Air Pipe 150?) In the } \\
\text { floor under "KO" }\end{array}$ & A-1.01 & $\mathrm{CCR}$ & $\begin{array}{l}\text { before } \\
\text { pressurization }\end{array}$ & eliminated \\
\hline 14. & $\begin{array}{l}\text { Defect of outer shell of the floor } \\
\text { under } \mathrm{KO}\left(10^{*} 50 \mathrm{~mm}\right)\end{array}$ & $A-101 / 1$ & KAER & $\begin{array}{l}\text { before power } \\
\text { start-up of } \\
\text { unit }\end{array}$ & eliminated \\
\hline 15. & $\begin{array}{l}\text { Defect of outerfacing of the wall } \\
\text { behind } K O \text { at the level of the } \\
\text { heaters }\end{array}$ & A-101/1 & KAER & $\begin{array}{l}\text { before power } \\
\text { start-up of } \\
\text { unit }\end{array}$ & eliminated \\
\hline 16 & $\begin{array}{l}\text { Leakage along the outer housing } \\
\text { of the door lock between A-102/1 } \\
\text { - A-103/1 }\end{array}$ & A-102/1 & KAER & $\begin{array}{l}\text { before power } \\
\text { start-up of } \\
\text { unit }\end{array}$ & eliminated \\
\hline 17. & $\begin{array}{l}\text { In the floor under the KIP stand } \\
\text { (support) } 1 \mathrm{R}-2 / 5 \text { leakage along } \\
\text { perimeter of the square "packing" } \\
\left(150^{*} 150\right)\end{array}$ & A-102 & KAER & $\begin{array}{l}\text { before power } \\
\text { start-up of } \\
\text { unit }\end{array}$ & eliminated \\
\hline 18. & $\begin{array}{l}\text { Leakage along flanges of four } \\
\text { "DU" } 250 \text { Pipes on the inside wall } \\
\text { along } 1 \mathrm{r}-2 / 6\end{array}$ & A-102/1 & KAER & $\begin{array}{l}\text { before power } \\
\text { start-up of } \\
\text { unit }\end{array}$ & eliminated \\
\hline 19. & $\begin{array}{l}\text { Leakage of air along traps of } \\
\text { enclosure A-103/1 and deck of } \\
\text { GCN }\end{array}$ & $\begin{array}{l}\mathrm{A}-102 / 1 \\
\mathrm{~A}-103 / 1\end{array}$ & CCR & $\begin{array}{l}\text { before } \\
\text { pressurization }\end{array}$ & $\begin{array}{l}\text { inspected } \\
\text { valve SK- } \\
40\end{array}$ \\
\hline 20. & $\begin{array}{l}\text { Weak leak along flange of } \\
\text { "undercap" }\end{array}$ & & TTO & $\begin{array}{l}\text { before } \\
\text { pressurization }\end{array}$ & $\begin{array}{l}\text { sealed with } \\
\text { sealant }\end{array}$ \\
\hline 21. & $\begin{array}{l}\text { Leakage along two cable } \\
\text { penetrations to the left of door } \\
\text { ( } 2 \text { and } 3 \text { below) }\end{array}$ & $A-103 / 1$ & CTAI & $\begin{array}{l}\text { December } \\
1996\end{array}$ & eliminated \\
\hline 22. & $\begin{array}{l}\text { Leakage along welded seam } \\
\text { between seal and outerfacing in } \\
\text { corner ( } 7 \text { th pipe from the bottom) }\end{array}$ & $A-103 / 1$ & CTAI & $\begin{array}{l}\text { December } \\
1996\end{array}$ & eliminated \\
\hline
\end{tabular}




\begin{tabular}{|c|c|c|c|c|c|}
\hline 23. & $\begin{array}{l}\text { Defect of outerfacing of the wall } \\
\text { behind } 1 R-1 / 3\end{array}$ & $A-102 / 1$ & KAER & $\begin{array}{l}\text { before power } \\
\text { start-up of } \\
\text { unit }\end{array}$ & eliminated \\
\hline 24. & $\begin{array}{l}\text { Defects of welded seams at the } \\
\text { base/support of NDr }\end{array}$ & $A-102 / 1$ & KAER & $\begin{array}{l}\text { before power } \\
\text { start-up of } \\
\text { unit }\end{array}$ & eliminated \\
\hline 25. & $\begin{array}{l}\text { Defects of outerfacing of hatch } \\
\text { opening above NDr }\end{array}$ & $A-102 / 1$ & KAER & $\begin{array}{l}\text { Planned } \\
\text { Outage-97 }\end{array}$ & eliminated \\
\hline 26. & $\begin{array}{l}\text { Leakage along the lower left } \\
\text { corner of door between A-102/1 } \\
\text { and A-204/1 }\end{array}$ & $A-102 / 1$ & CCR & $\begin{array}{l}\text { Planned } \\
\text { Outage-97 }\end{array}$ & \\
\hline 27 & $\begin{array}{l}\text { Two defects of welded seams } \\
\text { along the perimeter } 1 \mathrm{R}-2 / 4\end{array}$ & A-102/1 & KAER & $\begin{array}{l}\text { before power } \\
\text { start-up of } \\
\text { unit }\end{array}$ & eliminated \\
\hline 28. & $\begin{array}{l}\text { Leakage along opening (near } \\
\text { panel 43) }\end{array}$ & $\begin{array}{l}\mathrm{A}-002 \\
\text { "mark"? } \\
\text { "otm"- } \\
1.8\end{array}$ & KAER & $\begin{array}{l}\text { before power } \\
\text { start-up of } \\
\text { unit }\end{array}$ & eliminated \\
\hline 29. & $\begin{array}{l}\text { Two defects of outerfacing in the } \\
\text { flooring near the area of loop } 6\end{array}$ & $\begin{array}{l}\text { A-002 } \\
\text { "mark"? } \\
\text { "otm"- } \\
1.8\end{array}$ & KAER & $\begin{array}{l}\text { before power } \\
\text { start-up of } \\
\text { unit }\end{array}$ & eliminated \\
\hline 30. & $\begin{array}{l}\text { Leakage along two seams in the } \\
\text { flooring near the area of loop } 6\end{array}$ & $\begin{array}{l}\text { A-002 } \\
\text { "mark"? } \\
\text { "otm"- } \\
1.8\end{array}$ & KAER & $\begin{array}{l}\text { before power } \\
\text { start-up of } \\
\text { unit }\end{array}$ & eliminated \\
\hline 31. & $\begin{array}{l}\text { Defect in the outerfacing behind } \\
\text { Power Generator } 4 \text { on the wall } \\
\text { near the stairs under the platform }\end{array}$ & $\begin{array}{l}\text { A-002 } \\
\text { "mark"? } \\
\text { "otm"-1.8 }\end{array}$ & KAER & $\begin{array}{l}\text { before power } \\
\text { start-upof unit }\end{array}$ & eliminated \\
\hline 32. & $\begin{array}{l}\text { Defect of the outerfacing of the } \\
\text { floor behind the cold filament of } \\
\text { steam generator-3 at the stearn } \\
\text { generator platform column (axis } \\
\text { 32) }\end{array}$ & $\begin{array}{l}\text { A-002 } \\
\text { mark } \\
\text { "otm"- } \\
1.8\end{array}$ & KAER & $\begin{array}{l}\text { before power } \\
\text { start-up of } \\
\text { unit }\end{array}$ & eliminated \\
\hline
\end{tabular}




\begin{tabular}{|c|c|c|c|c|c|}
\hline 33. & $\begin{array}{l}\text { Defect in opening No. } 5 \text { (second } \\
\text { from bottom in the row of } \\
\text { openings)to the left of the } \\
\text { entrance to A-213/1 }\end{array}$ & $\begin{array}{l}\text { A-002 } \\
\text { mark } \\
\text { "otm"- } \\
1.8\end{array}$ & KAER & $\begin{array}{l}\text { before power } \\
\text { start-up of } \\
\text { unit }\end{array}$ & eliminated \\
\hline 34. & $\begin{array}{l}\text { Defect in the outerfacing along } \\
\text { floor - wall joint between SG-2 } \\
\text { and SG-3 (axis } 34 \text { ) }\end{array}$ & $\begin{array}{l}\mathrm{A}-002 \\
\text { mark } \\
\text { "otm'1.8 }\end{array}$ & KAER & $\begin{array}{l}\text { before power } \\
\text { start-up of } \\
\text { unit }\end{array}$ & eliminated \\
\hline 35. & $\begin{array}{l}\text { Defect in the outerfacing along } \\
\text { floor - wall joint behind SG-1 (to } \\
\text { the left of the cable tray) }\end{array}$ & $\begin{array}{l}\text { A-002 } \\
\text { mark } \\
\text { "otm"- } \\
1.8\end{array}$ & KAER & $\begin{array}{l}\text { before power } \\
\text { start-up of } \\
\text { unit }\end{array}$ & eliminated \\
\hline 36. & $\begin{array}{l}\text { Defect of the outerfacing of the } \\
\text { wall behind pipes behind the SG- } \\
1 \text { (above the "KIP" pipe } \\
\text { penetrations ) }\end{array}$ & $\begin{array}{l}\text { A-002 } \\
\text { mark } \\
\text { "otm"- } \\
1.8\end{array}$ & KAER & $\begin{array}{l}\text { before power } \\
\text { start-up of } \\
\text { unit }\end{array}$ & eliminated \\
\hline 37. & $\begin{array}{l}\text { Leakage along the support frame } \\
\text { under GCH-2,3 }\end{array}$ & $\begin{array}{l}\text { A-002 } \\
\text { mark } \\
\text { "otm" } \\
-1.8\end{array}$ & KAER & $\begin{array}{l}\text { befor power } \\
\text { start-up of } \\
\text { unit }\end{array}$ & eliminated \\
\hline 38. & $\begin{array}{l}\text { Defects in the frame of the hot } \\
\text { GZZ } 3 \text { loops (between the box } \\
\text { and deck) }\end{array}$ & $\begin{array}{l}\text { A-002 } \\
\text { marking - } \\
1.8\end{array}$ & KAER & $\begin{array}{l}\text { before power } \\
\text { start-up of } \\
\text { unit }\end{array}$ & eliminated \\
\hline 39. & $\begin{array}{l}\text { Defect in the outerseal behind the } \\
\text { door in the comer }\end{array}$ & A-105/1 & KAER & $\begin{array}{l}\text { Power } \\
\text { Outage-97 }\end{array}$ & \\
\hline 40. & $\begin{array}{l}\text { Leakage from beneath the flange } \\
\text { bolts } \mathrm{K}-12 / 5 \text { and } \mathrm{K}-11 / 4\end{array}$ & A-106/1 & CEOO & $\begin{array}{l}\text { before } \\
\text { pressurization }\end{array}$ & eliminated \\
\hline 41. & $\begin{array}{l}\text { Leakage under two cable } \\
\text { penetrations above the door }\end{array}$ & $A-013 / 1$ & CTAI & $\begin{array}{l}\text { Power } \\
\text { Outage-97 } \\
\end{array}$ & eliminated \\
\hline 42. & $\begin{array}{l}\text { Leakage along cable penetration } \\
\text { flange in A-012/1 (to the left of } \\
\text { entrance door) }\end{array}$ & A-013/1 & KAER & $\begin{array}{l}\text { Power } \\
\text { Outage-97 }\end{array}$ & \\
\hline 43. & $\begin{array}{l}\text { Defect in the outerseal of the wall } \\
\text { between A-013/1 and A-002/1 }\end{array}$ & A-013/1 & KAER & $\begin{array}{l}\text { Power } \\
\text { Outage-97 }\end{array}$ & \\
\hline 44. & $\begin{array}{l}\text { Leakage along welded seam and } \\
\text { the packing of the trap }\end{array}$ & $A-013 / 1$ & CCR & $\begin{array}{l}\text { before } \\
\text { pressurization }\end{array}$ & $\begin{array}{l}\text { trap has } \\
\text { been } \\
\text { inspected. }\end{array}$ \\
\hline
\end{tabular}




\begin{tabular}{|c|c|c|c|c|c|}
\hline 45. & $\begin{array}{l}\text { Defect in the outerseal of the } \\
\text { ceiling between } 1 \text { PG- } 6 \text { and cable } \\
\text { shaft }\end{array}$ & A-002/1 & KAER & $\begin{array}{l}\text { before power } \\
\text { start-up of } \\
\text { unit }\end{array}$ & eliminated \\
\hline 46. & $\begin{array}{l}\text { Leakage along flange of piping/ } \\
\text { conduit penetration behind } 1 \text { PG- } \\
2 \cdot(3 \mathrm{~m} \text { from bottom of the annular } \\
\text { platform })\end{array}$ & $\begin{array}{l}\text { A-002/1 } \\
\text { Top }\end{array}$ & KAER & $\begin{array}{l}\text { before power } \\
\text { start-up of } \\
\text { unit }\end{array}$ & eliminated \\
\hline 47. & $\begin{array}{l}\text { Behind } 1 \text { PG-2 leakage along two } \\
\text { flanges of conduit penetrations }\end{array}$ & $\begin{array}{l}\mathrm{A}-002 / 1 \\
\text { top }\end{array}$ & KAER & $\begin{array}{l}\text { before power } \\
\text { start-up of } \\
\text { unit }\end{array}$ & eliminated \\
\hline 48. & $\begin{array}{l}\text { Two defects in the outerfacing on } \\
\text { the wall behind } 1 S G-3 \text { (near the } \\
\text { top maintainance platform }\end{array}$ & $\begin{array}{l}\text { A-002/1 } \\
\text { top }\end{array}$ & KAER & $\begin{array}{l}\text { before power } \\
\text { start-up of } \\
\text { unit }\end{array}$ & eliminated \\
\hline 49. & $\begin{array}{l}\text { Two defects of openings in the } \\
\text { wall next to "KO" }\end{array}$ & A-101/1 & KAER & $\begin{array}{l}\text { before power } \\
\text { start-up of } \\
\text { unit }\end{array}$ & eliminated \\
\hline 50. & $\begin{array}{l}\text { Defect in the outerfacing of the } \\
\text { wall near the top maintenance } \\
\text { platform !SG-1 (near the } \\
\text { feedwater piping conduits from } \\
\text { the SG-1 facing) }\end{array}$ & $\begin{array}{l}A-002 / 1 \\
\text { top }\end{array}$ & KAER & $\begin{array}{l}\text { before power } \\
\text { start-up of } \\
\text { unit }\end{array}$ & eliminated \\
\hline 51. & $\begin{array}{l}\text { Defect in the outerfacing on the } \\
\text { wall along } 1 \text { SG-1 (near the } \\
\text { feedwater piping conduits) }\end{array}$ & $\begin{array}{l}\text { A-002/1 } \\
\text { top }\end{array}$ & KAER & $\begin{array}{l}\text { before power } \\
\text { start-up of } \\
\text { unit }\end{array}$ & eliminated \\
\hline 52. & $\begin{array}{l}\text { Defect in the outerfacing on the } \\
\text { wall betwee SG-5 and the } \\
\text { exploding-valve platform (under } \\
\text { the ceiling) }\end{array}$ & $\begin{array}{l}A-002 / 1 \\
\text { top }\end{array}$ & KAER & $\begin{array}{l}\text { before power } \\
\text { start-up of } \\
\text { unit }\end{array}$ & eliminated \\
\hline 53. & $\begin{array}{l}\text { Defect in the outerfacing near the } \\
\text { feedwater piping conduit support } \\
\text { between SG-5 and SG-6 }\end{array}$ & $\begin{array}{l}\text { A-002/1 } \\
\text { top }\end{array}$ & KAER & $\begin{array}{l}\text { before power } \\
\text { start-up of } \\
\text { unit }\end{array}$ & eliminated \\
\hline 54. & $\begin{array}{l}\text { Defect in the outerfacing above } \\
\text { the openings for the steam piping } \\
\text { mark "otm" } 14.0\end{array}$ & $\begin{array}{l}\text { A-002/1 } \\
\text { top }\end{array}$ & KAER & $\begin{array}{l}\text { before power } \\
\text { start-up of } \\
\text { unit }\end{array}$ & elliminted \\
\hline 55. & $\begin{array}{l}\text { Defect in the outerfacing near the } \\
\text { supports for piping conduits for } \\
\text { the sprinkling system }\end{array}$ & $\begin{array}{l}\text { A-002/1 } \\
\text { top }\end{array}$ & KAER & $\begin{array}{l}\text { before power } \\
\text { start-up of } \\
\text { unit }\end{array}$ & eliminated \\
\hline
\end{tabular}




\begin{tabular}{|c|c|c|c|c|c|}
\hline 56. & $\begin{array}{l}\text { Leakage through the breathing } \\
\text { hatches/vents of the biological } \\
\text { shield along the ceiling. }\end{array}$ & A-001/1 & & $\begin{array}{l}\text { Power } \\
\text { Outage-97 }\end{array}$ & $\begin{array}{l}\text { separate } \\
\text { measures }\end{array}$ \\
\hline 57. & $\begin{array}{l}\text { Small leak in the opening of } \\
\text { DU200 (air duct?) }\end{array}$ & A-001/1 & KAER & $\begin{array}{l}\text { Power outage- } \\
97\end{array}$ & \\
\hline 58. & Replace screw in top rack of door & A-004/1 & CCR & $\begin{array}{l}\text { before } \\
\text { pressurization }\end{array}$ & eliminated \\
\hline 59. & $\begin{array}{l}\text { Leakage along flanges of openings } \\
1 Y 1-9,12,19\end{array}$ & A-106/1 & KAER & $\begin{array}{l}\text { December } \\
1996\end{array}$ & \\
\hline 60. & $\begin{array}{l}\text { Leakage along hatch seal above } \\
\text { NDr-1 }\end{array}$ & A-301 & TTO & $\begin{array}{l}\text { Power } \\
\text { Outage-97 }\end{array}$ & \\
\hline 61. & $\begin{array}{l}\text { Undampen trap a-311/1 from trap } \\
\text { A 303/1 }\end{array}$ & A-303/1 & CCR & $\begin{array}{l}\text { before } \\
\text { pressurization }\end{array}$ & completed \\
\hline 62. & $\begin{array}{l}\text { Leakage along cable } \\
\text { openings/penetrations ( } 3 \text { items) } \\
\text { near door no. A-502/1 }\end{array}$ & A-501/1 & CTAI & $\begin{array}{l}\text { Power } \\
\text { Outage-97 }\end{array}$ & eliminted \\
\hline 63. & $\begin{array}{l}\text { Crack along welded seam on the } \\
\text { maintainance platform for } \\
\text { exploding valves near stairs } \\
\text { leading to shutoff valve }\end{array}$ & $\begin{array}{l}\mathrm{A}-002 / 1 \\
\text { top }\end{array}$ & KAER & $\begin{array}{l}\text { before power } \\
\text { start-up of } \\
\text { unit }\end{array}$ & eliminated \\
\hline 64. & $\begin{array}{l}\text { Leakage from the } \\
\text { opening/penetration }(10 \mathrm{~mm}) \text { on } \\
\text { the top platform, left wall }\end{array}$ & A-207/1 & KAER & $\begin{array}{l}\text { Power } \\
\text { Outage-97 }\end{array}$ & \\
\hline 65. & $\begin{array}{l}\text { Leakage along cable penetration } \\
\text { ( } 4 \text { pipes) behind } 1 S G-4\end{array}$ & A-104/1 & CTAI & $\begin{array}{l}\text { Power } \\
\text { Outage-97 }\end{array}$ & eliminated \\
\hline 66. & $\begin{array}{l}\text { Leakage along cable penetration } \\
\text { (1 pipe) (left wall) }\end{array}$ & A-104/1 & CTAI & $\begin{array}{l}\text { Power } \\
\text { Outage-97 }\end{array}$ & eliminated \\
\hline 67. & $\begin{array}{l}\text { Leakage along cable penetration } \\
\text { (1 pipe) (opening above door)E- } \\
205\end{array}$ & A-308/1 & CTAI & $\begin{array}{l}\text { Power } \\
\text { Outage-97 }\end{array}$ & eliminated \\
\hline 68. & $\begin{array}{l}\text { Leakage along cable penetration } \\
\text { (1 pipe) (opening above door) E- } \\
219\end{array}$ & A-502/1 & CTAI & $\begin{array}{l}\text { Power } \\
\text { Outage-97 }\end{array}$ & eliminated \\
\hline
\end{tabular}




\begin{tabular}{|c|l|l|l|l|l|}
\hline 69. & $\begin{array}{l}\text { Leakage along cable penetration } \\
(5 \text { pipes }) \text { E-8 }\end{array}$ & A-002 & CTI & $\begin{array}{l}\text { Power } \\
\text { Outage-97 }\end{array}$ & eliminated \\
\hline 70. & $\begin{array}{l}\text { Leakage along cable penetration } \\
(2 \text { pipes }) \text { E-54 }\end{array}$ & A-103/1 & CTAI & $\begin{array}{l}\text { Power } \\
\text { Outage-97 }\end{array}$ & eliminated \\
\hline 71. & $\begin{array}{l}\text { Leakage along cable penetration } \\
(5 \text { pipes }) \text { E-7 }\end{array}$ & A-004/1 & CTAI & $\begin{array}{l}\text { Power } \\
\text { Outage-97 }\end{array}$ & eliminated \\
\hline 72. & $\begin{array}{l}\text { Leakage along cable penetration } \\
\text { E-6a }\end{array}$ & A-004/2 & CTAI & $\begin{array}{l}\text { Power } \\
\text { Outage-97 }\end{array}$ & eliminted \\
\hline & & & & & \\
\hline
\end{tabular}

DISCOVERED DURING PRESSURIZATION

\begin{tabular}{|l|l|l|l|l|l|}
\hline 1. & $\begin{array}{l}\text { Weak leak along reserve/backup } \\
\text { cable penetrations (first } \\
\text { penetration/opening from the } \\
\text { entrance on the the left side of the } \\
\text { floor) }\end{array}$ & A-201/1 & CTAI & January-97 & eliminated \\
\hline 2. & $\begin{array}{l}\text { Leakage along cable penetrations } \\
\text { 2 pipes (to the left on the wall } \\
\text { across from SK-9 IVM) }\end{array}$ & A-203/1 & CTAI & January-97 & eliminated \\
\hline 3. & $\begin{array}{l}\text { Leakage along cable penetration - } \\
5 \text { pipes (on the vertical wall } \\
\text { across SK-4 IM), caps not } \\
\text { tightened on all reserve openings }\end{array}$ & A-203/1 & CTAI & January-97 & eliminated \\
\hline 4. & $\begin{array}{l}\text { Leakage along cable penetration } \\
13 \text { pipes (on the vertical wall } \\
\text { across from cHzck-6) }\end{array}$ & A-203/1 & CTAI & January-97 & eliminated \\
\hline 5. & $\begin{array}{l}\text { Leakage along the reserve cable } \\
\text { penetration }\end{array}$ & A-008/1 & CTAI & January-97 & eliminated \\
\hline 6. & $\begin{array}{l}\text { Leakage along cable penetration } \\
\text { on the right, bottom outside) }\end{array}$ & A-008/2 & CTAI & January-97 & eliminated \\
\hline
\end{tabular}




\begin{tabular}{|c|c|c|c|c|c|}
\hline 7. & $\begin{array}{l}\text { Leakage along flange of piping } \\
\text { conduit from A-306/1 into A- } \\
502 / 1\end{array}$ & A-502/1 & KAER & $\begin{array}{l}\text { December } \\
1996\end{array}$ & \\
\hline 8. & $\begin{array}{l}\text { Leakage along piping conduit } \\
\text { flanges PK SUZ }\end{array}$ & A-108/1 & KAER & $\begin{array}{l}\text { December } \\
1996\end{array}$ & \\
\hline 9. & Unsealed hatch above $\mathrm{Hdr}-1$ & $A-301$ & EC & $\begin{array}{l}\text { Power } \\
\text { Outage-97 }\end{array}$ & \\
\hline 10. & $\begin{array}{l}\text { Leakage along cable penetration } \\
\text { (second along the walkway) }\end{array}$ & E-002/4 & EC & $\begin{array}{l}\text { Power } \\
\text { Outage-97 }\end{array}$ & eliminated \\
\hline 11 . & $\begin{array}{l}\text { Leakage along cable penetration } \\
\text { (last one) }\end{array}$ & $\mathrm{E}-002 / 4$ & $\mathrm{EC}$ & \begin{tabular}{|l|l} 
Power \\
Outage-97 \\
\end{tabular} & eliminated \\
\hline 12 . & $\begin{array}{l}\text { 1-P-1-5: } \\
\text {-leakage along armored plate } \\
\text { separations/seams } \\
\text {-leakage from under pressure } \\
\text { flange of gasket in the top portion }\end{array}$ & B- $005 / 1$ & CEOO & $\begin{array}{l}\text { Power } \\
\text { Outage-97 }\end{array}$ & eliminated \\
\hline 13. & $\begin{array}{l}\text { 1-P-1-4: } \\
\text {-leakage from under pressure cap; } \\
\text {-leakage along outside edge of } \\
\text { ring; } \\
\text {-leakage along syphon seal }\end{array}$ & $b-005 / 1$ & CEOO & $\begin{array}{l}\text { Power } \\
\text { Outage-97 } \\
\text { Power } \\
\text { Outage-97 }\end{array}$ & $\begin{array}{l}\text { eliminated } \\
\text { during } \\
\text { testing }\end{array}$ \\
\hline 14. & $\begin{array}{l}\text { Leakage along flanges of service } \\
\text { water piping conduits. } \\
-1 \text { P } 1-3 \text { entrance; } \\
\text {-next to armour for } 1 T-16 / 2 \\
-1 P-1-1 \text { next to armour for } 1 T \text { - } \\
17 / 1\end{array}$ & B-005/1 & CEOO & $\begin{array}{l}\text { Power } \\
\text { Outage-97 }\end{array}$ & eliminated \\
\hline 15. & $\begin{array}{l}\text { Leakage along seal of man-hole } \\
\text { hatch to the air duct } P-1\end{array}$ & B-004/1 & CEOO & $\begin{array}{l}\text { Power } \\
\text { Outage-97 }\end{array}$ & \\
\hline 16. & $\begin{array}{l}\text { Leakage along cable penetrations } \\
\text { (along top) between A-103/1 and } \\
\text { B-114/1 }\end{array}$ & B-114/1 & CTAI & Janauary-97 & eliminated \\
\hline 17. & $\begin{array}{l}\text { Leakage along piping flange (to } \\
\text { the left) }\end{array}$ & B--114/1 & KAER & $\begin{array}{l}\text { Power } \\
\text { Outage-97 }\end{array}$ & \\
\hline
\end{tabular}




\begin{tabular}{|c|c|c|c|c|c|}
\hline 18. & $\begin{array}{l}\text { Leakage along cable penetrations } \\
\text { between A-004/2 and A-014/1 }\end{array}$ & $A-004 / 2$ & CTAI & $\begin{array}{l}\text { Power } \\
\text { Outage-97 }\end{array}$ & eliminated \\
\hline 19. & $\mathrm{~K}-11 / 5$ leakage along flange seam & A-301 & CEOO & $\begin{array}{l}\text { Power } \\
\text { Outage-97 }\end{array}$ & \\
\hline 20. & $\begin{array}{l}\text { Re-seal man-hole hatch infront of } \\
\text { "G/K" } 1 G-1\end{array}$ & $A-304$ & CEOO & $\begin{array}{l}\text { Power } \\
\text { Outage-97 }\end{array}$ & \\
\hline 21. & $\begin{array}{l}\text { Leakage through seal of man-hole } \\
\text { hatch in front of " } g / k \text { " } 1 \mathrm{~B}-4\end{array}$ & B-213/1 & CEOO & $\begin{array}{l}\text { Power } \\
\text { Outage-97 }\end{array}$ & \\
\hline 22. & $\begin{array}{l}\text { Leakage from "burn-through" of } \\
\text { air duct along the support in front } \\
\text { of the first gate-valve }\end{array}$ & $b-213 / 1$ & CEOO & $\begin{array}{l}\text { Power } \\
\text { Outage-97 }\end{array}$ & \\
\hline 23. & $\begin{array}{l}\text { Connector/terminal improperly } \\
\text { possitioned 1B-4 }\end{array}$ & $\mathrm{B}-213 / 1$ & CTAI & $\begin{array}{l}\text { before power } \\
\text { start-up of } \\
\text { unit }\end{array}$ & eliminated \\
\hline 24. & $\begin{array}{l}\text { Re-seal flange in front of " } \mathrm{g} / \mathrm{k} 1 \mathrm{~A}- \\
4 / 3\end{array}$ & A-304 & CEOO & $\begin{array}{l}\text { Power } \\
\text { Outage-97 }\end{array}$ & \\
\hline 25. & $\begin{array}{l}\text { Leakage along cable penetration } \\
\text { near door A-103/1 }\end{array}$ & B-105/1 & CTAI & January-97 & eliminated \\
\hline 26. & Re-seal flange K-12/5 & A-106/1 & CEOO & $\begin{array}{l}\text { Power } \\
\text { Outage-97 }\end{array}$ & \\
\hline 27. & $\begin{array}{l}\text { Leakages along perimeter of } \\
\text { piston/rod penetrations }\end{array}$ & $\mathrm{A}-107 / 1$ & KAER & $\begin{array}{l}\text { Power } \\
\text { Outage-97 }\end{array}$ & \\
\hline 28. & $\begin{array}{l}\text { Leakages along two cut } \\
\text { penetrations in the left corner } \\
\text { behind armour 1PK-1 }\end{array}$ & $\mathrm{A}-108 / 1$ & KAER & $\begin{array}{l}\text { Power } \\
\text { Outage-97 }\end{array}$ & \\
\hline 29. & $\begin{array}{l}\text { Leakage along two cable } \\
\text { penetrations (to the left-over the } \\
\text { door) }\end{array}$ & $A-503 / 1$ & CTAI & January-97 & eliminated \\
\hline 30. & $\begin{array}{l}\text { Leakage along flange of piping } \\
\text { conduit DU57 (under the support } \\
\text { next to hatch GCH-2) }\end{array}$ & A-301 & KAER & December-96 & eliminated \\
\hline 31. & $\begin{array}{l}\text { Leakage along flange of feedwater } \\
\text { conduit } 1 \mathrm{PG}-3\end{array}$ & $\begin{array}{l}\text { mark } 14 \\
\text { machine } \\
\text { hall }\end{array}$ & KAER & $\begin{array}{l}\text { before power } \\
\text { start-up of } \\
\text { unit }\end{array}$ & eliminated \\
\hline
\end{tabular}




\begin{tabular}{|l|l|l|l|l|l|}
\hline 32. & $\begin{array}{l}\text { Leakage along flange of reserve } \\
\text { opening (emergency opening) } \\
\text { DU400 on the wall behind piping } \\
\text { conduits for feedwater 1PG-1-3 }\end{array}$ & $\begin{array}{l}\text { mark 14 } \\
\text { machine } \\
\text { hall }\end{array}$ & KAER & December-96 & \\
\hline 33. & $\begin{array}{l}\text { Escape of air through KID of the } \\
\text { ventillation system P-4 }\end{array}$ & E-501 & & $\begin{array}{l}\text { fabricate } \\
\text { hermetic } \\
\text { valves }\end{array}$ \\
\hline
\end{tabular}

Director GLSB CNIP

Petkevich T.I. 


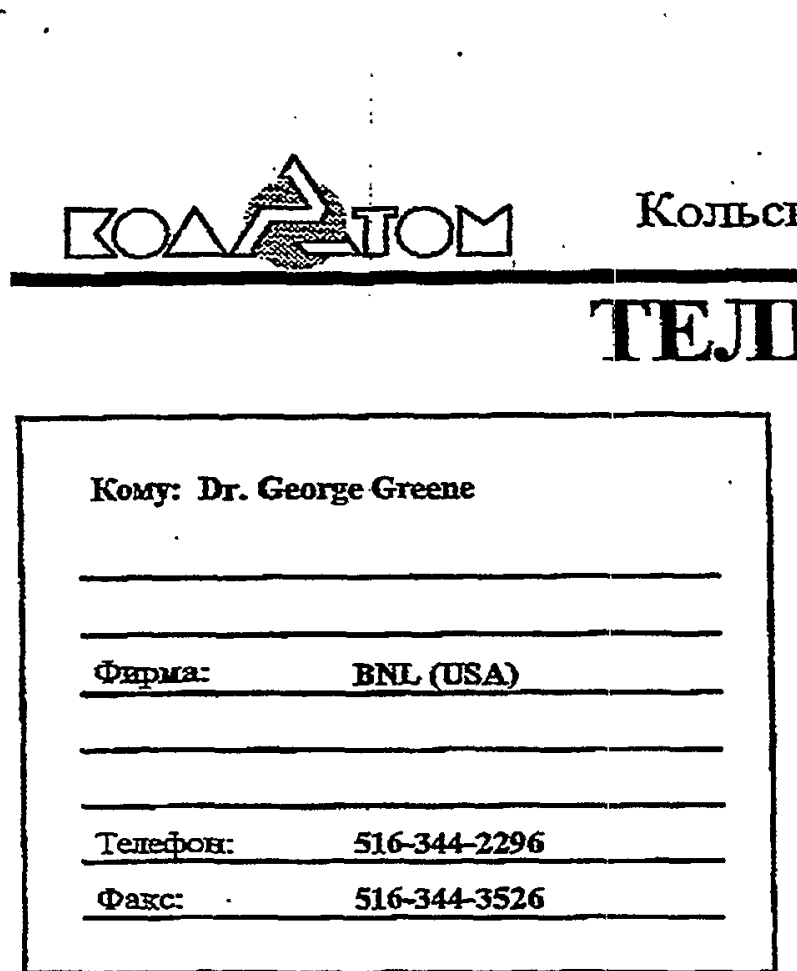

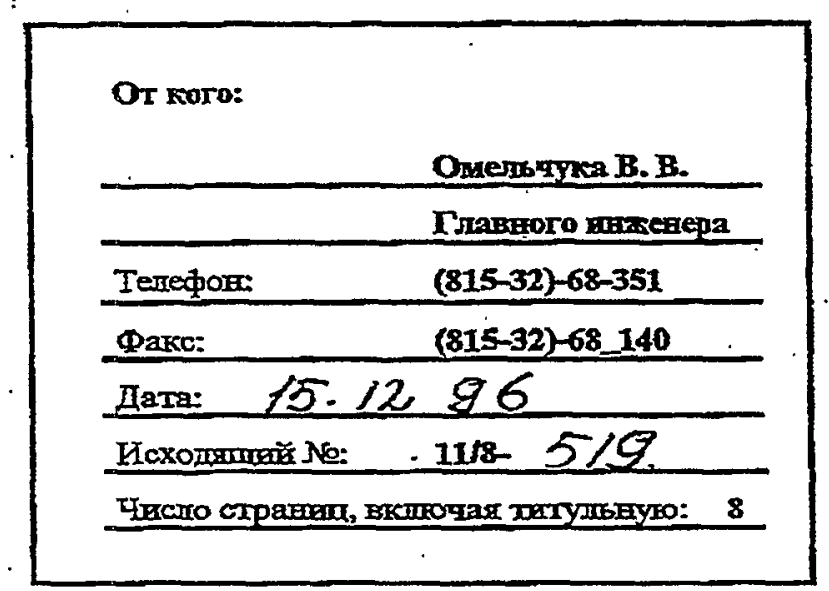

\section{Уважаемытй г. Грин!}

Направляо Вам акт об внтетралшных шспытанпях гермообъема (TO) блока 1 посте

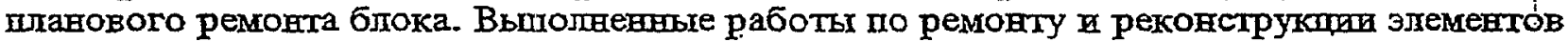

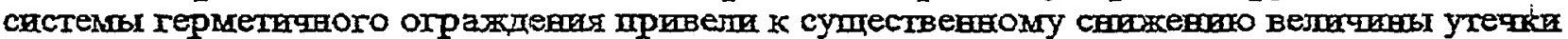

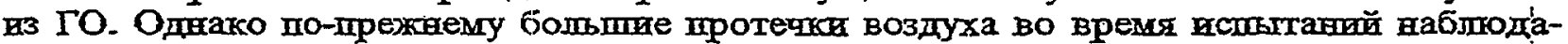

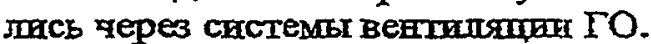

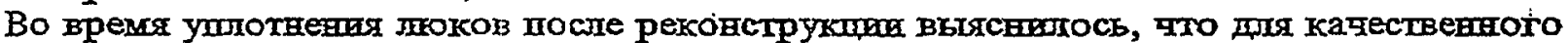
вх уплотнения веобходима рељина меньмей твердости, пем та, тто уже былта равее Вамп поставлена на Кольскуюо АЭС в размером $15 \times 20$ мак (вместо 15×30). Пропу Вас рассмотреть вопрос о возможности поставка такой резивы на КАЭС. Необходимое колпдество рездеы указаво в факсе Кольской АЭС 치 1/8-448 от 16.10.96r.

В еженедепном отчете о проделанной работе от 25.10.96г. по Международной иро-

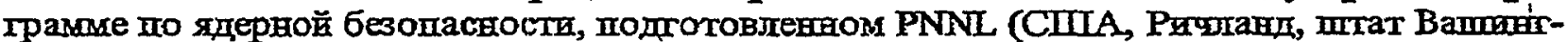
тон) указано, тто персоналом Аргонской Напрональной Лабораторип (ANL) подтотов-

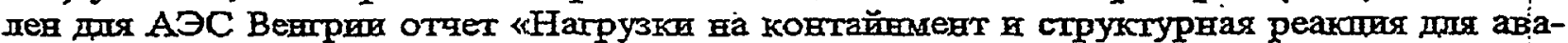
рши с разрљпом трубоировода больтого дтаметра на АЭС с реаклором ВВЭР-440/213»

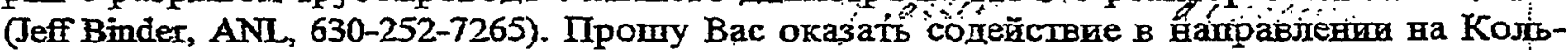

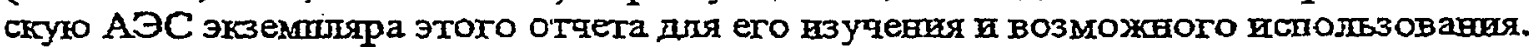

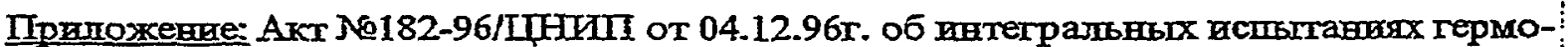
объема (ГO) блока 1 посте штавового ремонта блока на 7 ластах в 1 эка.

C уважением

Главный инженер

IItexcersers, 29-71

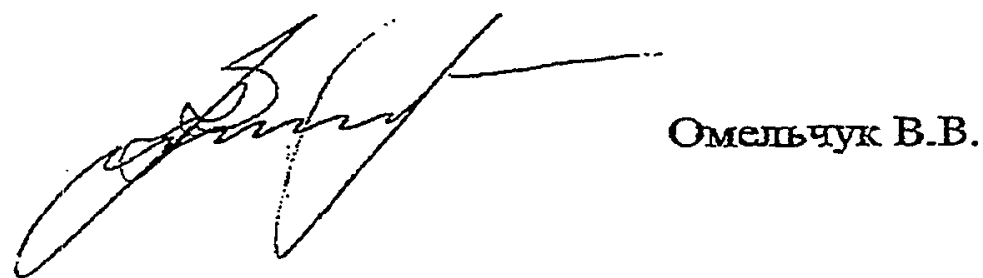




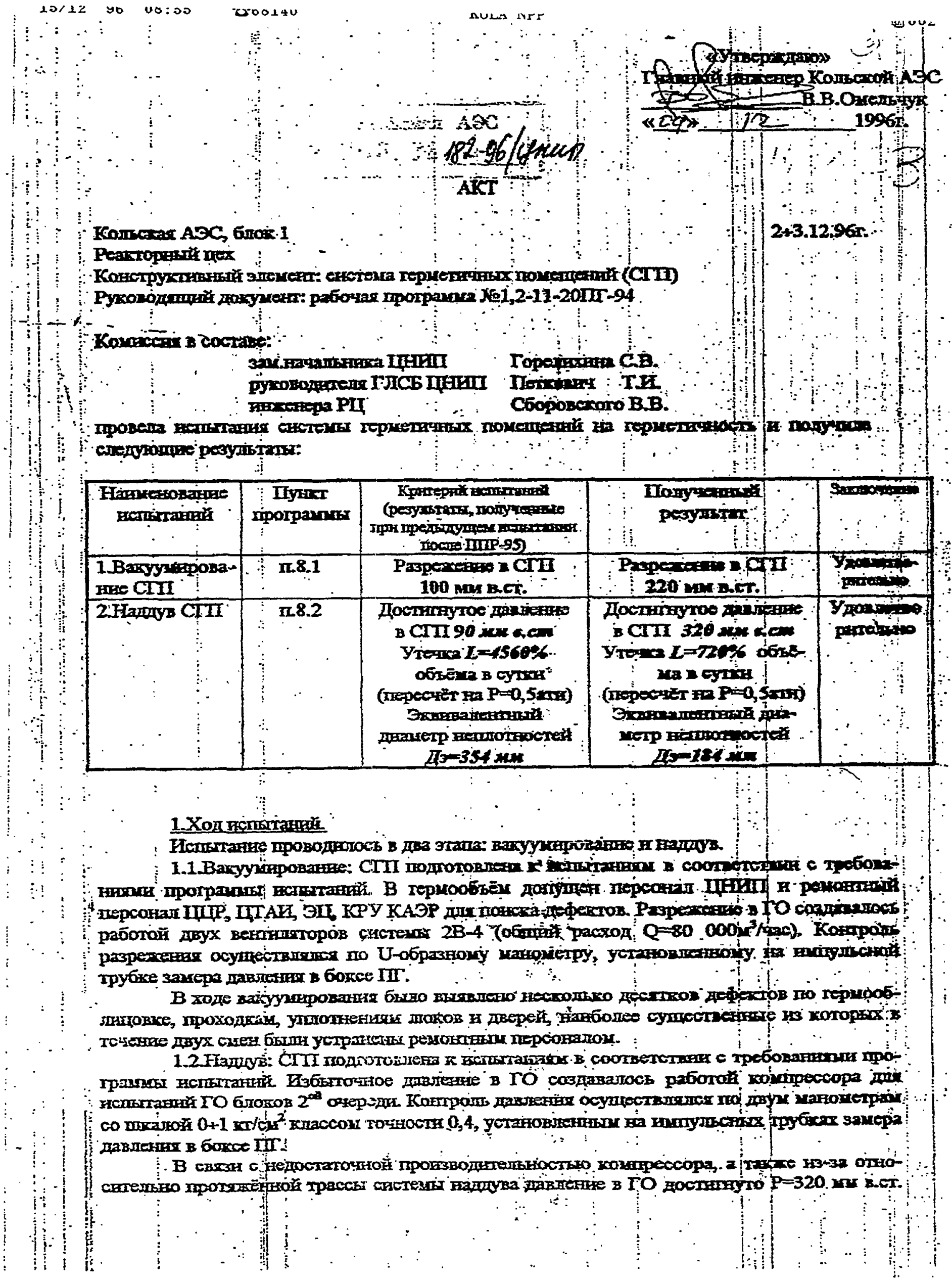




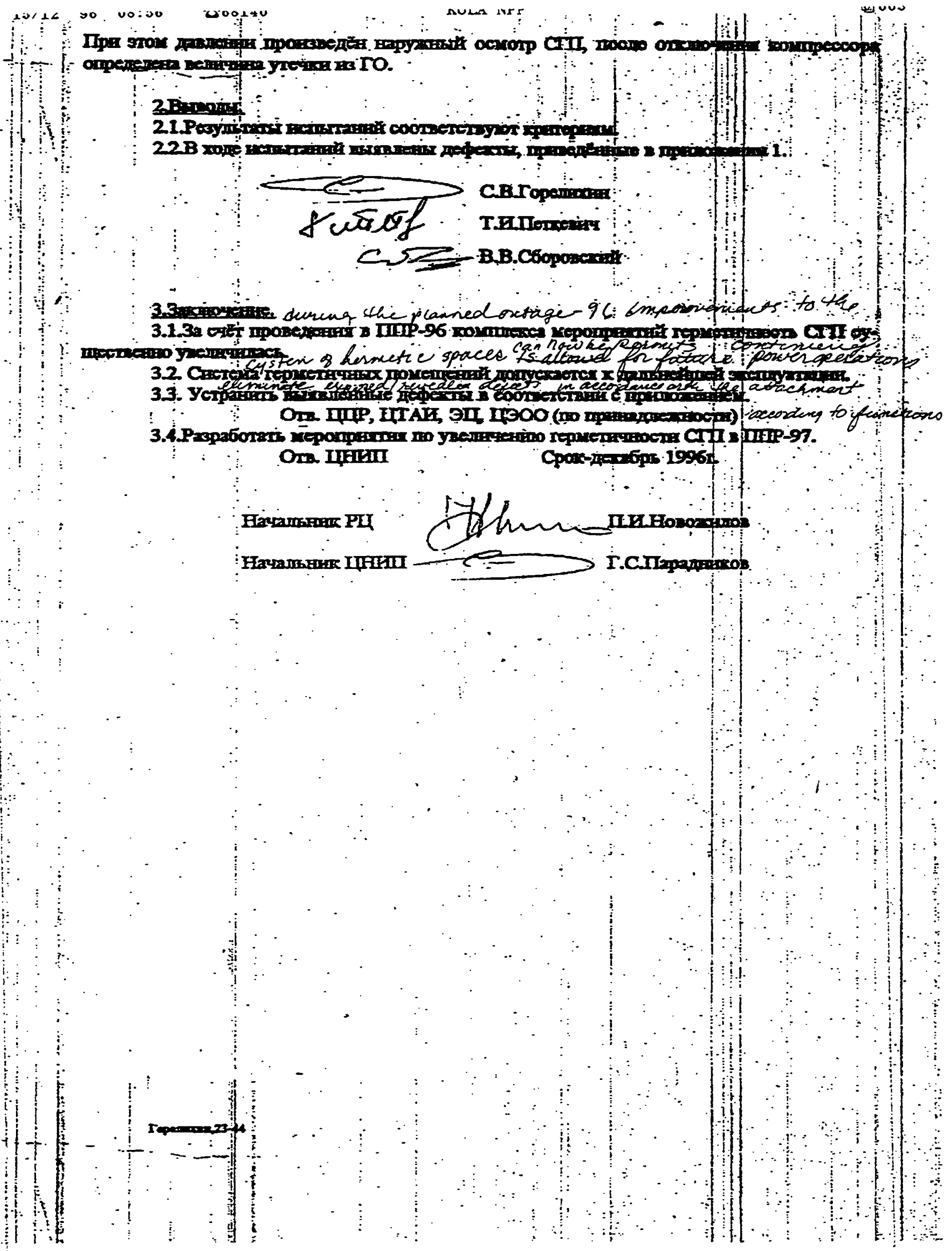




\begin{tabular}{|c|c|c|c|c|c|}
\hline $\begin{array}{l}\text { No } \\
\mathbf{n} / \mathbf{x}\end{array}$ & Намменованаяе & $\begin{array}{l}\text { NoNe } \\
\text { गOM. }\end{array}$ & $\begin{array}{c}\text { Orr. } 3 a \\
\text { yctpare } \\
\text { mare }\end{array}$ & $\begin{array}{l}\text { Cpor ycт- } \\
\text { panenar }\end{array}$ & $\begin{array}{c}\text { Ipromerta- } \\
\text { mare }\end{array}$ \\
\hline \multicolumn{6}{|c|}{ 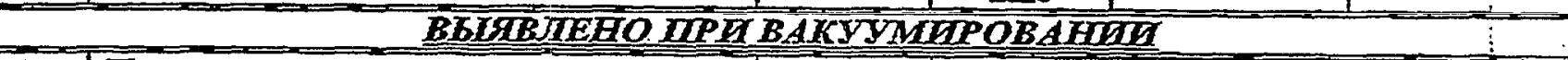 } \\
\hline 1. & Iропуск воздуха по сашынаку К $-11 / 1$ & $A-105 / 1$ & LPOOO & доо налтува & устранено \\
\hline 2. & Iропуск воздуха по сапвнику $\mathrm{K}-12 / 14$ & A-109/1 & 1300 & до ваддуува & устравено \\
\hline 3. & Не настроев кониевик $\mathrm{K}-11 / 18$ & $A-108 / 1$ & ITIAU & до наплува & устранено \\
\hline 4. & $\begin{array}{l}\text { Переупто тнить люок-лаз воздуховода } \\
\text { 1В-1 перед г/к IГ-1 }\end{array}$ & B-304 & ЦЗ00 & IIIIP-97 & \\
\hline 5. & 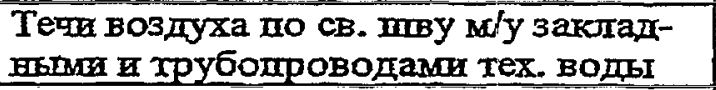 & IB-005 & KAЭP & $\begin{array}{l}\text { декабрь } \\
1996 \mathrm{r} \text {. }\end{array}$ & 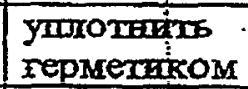 \\
\hline 6. & 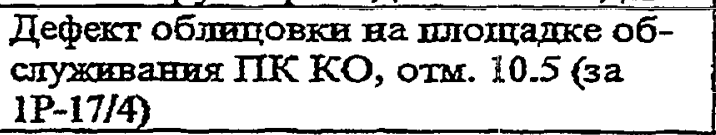 & $A-101 / 1$ & KAЭP & $\begin{array}{l}\text { до пуска } \\
\text { блока }\end{array}$ & устранено \\
\hline 7. & 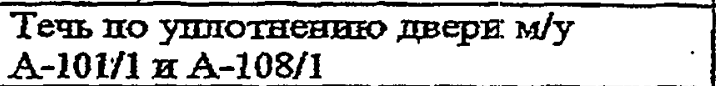 & A-101/1 & ІІЩP & до наддува & уетран \\
\hline 8. & 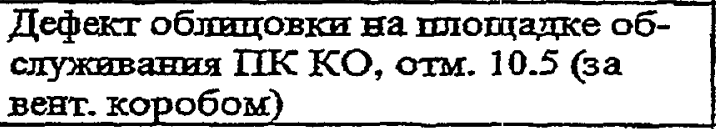 & $\mathrm{A}-101 / 1$ & KAFP & $\begin{array}{l}\text { до пуска } \\
\text { блока }\end{array}$ & устравено \\
\hline 9. & $\begin{array}{l}\text { Тесп воздуха вдоль труботроводов } \\
\text { питательой воды в паропроводов }\end{array}$ & $\begin{array}{l}\mathrm{A}-101 / 1 \\
\mathrm{~A}-002 / 1\end{array}$ & $\mathrm{KAOP}$ & до наддува & устраненіо \\
\hline 10. & 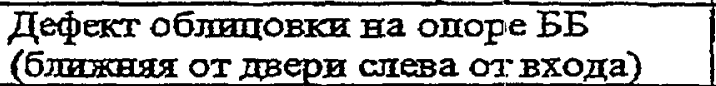 & & $\mathrm{KAOP}$ & $\begin{array}{l}\text { до пуска } \\
\text { блока }\end{array}$ & устранено \\
\hline 11. & $\begin{array}{l}\text { Дефект обличовки на опоре ББ } \\
\text { (следугошая от двери блшже ж КО) }\end{array}$ & $A-502 / I$ & $\overline{\mathrm{KAOP}}$ & $\begin{array}{l}\text { до пуска } \\
\text { блока }\end{array}$ & yстрав \\
\hline 12. & 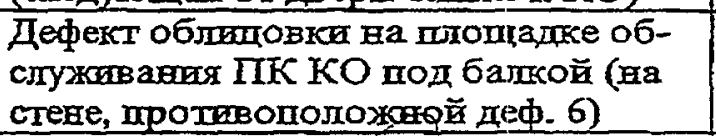 & $A-101 / 1$ & KAЭP & $\begin{array}{l}\text { до пу пука } \\
\text { блока }\end{array}$ & устранетіо \\
\hline 13. & $\begin{array}{l}\text { Поток воздуха из труббопровода } \\
\text { Ду } 150 \text { в попу под/КО }\end{array}$ & $A-101 / 1$ & 【UP & до наддуува & $\begin{array}{l}\text { привареніа } \\
\text { заглушика }\end{array}$ \\
\hline 14. & 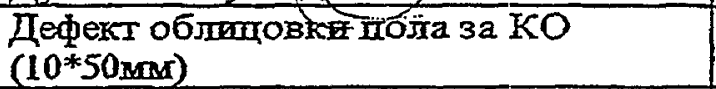 & $A-101 / 1$ & KAЭP & $\begin{array}{l}\text { до поска } \\
\text { блока }\end{array}$ & устранено \\
\hline 15. & $\begin{array}{l}\text { Дефект облатовка стены за КО па } \\
\text { уровне нагреватетей }\end{array}$ & $A-101 / 1$ & KAЭP & $\begin{array}{l}\text { до поска } \\
\text { Блока }\end{array}$ & yed \\
\hline 16. & 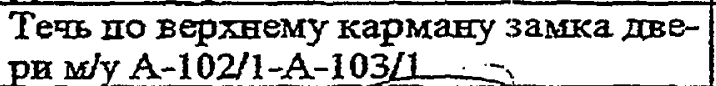 & $A-102 / 1$ & KAЭP & $\begin{array}{l}\text { до пуска } \\
\text { блока }\end{array}$ & устраневф \\
\hline 17. & 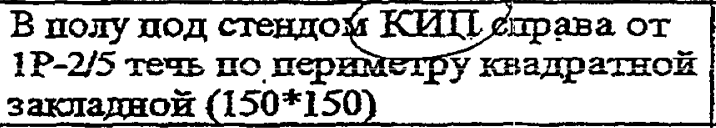 & $A-102 / 1$ & $\mathrm{KAOP}$ & $\begin{array}{l}\text { до пуска } \\
\text { блока }\end{array}$ & устранепіе \\
\hline 18. & 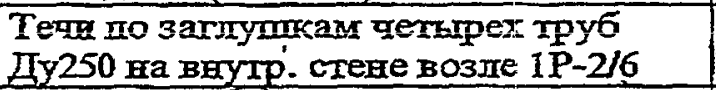 & $A-102 / 1$ & EAЭP & $\begin{array}{l}\text { ᄑо туска } \\
\text { блока }\end{array}$ & $\begin{array}{r}\text { устранено } \\
-\end{array}$ \\
\hline 19. & 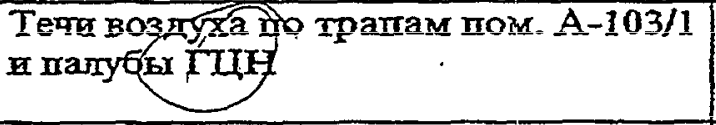 & $\begin{array}{l}A-102 / 1 \\
A-103 / 1\end{array}$ & IIIP & до ваддува & 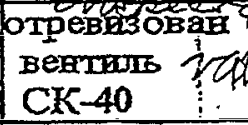 \\
\hline 20. & $\begin{array}{l}\text { Слабая теяв по фланшу подоколшат- } \\
\text { пому }\end{array}$ & & TTO & до падахува & $\begin{array}{l}\text { загерметв- } \\
\text { зировано } \\
\text { герметикома }\end{array}$ \\
\hline 21. & 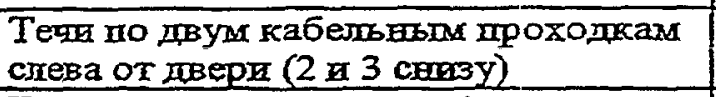 & A-103/1 & ЦTATX & $\begin{array}{l}\text { декабрь } \\
1996 r \text {. }\end{array}$ & устравено \\
\hline 22 & 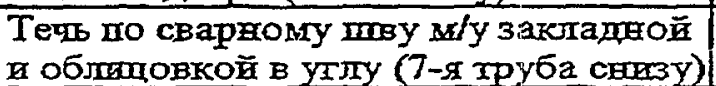 & $A-103 / 1$ & КАЭP & $\begin{array}{l}\text { до иу иука } \\
\text { блока }\end{array}$ & устранено \\
\hline 23. & Дефект облитовка на стене за 1 Р-1/3 & $A-102 / 1$ & KAЭP & $\begin{array}{l}\text { до пуека } \\
\text { блока }\end{array}$ & устравено \\
\hline
\end{tabular}




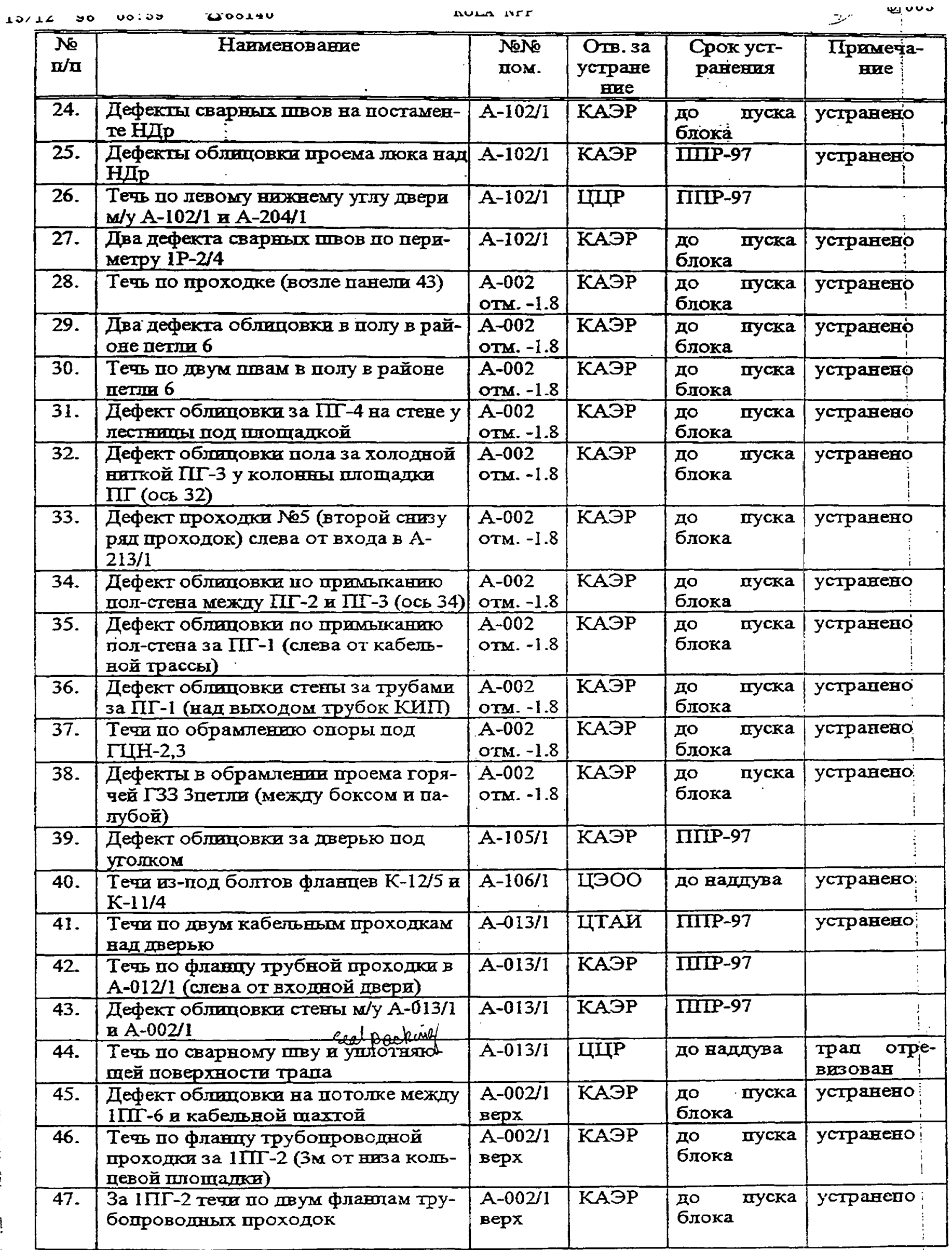




\begin{tabular}{|c|c|c|c|c|c|}
\hline$\Gamma^{2}$ & Haquденоваяте & $\begin{array}{l}\text { NoNe } \\
\text { rOM. }\end{array}$ & $\begin{array}{c}\text { Oxis. 3a } \\
\text { yexpare } \\
\text { Hue }\end{array}$ & $\begin{array}{l}\text { Cpok ycr- } \\
\text { pagerar }\end{array}$ & $\begin{array}{c}\text { Ippareqa:- } \\
\text { mae }\end{array}$ \\
\hline 48. & 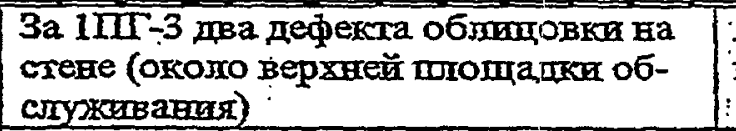 & $\begin{array}{l}\text { A }-002 / 1 \\
\text { Bepx }\end{array}$ & KAOP & до пуска & устранево \\
\hline 49. & $\begin{array}{l}\text { Два дефекта троходок на стене возле } \\
\text { КО }\end{array}$ & $A-101 / 1$ & КАЭР & $\begin{array}{l}\text { до пуска } \\
\text { блока }\end{array}$ & устранево \\
\hline 50. & 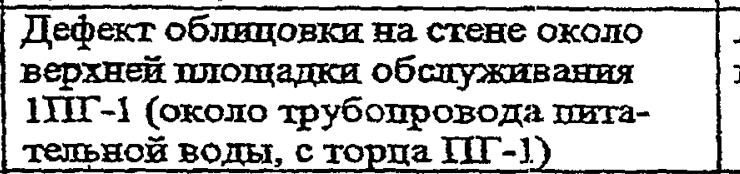 & $\begin{array}{l}\text { A-002/1 } \\
\text { вepx }\end{array}$ & KAYP & कо плота & устранево \\
\hline 51. & 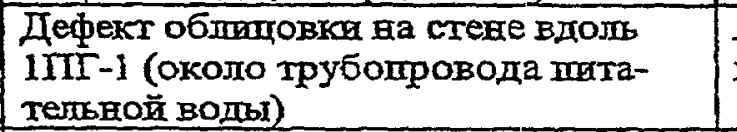 & $\begin{array}{l}A-002 / 1 \\
\text { sepx }\end{array}$ & KAЭP & $\begin{array}{l}\text { до пуска } \\
\text { блока }\end{array}$ & устравенф \\
\hline 52. & 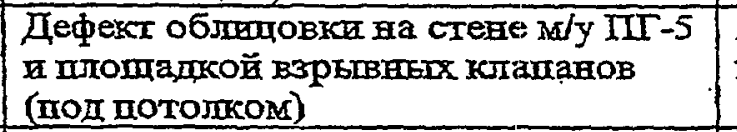 & $\begin{array}{l}\text { A-002/1 } \\
\text { Bepx }\end{array}$ & KAЭP & $\begin{array}{l}\text { до пуска } \\
\text { блока }\end{array}$ & yerp \\
\hline 53. & 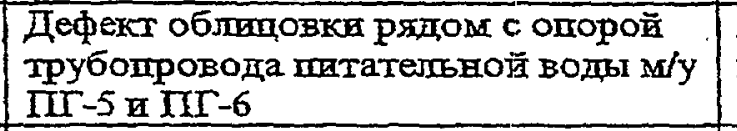 & $\begin{array}{l}\text { A-002/1 } \\
\text { Bepx }\end{array}$ & КАЭP & до пуока & yсxparenio \\
\hline 54. & $\begin{array}{l}\text { Дефект облбао овки над прохо дками } \\
\text { паропроводов на отм. } 14.0\end{array}$ & $\begin{array}{l}\text { A-002/1 } \\
\text { Bepx }\end{array}$ & KAЭP & \begin{tabular}{|l|} 
до пуска \\
блока
\end{tabular} & устранен \\
\hline 55. & $\begin{array}{l}\text { Дефект обламовки рядом с опорой } \\
\text { труботровода сприякиерной састемб } \\
\text { 3а Пт-6 }\end{array}$ & $\begin{array}{l}\text { A-002/1 } \\
\text { вepx }\end{array}$ & KAЭP & борока туска & устранево \\
\hline 56. & 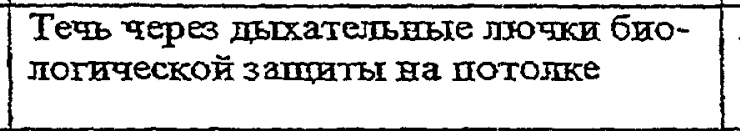 & $A-001 / 1$ & & IIIP-97 & 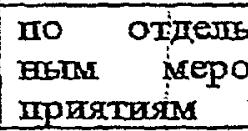 \\
\hline 57. & 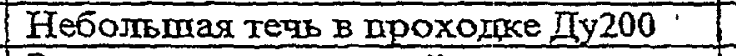 & $A-001 / 1$ & $\mathrm{KA} 3 \mathrm{P}$ & IIIIP-97 & \\
\hline 58. & $\begin{array}{l}\text { Заменить виет верхней кррематьеры } \\
\text { дверд }\end{array}$ & $A-004 / 1$ & ЦUP & до наддува & устранёво \\
\hline 59. & $\begin{array}{l}\text { Течи по флганам проходок IУ'- } \\
9,12,19\end{array}$ & $A-106 / 1$ & $\mathrm{KA} \ni \mathrm{P}$ & $\begin{array}{l}\text { деккабрь } \\
\text { 1996r. }\end{array}$ & \\
\hline 60. & 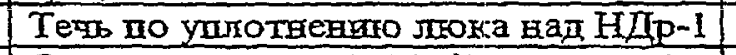 & $A-301$ & TTO & IIIP-97 & \\
\hline 61. & 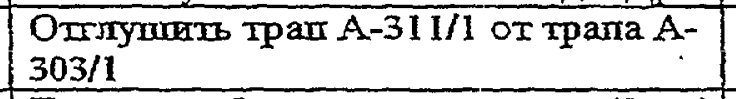 & $A-303 / 1$ & LUP & до наддува & 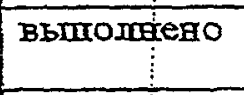 \\
\hline 62. & 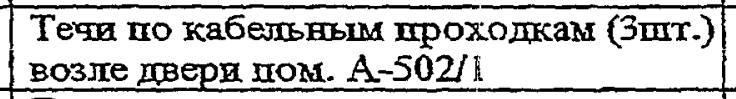 & $A-501 / 1$ & ITAK & IIIP-97 & устранено \\
\hline 63. & 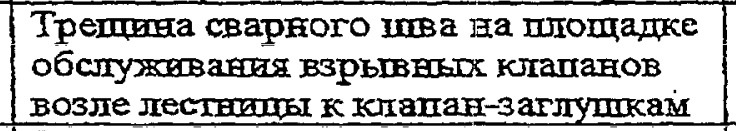 & $\begin{array}{l}\text { A-002/1 } \\
\text { вepx }\end{array}$ & $\mathrm{KA} 3 \mathrm{P}$ & $\begin{array}{l}\text { до } \\
\text { блока }\end{array}$ & устрапено \\
\hline 64. & $\begin{array}{l}\text { Течь из огверстия (10ма) ва верхней } \\
\text { плотадаке, левая стена }\end{array}$ & $A-207 / 1$ & KAЭP & ПIIP-97 & \\
\hline 65. & $\begin{array}{l}\text { Теть по кабельной трохо пке (4трубы) } \\
\text { за } 1 \text { ППГ } 4\end{array}$ & $A-002 / 1$ & UTAK & ПIIIP-97 & устранено. \\
\hline 66. & $\begin{array}{l}\text { Теть по кабепьной проходке (1труба) } \\
\text { (левал стена) }\end{array}$ & $A-104 / 1$ & IITAK & IIIIP-97 & устранево \\
\hline 67. & 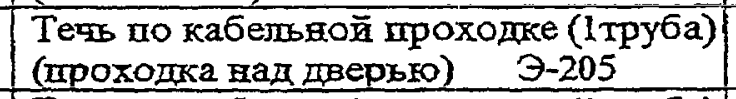 & $A-308 / 1$ & ITAX & IIIIP-97 & устратено \\
\hline 68. & 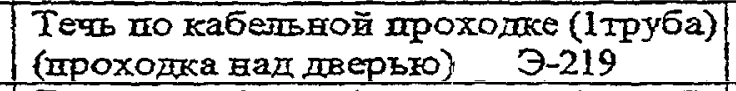 & $A-502 / 1$ & IUTAT & IIIIP-97 & устрандено \\
\hline 69. & 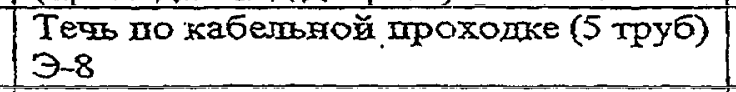 & $A-002 / 1$ & पTAH & חITP-97 & устрадтево \\
\hline 70. & $\begin{array}{l}\text { Тепь по кабельной прохолке } \\
\text { трубы) } 9-54\end{array}$ & $A-013 / 1$ & ITAK & IIIIP-97 & устравево \\
\hline
\end{tabular}




\begin{tabular}{|c|c|c|c|c|c|}
\hline $\begin{array}{l}N_{0} \\
\pi / n\end{array}$ & Hamменоваве & $\begin{array}{l}\text { NGNo } \\
\text { HOM. }\end{array}$ & $\begin{array}{c}\text { Oтв. 3a } \\
\text { yсrpaнe } \\
\text { mae }\end{array}$ & $\begin{array}{l}\text { Cpoк уст- } \\
\text { páegras } \\
:\end{array}$ & $\begin{array}{l}\text { Пpmága- } \\
\text { mad }\end{array}$ \\
\hline 71. & $\begin{array}{l}\text { Tечь по кабельной прохо пке (5 труб) } \\
\text { Э-7 }\end{array}$ & A-004/1 & UTATI & IIIIP-97 & устравево \\
\hline 72. & Течь по кабешьной проходке Э-6а & A-004/2 & ЦTAK & IIIIP-97 & устранено \\
\hline \multicolumn{6}{|c|}{ BБLABTEHO IPA AALIYBE } \\
\hline 1. & $\begin{array}{l}\text { Слабая тежњ по резервнњм кабель- } \\
\text { ньм проходкам (первая проходка от } \\
\text { входа с певой стороны в полу) }\end{array}$ & A-203/1 & ЦTAY & $\begin{array}{l}\text { sersaps } \\
1997 \mathrm{r} .\end{array}$ & устранено \\
\hline 2. & $\begin{array}{l}\text { Течь по кабепной проходке - } \\
2 \text { хрубы (слева на стеве напротыв } \\
\text { СК-9 ИВМ) }\end{array}$ & A-203/1 & ЦТАИ & $\begin{array}{l}\text { grварь } \\
\text { 1997ז. }\end{array}$ & устранево \\
\hline 3. & 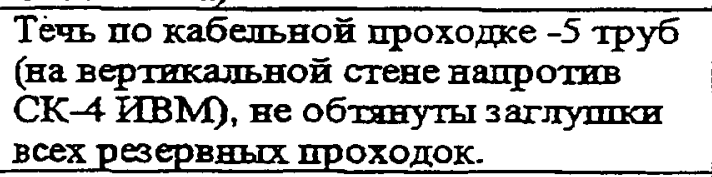 & A-203/1 & ЦТАИ & $\begin{array}{l}\text { grisaps } \\
1997 \mathrm{r} .\end{array}$ & устравено \\
\hline 4. & $\begin{array}{l}\text { Тепв по кабельной прохошке - } \\
13 \text { труб (ва вертикапвой стене ва- } \\
\text { против HZCK-6). }\end{array}$ & A-203/1 & UTAH & $\begin{array}{l}\text { grварь } \\
1997 \mathrm{r} .\end{array}$ & устравево \\
\hline 5. & $\begin{array}{l}\text { Tечs по резервной кабельной про- } \\
\text { ходке }\end{array}$ & $\mathrm{A}-008 / 1$ & ITAK & $\begin{array}{l}\text { gäварь } \\
1997 \mathrm{r} \text {. }\end{array}$ & yстранено \\
\hline 6. & $\begin{array}{l}\text { Течь по қабепьной шроходке (справа } \\
\text { вшжняя крайняя) }\end{array}$ & $A-008 / 2$ & ЧTAM & $\begin{array}{l}\text { gaвapb } \\
1997 \mathrm{r} \text {. }\end{array}$ & устранево \\
\hline 7. & $\begin{array}{l}\text { Течь по фланиу трубопроводвой } \\
\text { проходки из А-306/1 в А-502/1 }\end{array}$ & $A-502 / 1$ & KAЭP & $\begin{array}{l}\text { декабрь } \\
1996 \mathrm{r} \text {. }\end{array}$ & \\
\hline 8. & $\begin{array}{l}\text { Течи по фландам трубопроводов ПК } \\
\text { СУЗ }\end{array}$ & $A-108 / 1$ & KAЭP & $\begin{array}{l}\text { декабрь } \\
1996 \mathrm{r} \text {. }\end{array}$ & \\
\hline 9. & Нешлотность пюка вад НДр-1 & A-301 & TTO & ПIIP-97 & \\
\hline 10. & $\begin{array}{l}\text { Течь по кабельной проходке (вторая } \\
\text { по ходу) }\end{array}$ & $3-002 / 4$ & ЭЦ & ПIIP-97 & устранеңо \\
\hline 11. & $\begin{array}{l}\text { Тень по кабельной прохоцке } \\
\text { (постедняя) }\end{array}$ & $3-002 / 4$ & ЭЦ & $\Pi 11 P-97$ & устранево \\
\hline 12. & 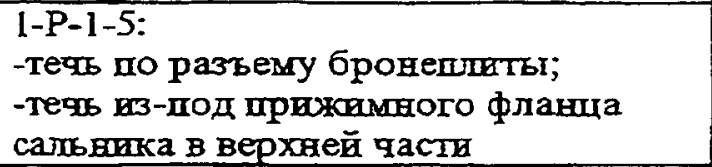 & $\mathrm{B}-005 / 1$ & ЦЭОО & ПIIP-97 & устранено \\
\hline 13. & 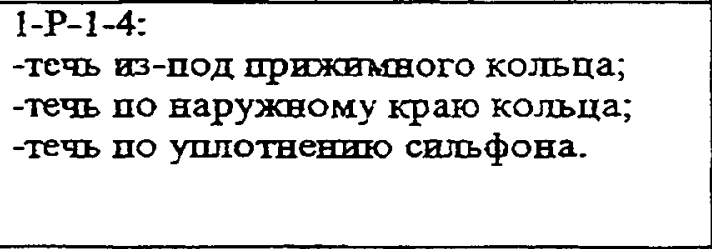 & $\mathrm{B}-005 / 1$ & ЦЭОO & $\begin{array}{l}\text { ПМР-97 } \\
\text { ППР-97 }\end{array}$ & $\begin{array}{l}\text { устранево в } \\
\text { ходе испи- } \\
\text { тантеи }\end{array}$ \\
\hline 14. & 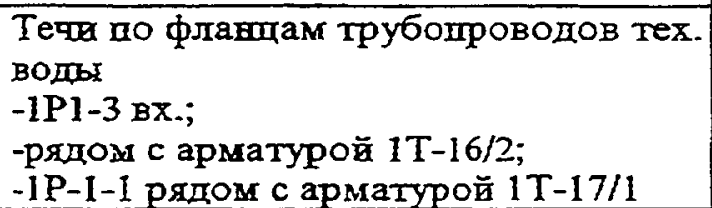 & B-005/1 & ЦЭОО & ПIगP-97 & устранево \\
\hline 15. & $\begin{array}{l}\text { Течь по уплотневиғо люка-лаза в воз- } \\
\text { духовод P-1 }\end{array}$ & $\mathrm{B}-004 / 1$ & ЦЭOO & ПएР-97 & 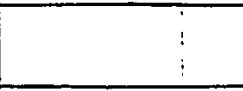 \\
\hline 16. & 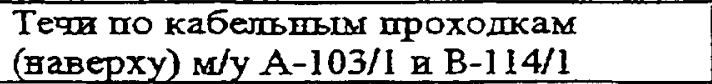 & B-114/1 & LTAK & $\begin{array}{l}\text { ятіварь } \\
1997 \text {. }_{\text {. }}\end{array}$ & устравено \\
\hline 17. & Тепь по флавщу трубы (слева) & $B-114 / 1$ & KAЭP & ППР-97 & ; \\
\hline 18. & $\begin{array}{l}\text { Тегя по кабетьным проходкам м/у A- } \\
004 / 2 \text { в } \mathrm{A}-014 / 1\end{array}$ & A-004/2 & ЧTAY & ПUா-97 & устранево \\
\hline
\end{tabular}




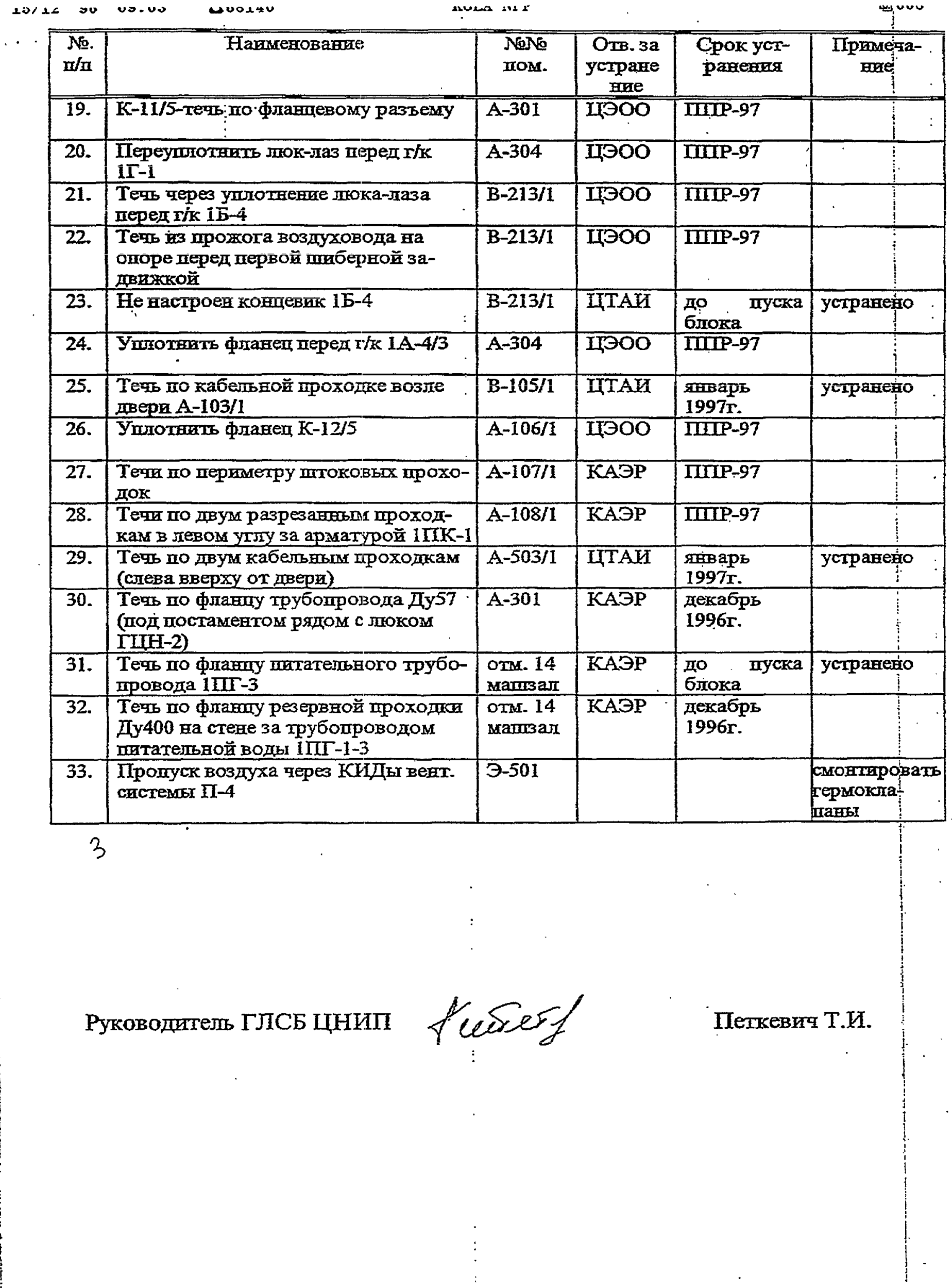




\section{ATTACHMENT 7}

Request for Additional Material for Leaktightness Improvements Kola Units 1, 2

(English and Russian) 


\begin{tabular}{|l|l|}
\hline To: Dr. George Greene & $\begin{array}{l}\text { From: Omel'shuk V.V. } \\
\text { Chief Engineer }\end{array}$ \\
\hline Company: & Telephone: \\
\hline Telephone:: & Fax: \\
\hline Fax: & $\begin{array}{l}\text { Date: } 10 / 16 / 96 \\
\text { Ident. No. 11/8-448 } \\
\text { No. Of Pages, including cover sheet: } 2\end{array}$ \\
\hline
\end{tabular}

Dear Mr. Greene!

During the past few years at the Kola Nuclear Power Plant a lot of work has been completed with regard to containment leak tightness. We are succesfully using materials and equipment made by USA companies, and supplied to the Kola NPP within the framework of the International Nuclear Safety Program. However, at this time, these materials have either finished ( Pefsarding gastets's? since the result of reconstructing the trap doors is requiring twice (2) the number of gaskets), or because their functional use has come to an end (which concerns sealants).

In order to successfully continue with our work on increasing containment leak-tightness of units 1, 2 I would like to request that you consider supplying the Kola NP.P within the framework of the International Nuclear Safety Program, with materials and equipment that is listed in the attachment to this Fax.

Attachment: materials and equipment that are required (necessary) for the continuation of work for containment leak-tightness at the Kola NPP.

With Respect

Chief Engineer

V.V. Omel'chuk

Translated by Helen Todosow

For G. Greene

Dec. 2, 1996 
Attachment 1.

Materials and equipment required by the Kola NPP for continuing work in containment ieak-tighness for Units 1,2

Unit 1.

\begin{tabular}{|c|c|c|}
\hline Item/name & Required amount & size/dimensions \\
\hline $\begin{array}{l}\text { 1.Rubber seals: } \\
\text { - for doors } \\
\text { - for hatches } \\
\text { - for hatches of the "central } \\
\text { air system(?)" } \\
\text { - for the reactor header/cap }\end{array}$ & $\begin{array}{l}100 \mathrm{~m} \\
500 \mathrm{~m} \\
100 \mathrm{~m} \\
25 \mathrm{~m}\end{array}$ & $\begin{array}{c}15 \times 50 \mathrm{~mm} \\
15 \times 30 \mathrm{~mm} \\
12 \times 12 \mathrm{~mm} \\
030 \mathrm{~mm}\end{array}$ \\
\hline $\begin{array}{l}\text { 2. Sealants; } \\
\text {-"carboline-163" } \\
-45 \mathrm{~V}\end{array}$ & $\begin{array}{l}50 \text { units/sets } \\
5 \text { units/sets }\end{array}$ & \\
\hline $\begin{array}{l}\text { 3. Hermetic valves for the } \\
\text { ventilation system. }\end{array}$ & $\begin{array}{l}2 \text { items } \\
2 \text { items } \\
2 \text { items } \\
16 \text { items }\end{array}$ & $\begin{array}{l}\text { Du } 1000(?) \\
\text { Du } 250(?) \\
\text { Du } 350(?) \\
\text { Du } 500(?)\end{array}$ \\
\hline
\end{tabular}

\section{Unit 2}

\begin{tabular}{|l|c|c|}
\hline Item /name & Required amount & Dimensions/size \\
\hline 1. Rubber seals: & $50 \mathrm{~m}$ & $15 \times 50 \mathrm{~mm}$ \\
- for doors & $250 \mathrm{~m}$ & $15 \times 30 \mathrm{~mm}$ \\
- for hatches & $50 \mathrm{~m}$ & $12 \times 12 \mathrm{~mm}$ \\
- for hatches of the "central & $25 \mathrm{~m}$ & $030 \mathrm{~mm}$ \\
air system(?)" & & \\
\hline 2. Sealants; & 50 units/sets & \\
- Carboline-163 (?) & 5 units/sets & \\
$-45 \mathrm{~V}$ & & \\
\hline
\end{tabular}




\begin{tabular}{|c|c|c|}
\hline $\begin{array}{l}\text { 3. Manual drive for hermetic } \\
\text { valves with pneumatic drives } \\
\text { for the ventilation system "P- } \\
4 \text { " assembled at Unit } 2 \text { during } \\
\text { planned outage }-96 \text {. }\end{array}$ & 2 items & Du 1000 \\
\hline
\end{tabular}

Director of CNEP

Paradnikov, G.S. 


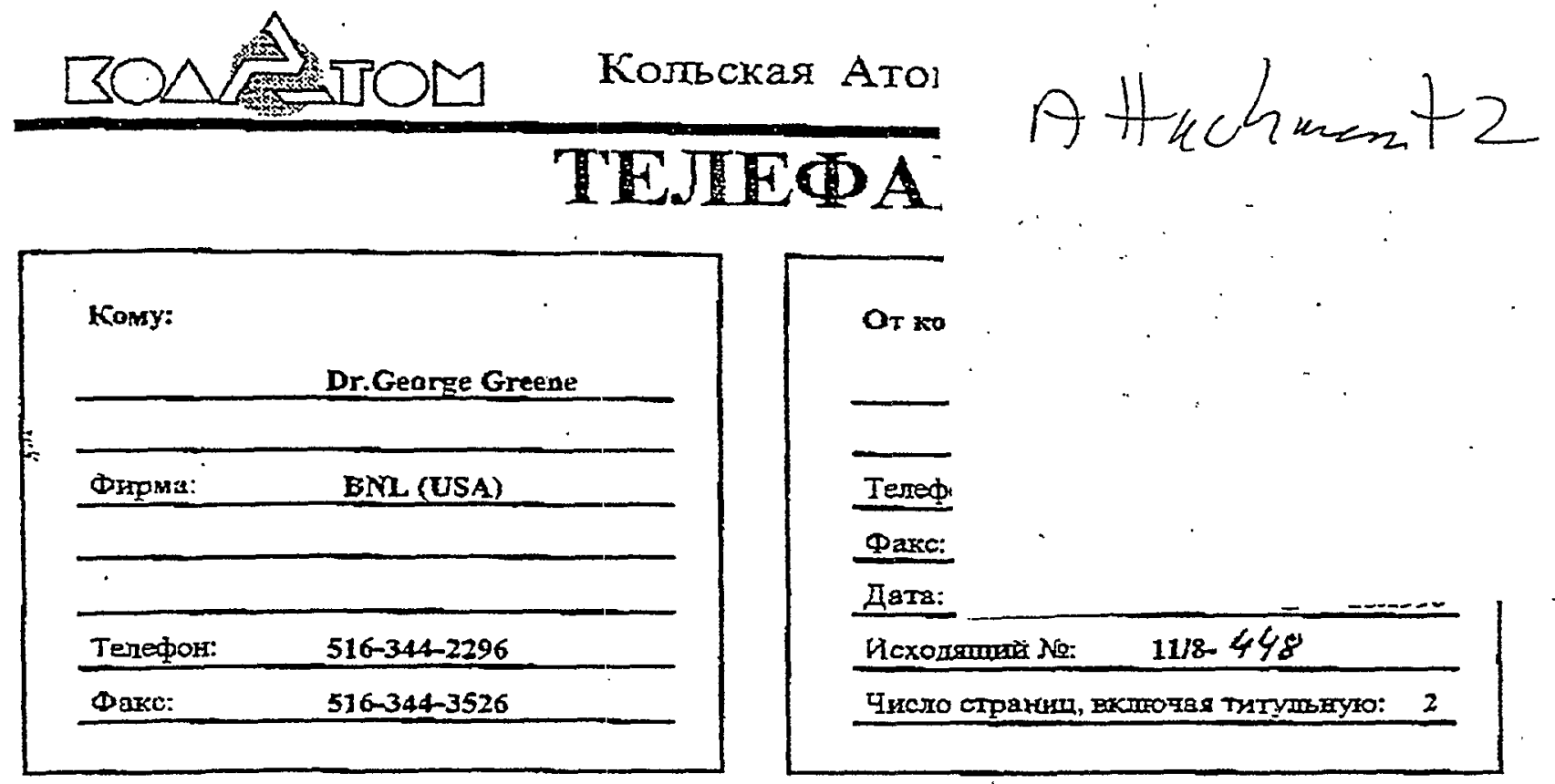

Уважаемьй Г. Грин!

В последние годы на Кольской АЭС вьмолнен большой объем работ по герметизашии помешений гермообъема. С успехом применяются материалы и оборудование производства компаний США, поставленные на Кольскую АЭС в рамсках Мехдународной Программы Ядерной Безопасности. Однако к настоящему моменту эти материалы либо закондились (касается резиновыт уплотнений, т.к. в результате реконструкцин люоков расход резиновьх уплотненй у увеличивается в 2 раза), либо закончился их срок годности (касается герметиков).

Дпя успешного продолжения работ по повьппению герметичности конфайнментов блоков 1,2 прошу Вас рассмотреть вопрос о поставке на Кольскую АЭС в рамках Международной Программы Ядерной Безопасности материалов и оборудования, представленных в приложения к настоящему факсу.

Приложение: материаты и оборудование, необходимыт Комьскй АЭС для продолжения работ по герметизацин конфайнмента.

C уважением

Главныг инженер

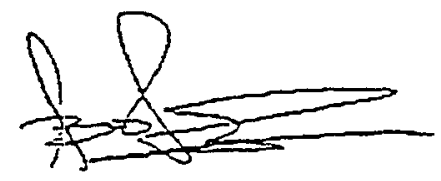

Омельуук В.В.

Пегкевня, 29-71

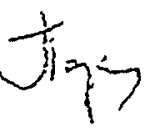


Приложенде 1.

Материалы и оборудование, необходнмые Кольской АЭС лля продолхения работ по герметизации конфайнмента блоков 1,2

Блок 1.

\begin{tabular}{|c|c|c|}
\hline Нвименование & Необходимое количество & Рaзмер \\
\hline \multirow{5}{*}{$\begin{array}{l}\text { 1. Резиновье уплотнения: } \\
\text { - для пверей } \\
\text { - для лпоков } \\
\text { - для люков СВО-1 } \\
\text { - для колпака реактора }\end{array}$} & & \\
\hline & $100_{M}$ & $15 \times 50 \mathrm{MM}$ \\
\hline & $500 \mathrm{M}$ & $15 \times 30 \mathrm{mM}$ \\
\hline & $100 \mathrm{M}$ & $12 \times 12 \mathrm{Nax}$ \\
\hline & $25 \mathrm{M}$ & $\varnothing 30 \mathrm{MM}$ \\
\hline \multirow{3}{*}{$\begin{array}{l}\text { 2. Герметики: } \\
\text { - карболайн-163 } \\
-45 B\end{array}$} & & \\
\hline & 50 kommлектов & \\
\hline & 5 кOMmITekroB & \\
\hline \multirow{4}{*}{$\begin{array}{l}\text { 3. Гермоклапаны систем } \\
\text { вентилапия. }\end{array}$} & $2 \mathrm{mT}$. & Ду1000 \\
\hline & 2IIIT. & BY250 \\
\hline & $2 \pi r r$. & Дy350 \\
\hline & $16 \mathrm{wT}$. & Дy500 \\
\hline
\end{tabular}

Бrok 2

\begin{tabular}{|c|c|c|}
\hline Нанменованне & Необходимое количество & Рaзмep \\
\hline \multirow{5}{*}{$\begin{array}{l}\text { 1. Резиновые уплотнения: } \\
\text { - для дверей } \\
\text { - для люков } \\
\text { - для пюков СВО-1 } \\
\text { - для колпака реактора }\end{array}$} & & \\
\hline & $50_{M}$ & $15 \times 50 \mathrm{MM}$ \\
\hline & $250 \mathrm{M}$ & $15 \times 30 \mathrm{MM}$ \\
\hline & $50_{M}$ & $12 \times 12 \times M$ \\
\hline & $25 M$ & $\varnothing 30 \mathrm{NM}$ \\
\hline \multirow{3}{*}{$\begin{array}{l}\text { 2. Герметики: } \\
\text { - кар5олайн-163 } \\
\text { - 45В } \\
\end{array}$} & & \\
\hline & 50 комплектов & \\
\hline & 5 комплектов & \\
\hline $\begin{array}{l}\text { 3. Ручной привод ала гер- } \\
\text { моклапанов с пневмоприво- } \\
\text { дом вентиляционной систе- } \\
\text { мы П-4. смонтнрованных на } \\
\text { блоке } 2 \text { в ППР-96. }\end{array}$ & $2 \mathrm{wr}$ & $\overline{A y} 1000$ \\
\hline
\end{tabular}

Науяльник ЦНИП

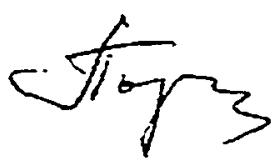

Парадников Г.С. 


\section{ATTACHMENT 8}

Request from Kola NPP to B\&R for Manual Isolation Valves Kola Unit 2

(English and Russian) 


\section{TELE-FAX}

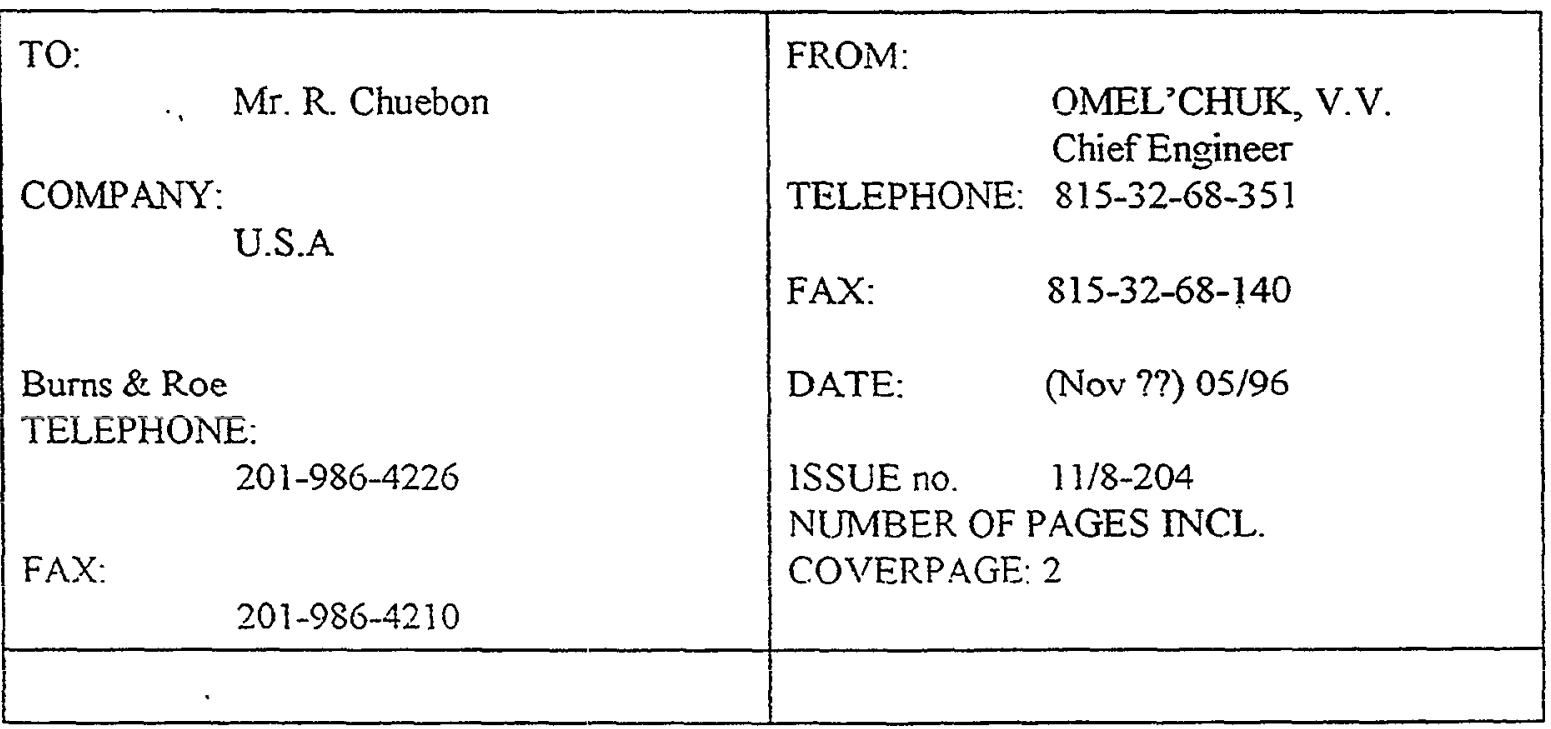

Concerning additional manual drives for pneumatically controlled hermetic valves for the Kola NPP, unit 2.

Dear Mr. Chuebon;

During the final phase of the contract between the company "Bums \& Roe" and "Enertech" and in addition between "Burns \& Roe" and the Kola NPP, and during the development of the technical specifications for hermetic valves, a detailed description of the operation of the valves was not available, in order to be able to unambiguously determine the functioning of the valves under various conditions. In addition, specialist at the Kola NPP, were not previously familiar with the principles of operation of the pneumatic drives of the hermetic valves (pneumatically controlled hermetic valves) made in the USA.

After receiving and carefully analyzing the complete collection of documents, concerning the functioning of the hermetic valves with pneumatic drives (pneumatically driven hermetic valves), it was determined that in the case of a unanticipated (unauthorized) cut-off of pressurized air-flow or electrical current to the pneumatic drive, the valves close-shut, and it is impossible to open them.

According to the plans for Unit 2 of the Kola NPP the air-flow into the pressurized system during 
plant operations and during planned outages of the unit is accomplished only by the ventilation of the $\mathrm{P}-4$ system, where the given hermetic valves are being installed. The shut-off of air flow to the steam generator "box" (room) during various operating conditions of the unit is unacceptable for the following reasons:

1. During power operations of the unit, the closing of valves (even only one out of two) during non-accident situations, and the inability of opening them, results in the full shut-off of air supply to the pressure system (?), and as a result, leads to the increase in temperature in the steam generator "box" (hall/room) and on the deck of the main circulating pumps, which in turn, leads to the necessary shutdown of the unit.

2. The shut-off of air supply to the steam generator in the case of the closing of hermetic valves during a planned outage of the unit, leads to a worsening of working conditions for plant personnel (increased temperatures, humidity, a worsening of the radiation conditions) in the steam generator hall.

As a consequence of the above, it becomes imperative to have a mechanism for manually opening the valves in the event of their unanticipated closure during non-accident situations.

Based on the information from Bums \& Roe representatives and from brochures from "Enertech," it turns out that there are manual drives for hermetic valves, which can be retrofitted to the already installed hermetic valves.

I ask that you consider the installation of two manual drives for hermetic valves with pneumatic drives for system P-4 of unit 2 of the Kola NPP, as a form of technical assistance within the framework of the Lisbon Initiative.

With Respect,

Chief Engineer

V.V. Omel'chuk 


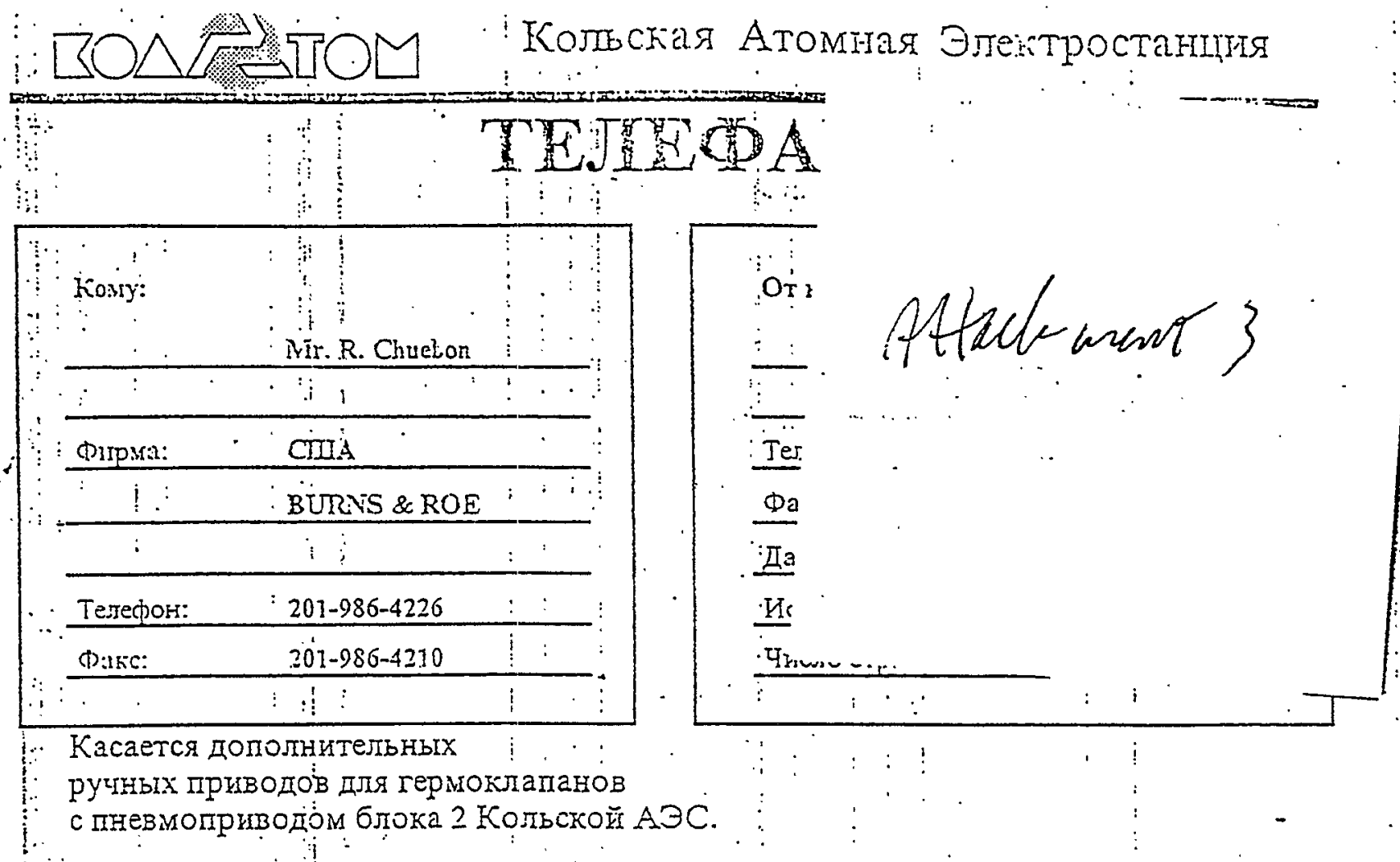

Уважземьй г. Шубен!

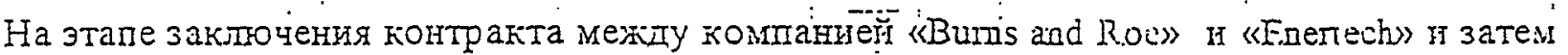
между «Burns and Roe» и Кольской АЭС ил во еремя разработки технтческой специфинкацин Iпо гермоклапанам не хватало подробного отисания работы қлапанов, чтобы отнозначно оценить работу клапана в разлтчныт режнлмах. Крсме того, спедиалпсты КАЭС не былм ранее знакомы с принципами 'работы пғевмоприводов термоклипанов производства CUIA.

После получения и детального аналнза полного комплекта гокументое. касалошіхсд работы гермоклапанов с пневмоприводом, было выявлено, что в стучае несанционированного прекращения подачи сжатого воздуха или электропнтания на пнев:1оприводы клапаны закрываются и их невозможно открыть.

. По проекту на блоке 2 КАЭС приток воздуха в гермообъемп пти работе блока на мощности и во время планового ремонта (ППР) блока осуществляетял только вент. системой П-4, на которой устанавливаются данные термоклапаны. Прекрашение 'подачли воздуха в бокс парогенераторов (III) при различных режимах работы блока недопустимо по следуюшим причинам:

1. при работе блока на мошности закрытие клапана (даже одесго из Іеух) в неаварийной ситуации и невозможность его открытля приводит $\mathrm{K}$ долнолгу прекрашеннио подай ия притонного воздуха в гермообъем и, как следствие, к росту температуры в боксе ПГ. иі на ппалубе главных чиркуляционнытх насосов (ТLH), что в своюо очередь приведет к несбходимости останова блока;

2. прекрапнейе подачи приточного воздуха в бокс ПГ в случае закрытия гермоктапана Ђо времл ППР блока приводит к ухудшению условий работы персонала (повьпненіно тем-

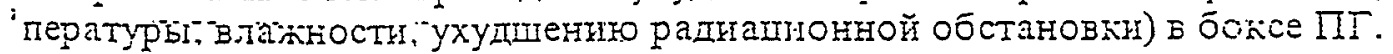

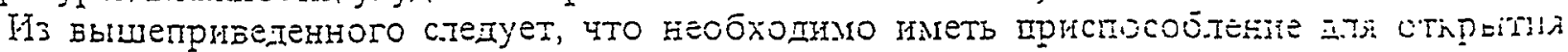

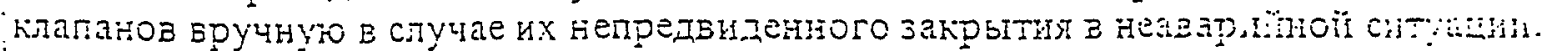

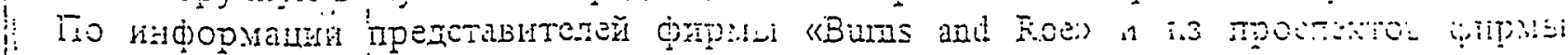

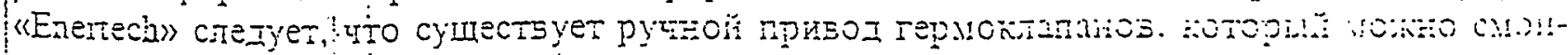

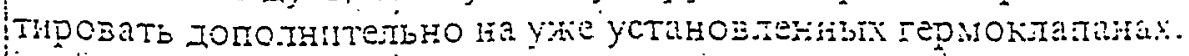

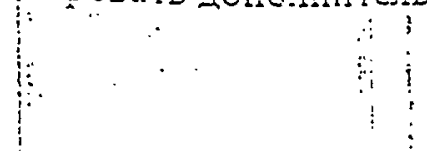




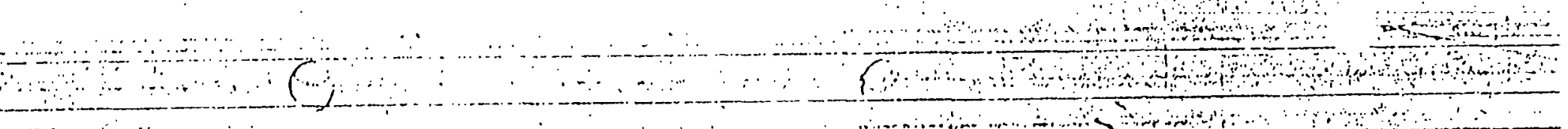

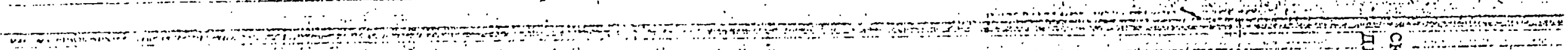

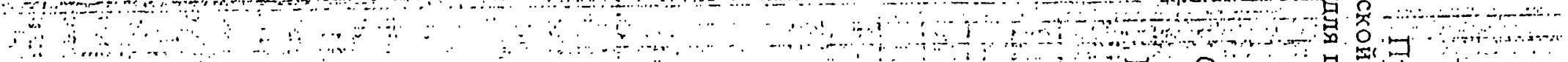
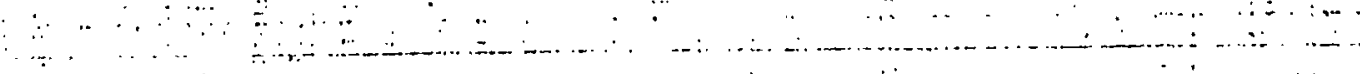

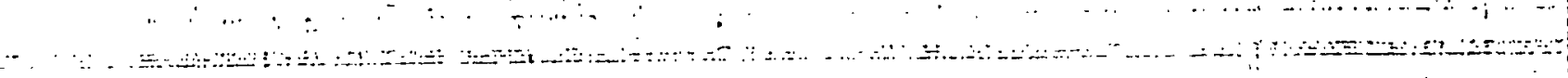

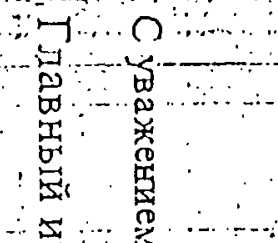

4 .

3.

з 잉

定

E

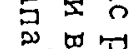

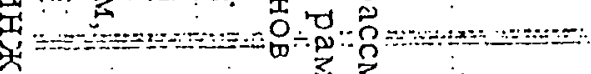
길.

品曷

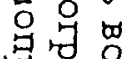

and

and $4+4$

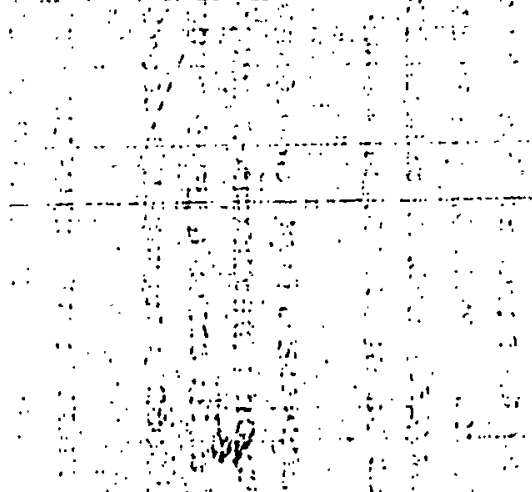

$3 \%$

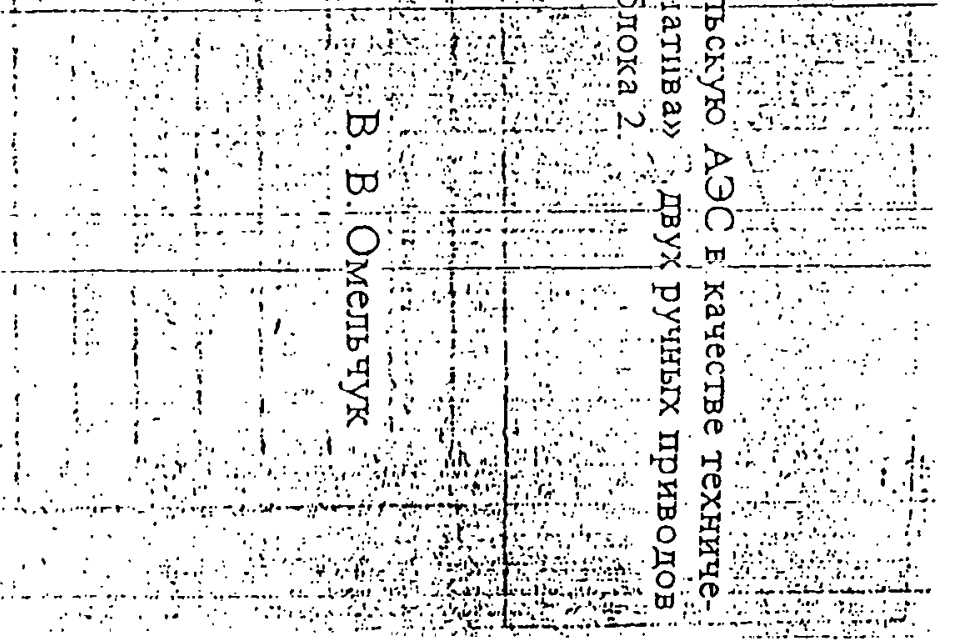

